\title{
El Congreso de los Estados Unidos. DESDE SUS INIIIOS HASTA LA CRISIS DE 1930
}

\section{Alberto B. Bianchi}

\author{
Universidad Austral. Universidad Católica Argentina \\ ab@bgcv.com.ar
}

Recibido: 02/08/2021

Aprobado: 24/10/2021

\section{Resumen}

Este trabajo resume la historia del Congreso de los Estados Unidos desde sus orígenes coloniales hasta la crisis económica de 1930. Se analiza en primer lugar cómo se diseñó el Congreso en la Convención Constituyente, las luchas internas que se produjeron en esta que dieron origen a un Congreso bicameral y cómo fue interpretado inicialmente el texto constitucional en El Federalista. Luego, la historia propiamente dicha del Congreso -desde su instalación en 1789 hasta la crisis de 1930- está dividida en cinco capítulos que intentan poner de manifiesto la impronta política existente en el Congreso en cada uno de ellos. Se muestra, así, la manera en la que cada partido ha influido en el Congreso según las mayorías que cada uno de ellos ha tenido alternativamente. Se destaca también la sanción de algunas leyes fundamentales, las enmiendas constitucionales que han influido en el diseño o formación del Congreso y se mencionan las figuras de los principales líderes políticos que han predominado en ambas cámaras en cada época. Asimismo, se muestra la evolución, conformación y crecimiento de cada cámara a lo largo del siglo y medio que abarca este estudio, a partir de las circunstancias políticas y económicas que se han presentado en cada época.

Palabras clave: Constitución, Convención Constitucional, Congreso, Speaker, Cámara de Representantes, Senado, partidos políticos, líderes políticos, comisiones, reglamentos, distribución distrital, legislador, elección, filibuster.

\section{The United States Congress. From the Beginnings to the 1930's Crisis}

\author{
Abstract \\ This paper contains a summarized history of the U.S. Congress, from its colonial inception \\ until the economic crisis of 1930. It analyses first how Congress was designed at the Constitu-
}


tional Convention, the internal disagreements within the Convention that eventually gave rise to a bicameral Congress, and the manner how the Constitution was initially interpreted at The Federalist. Then, the history of Congress itself, from its creation in 1789 until the economic crisis of 1930, has been divided into five chapters designed to reflect the political influences prevailing in Congress at each such stage. This structure shows the manner how Congress has been influenced by each political party, depending on the majorities held by each at different times. Additionally, reference is made to some fundamental laws, the constitutional amendments that have influenced the design or structure of Congress, as well as some prominent political leaders from both Chambers of Congress at different times in history. This paper also includes a description of the evolution, structure and growth of each Chamber in the 150-year period covered here, in line with the political and economic circumstances prevailing at different times.

Key words: Constitution, Constitutional Convention, Congress, Speaker, House Senate, political parties, political leaders, committee, rules, apportionment, legislator, election, filibuster.

Well, Doctor, what have we got - a Republic or a Monarchy? Benjamin Franklin: A Republic, if you can keep it.

\section{Índice}

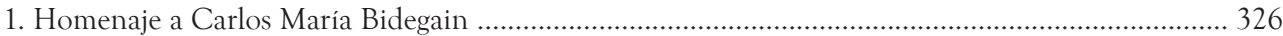

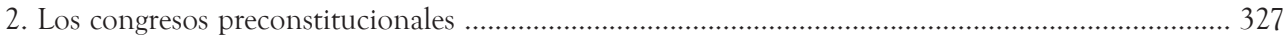

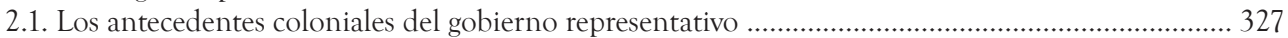

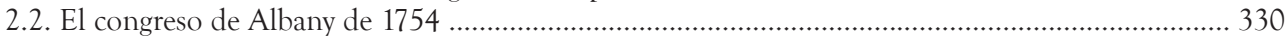

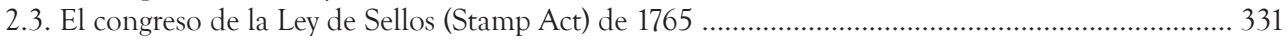

2.4. El primer Congreso Continental ............................................................................................. 332

2.5. El Segundo Congreso Continental, los Artículos de la Confederación y el Congreso

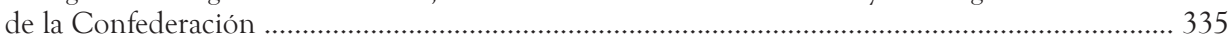

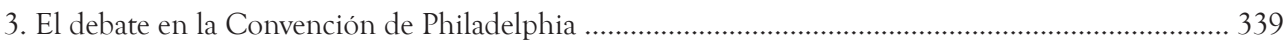

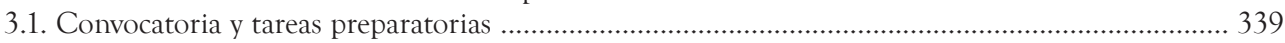

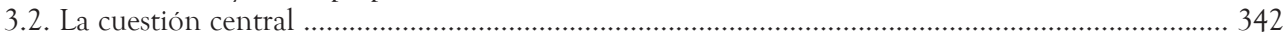

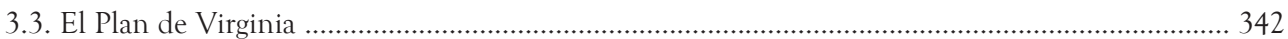

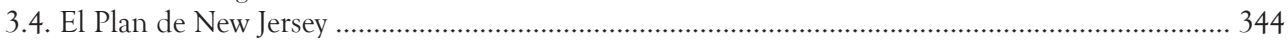

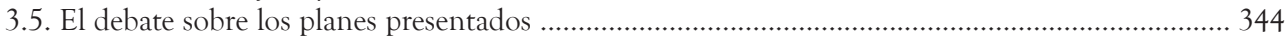

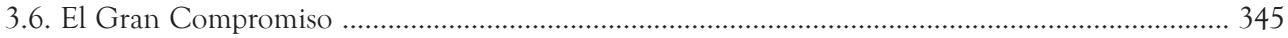

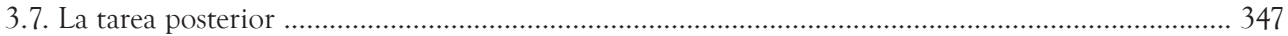

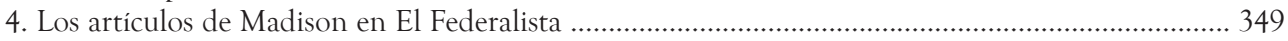

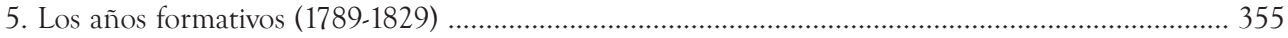

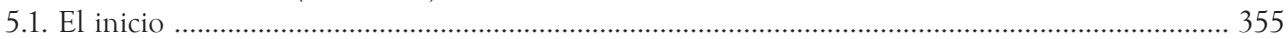

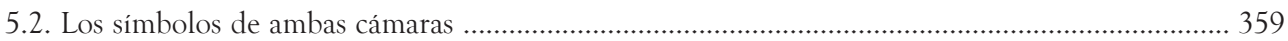

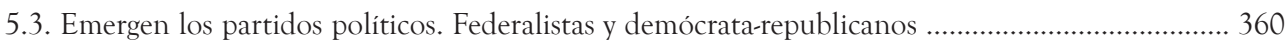

5.4. El reparto del poder entre el Ejecutivo y el Congreso ..................................................................... 361 


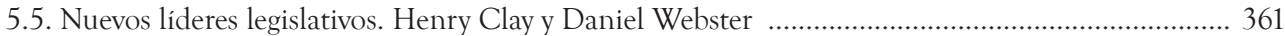

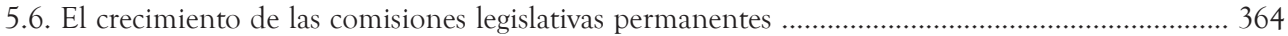

5.7. La Corte Suprema colabora para fortalecer al Congreso ............................................................ 365

5.8. La elección de 1824 y el nacimiento del Partido Demócrata ............................................................. 366

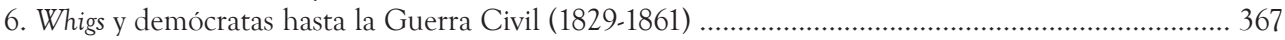

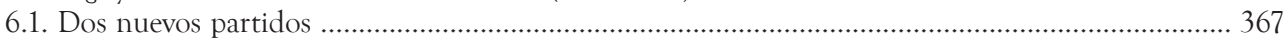

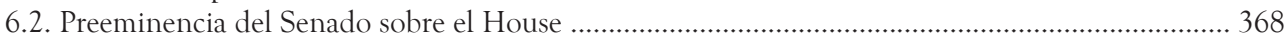

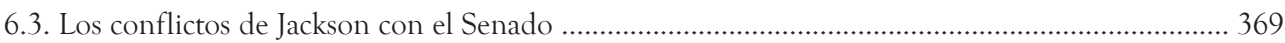

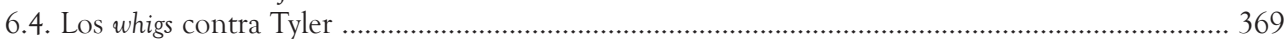

6.5. Los acuerdos legislativos sobre la distribución geográfica de la esclavitud ...................................... 370

6.6. Las contiendas en el House por la designación del Speaker .......................................................... 372

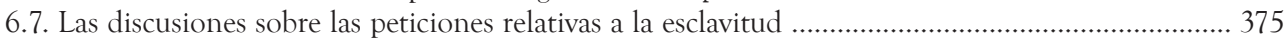

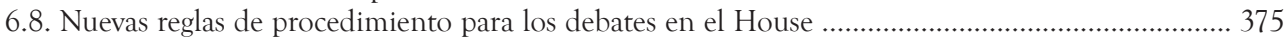

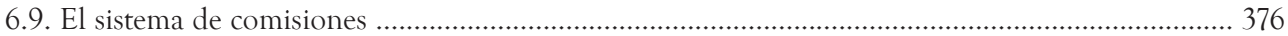

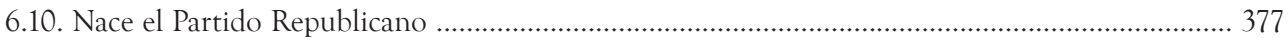

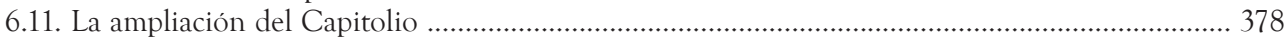

7. La Guerra Civil y la Reconstrucción (1861-1877) .................................................................................. 379

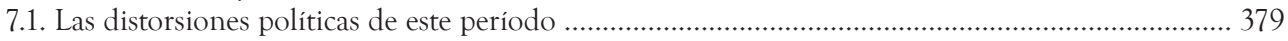

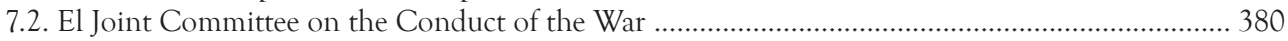

7.3. Los republicanos radicales y sus conflictos con Andrew Johnson ............................................... 381

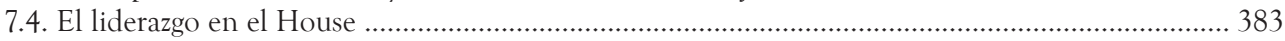

7.5. El Joint Committee on Reconstruction y la legislación derivada de la Guerra Civil ..................... 383

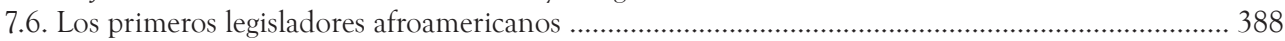

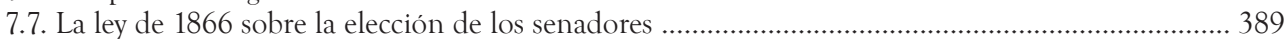

7.8. La elección presidencial de 1876, el Compromiso de 1877 y el fin de la Reconstrucción .............. 390

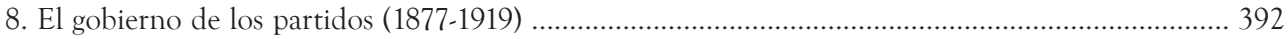

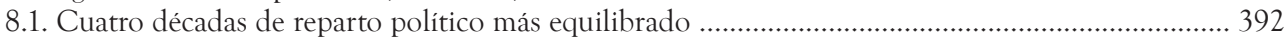

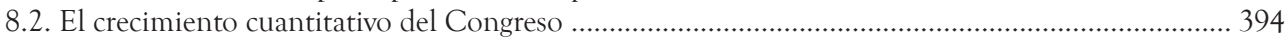

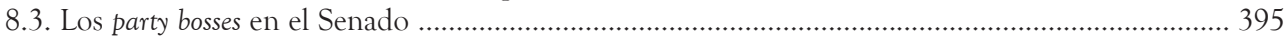

8.4. La práctica del filibuster en el Senado y el Cloture Rule ............................................................... 397

8.5. El caso Kilbourn v. Thompson y la revisión de las investigaciones del Congreso ............................... 399

8.6. La centralización del poder del Speaker. Thomas B. Reed y Joseph G. Cannon ............................. 400

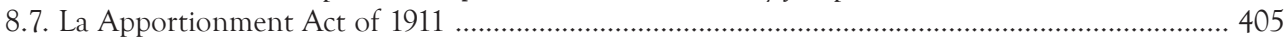

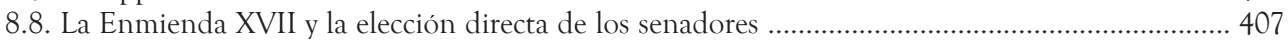

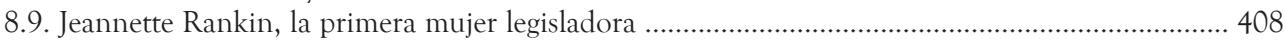

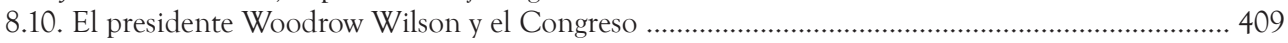

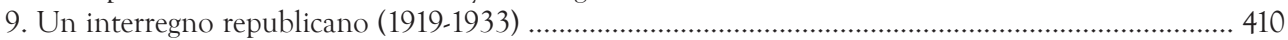

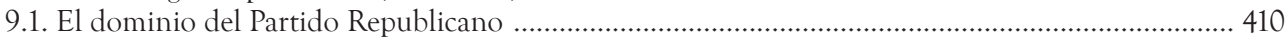

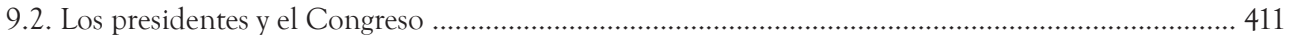

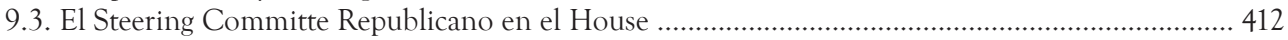

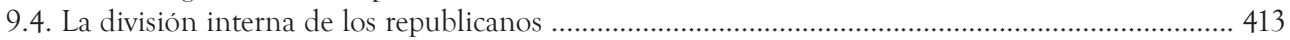

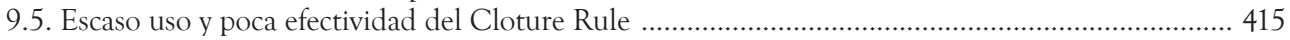

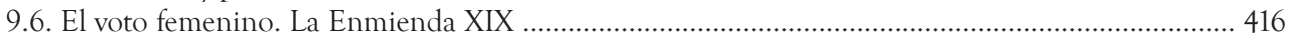

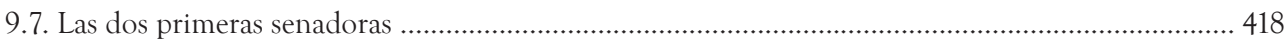

9.8. La Corte Suprema fortifica el poder de las comisiones legislativas de investigación ..................... 419

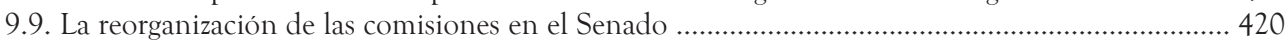

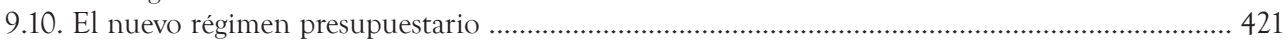

9.11. El debate sobre el aumento y redistribución de las bancas en el House. La Permanent

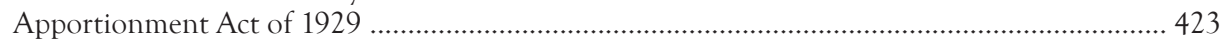

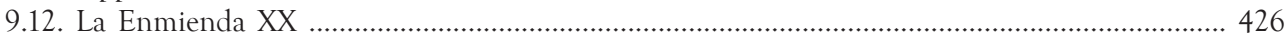

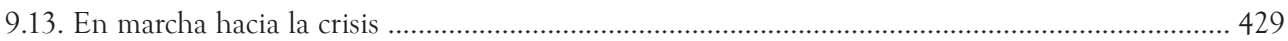

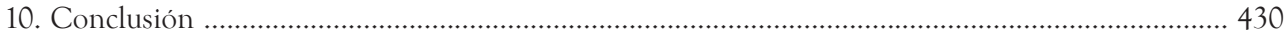




\section{Homenaje a Carlos María Bidegain}

En 1950, Carlos María Bidegain publicó una obra extraordinaria sobre el Congreso de los Estados Unidos. Fue su tesis doctoral, un trabajo de juventud que daba testimonio de la temprana madurez intelectual de su autor. Su extensión y profundidad excedía en mucho los alcances de una investigación de ese tipo, tal como señaló con razón Linares Quintana al prologarla. Laureada con el premio Montes de Oca a la mejor tesis de derecho constitucional y recomendada al Premio Facultad, desde entonces no se ha vuelto a escribir sobre este tema en nuestro país, al menos en forma orgánica y con tal intensidad.

Me ha parecido por ello de toda justicia, al comenzar este estudio, rendir un breve, pero muy sincero y sentido, homenaje al trabajo y a su autor, que ha sido uno de los grandes constitucionalistas argentinos. ${ }^{1}$ En sus Palabras Preliminares, Bidegain dice que "los propósitos y el esfuerzo han sido considerablemente superiores al resultado que queda expuesto", pero ello no es más que una muestra de su proverbial humildad y sencillez, dos notas que lo caracterizaban. Si bien tuve pocas oportunidades de tratarlo personalmente, lo que lamento, no me quedan dudas de que era una auténtica persona de bien y un jurista eximio.

Pasadas siete décadas de su publicación, la tesis de Bidegain -un verdadero tratado, como lo calificó su prologuista- sigue siendo una obra sin dudas relevante por su erudición y claridad, cuya consulta al estudiar el Congreso de los Estados Unidos es indispensable todavía para el mundo de habla hispana. Es por ello que con ese trabajo deseo cumplir -dentro de mis posibilidades y limitaciones- con la exhortación que Bidegain formuló en sus Palabras Preliminares: "Estimular la realización de estudios de derecho parlamentario en nuestro país”.

1 Nacido en Buenos Aires en 1916, se graduó de abogado en la Facultad de Derecho y Ciencias Sociales de la Universidad de Buenos Aires en 1938 y de doctor en Jurisprudencia en la misma Universidad en 1950. Fue también Master of Laws in Comparative Law, graduado "Magna cum Lauda" en el Law Institute of The Americas, SMU, Dallas, Texas (1954-1955). Fue procurador del Tesoro de la Nación (1960-1962) y profesor titular de Derecho Constitucional en la Universidad Católica Argentina (1964-1984). Fue miembro de número de la Academia Nacional de Ciencias Morales y Políticas y de la Academia Nacional de Derecho y Ciencias Sociales y miembro correspondiente de la Real Academia de Ciencias Morales y Políticas de España y de la Academia Chilena de Ciencias Sociales, Políticas y Morales. En 2006 recibió el Premio Konex. Su obra es extensa, señalo tan solo, además de su estudio sobre el Congreso de los Estados Unidos, el Curso de Derecho Constitucional en cinco volúmenes, cuya última edición (2001) fue preparada en colaboración con los profesores Eugenio L. Palazzo, Orlando Gallo, Roberto Punte y Guillermo C. Schinelli. Falleció en septiembre de 2016, cuando ya había cumplido 101 años. 


\section{Los congresos preconstitucionales}

\subsection{Los antecedentes coloniales del gobierno representativo}

A diferencia de la América española, donde la organización colonial era rígida, uniforme y muy estructurada, ${ }^{2}$ la Corona británica no tenía un sistema de gobierno uniforme para sus colonias y muchas de ellas nacieron, a lo largo del siglo XVII, como una iniciativa privada de naturaleza comercial, como Virginia, o bien tuvieron como origen la llegada de emigrados religiosos, como Massachusetts. Cada una de ellas tuvo, como acta de nacimiento formal, una carta real otorgada en diferentes momentos, pero en modo alguno este conglomerado colonial constituyó una unidad política, sino más bien un grupo de emprendimientos independientes, de variado tipo, desarrollados inicialmente por particulares bajo reglas propias. Algunas de ellas, hacia fines del siglo XVII y comienzos del XVIII, se convirtieron formalmente en colonias reales, otras permanecieron como colonias particulares hasta la Independencia. ${ }^{3}$

No entraré en los detalles históricos de la fundación y desarrollo de cada colonia, pues ello es ajeno a este trabajo. Por lo demás, la literatura sobre este tema es muy abundante. Uno de los primeros en exponerlo fue Joseph Story en sus Commentaries... ${ }^{4}$ Sin embargo, es importante tener presente que en todas las colonias existía alguna forma, aunque rudimentaria, de gobierno representativo. ${ }^{5}$

Story -siguiendo a Blackstone (1 Bl Comm 108)- clasifica a las colonias en tres grupos: (a) Gobiernos o establecimientos provinciales; (b) Gobiernos de propietarios (propietary governments); y (c) Gobiernos de la carta real (charter governments). En las primeras, el rey designaba como autoridad ejecutiva a un gobernador, denominado "capitán general”, quien recibía una comisión real y era el representante del soberano en la colonia. La comisión real incluía, entre otras previsiones, la de convocar a una asamblea compuesta de dos estamentos: el del gobernador y su consejo y el de los representantes de los propietarios de

2 Basta pensar que la Corona española tenía órganos de gobierno específico para todo el Gobierno colonial, como el Consejo de Indias o la Casa de Contratación de Sevilla, creados a comienzos del siglo XVI para asesorar políticamente al rey y controlar el comercio, respectivamente. Sumado a ello, toda la legislación indiana estaba recopilada y ordenada en verdaderos códigos, como fueron la Recopilación de 1680 y la Novísima Recopilación de 1805.

3 En el Anexo I (p. 433) explico brevemente el origen histórico de algunas de ellas.

4 Vid. Story (1858, caps. I-XVII).

5 Coincido con Bidegain (1950) en que "[l]a herencia política inglesa y las tempranas prácticas del régimen representativo contenían en potencia los elementos básicos sobre los que habría de edificarse la actual democracia norteamericana" (p. 20, nota al pie 1), aunque también tiene razón este autor en señalar que lejos estaba por entonces la existencia de un régimen democrático con los estándares de hoy día, pues la esclavitud era una institución legal y el derecho de voto era un privilegio de muy pocos. 
tierras y granjeros. Estas asambleas tenían poder para legislar en asuntos locales, sus leyes u ordenanzas no podían contradecir las leyes inglesas y estaban sujetas a la aprobación de la Corona. ${ }^{6}$ Dentro de esta categoría, al momento de producirse la revolución, existían 7 colonias: New Hampshire, New York, New Jersey, Virginia, North Carolina, South Carolina y Georgia. En el segundo grupo, el de los Gobiernos de propietarios (propietary goverments), un individuo particular recibía de la Corona una concesión para administrar la colonia. Este designaba al gobernador de la colonia y convocaba a las asambleas legislativas. Las colonias organizadas bajo esta modalidad fueron Maryland, Pennsylvania y Delaware. ${ }^{7}$ Por último, en los charter governments, la organización era bastante similar a la de los Gobiernos provinciales. Había tres colonias organizadas de esta manera: Massachusetts, Rhode Island y Connecticut. ${ }^{8}$ Story (1858) aclara que en los Gobiernos de propietarios y en los de la carta real, el derecho a ser gobernado por las leyes de la legislatura local fue reconocido como un principio fundamental. En los Gobiernos provinciales, en cambio, la cuestión estaba en debate. En opinión de los colonos, este era un derecho propio, en cambio, según la Corona, se trataba de un privilegio otorgado discrecionalmente. ${ }^{9}$

Sin perjuicio de la clasificación mencionada, existían diferencias específicas que ponen de manifiesto el mosaico legal del sistema colonial inglés y la ausencia de conexión entre las diferentes colonias, pese a que todas estaban sometidas a la misma autoridad central. ${ }^{10}$ Así, en Maryland, Connecticut y Rhode Island, las leyes locales no requerían la aprobación real; en Rhode Island y Connecticut, el gobernador no tenía poder de veto sobre las leyes locales; en Pennsylvania, el consejo del gobernador no vetaba las leyes locales, pues ejercía una función meramente consultiva del gobernador; y en Massachusetts, el consejo era elegido por la legislatura, pero el gobernador podía vetar a los candidatos. ${ }^{11}$

6 Story (1858, vol. I, § 159, p. 107).

7 Story $(1858, \S 160$, p. 108).

8 Story $(1858, \S 161$, p. 109).

9 Story $(1858, \S 167$, p. 113).

10 Según explica Story (1858): "Though the colonies had a common origin, and owed a common allegiance, and the inhabitants of each were British subjects, they had no direct political connexion with each other. Each was independent of all the others; each, in a limited sense, was sovereign within its own territory. There was neither alliance nor confederacy between them. The assembly of one province could not make laws for another; nor confer privileges, which were to be enjoyed or exercised in another, farther than they could be in any independent foreign state. As colonies, they were also excluded from all connexions with foreign states. They were known only as dependencies; and they followed the fate of the parent country both in peace and war, without having assigned to them, in the intercourse or diplomacy of nations, any distinct or independent existence” (§ 177, p. 122).

11 Story $(1858, \S 171$, pp. 118-119). 
Estas diferencias en la estructura legal de cada colonia y la independencia y separación entre ellas con el tiempo se convirtieron en una gran desventaja, pues les impedían o dificultaban formar lazos comunes o confederarse de manera estable, con miras a presentar un frente común para formular reclamos al Gobierno de Londres. ${ }^{12}$ Todo ello fue gestando gradualmente en las colonias la idea de que debían unirse como medio para proteger sus derechos frente a los abusos de la Corona, de la política mercantilista ${ }^{13} \mathrm{y}$, en particular, de la presión tributaria, que fue finalmente la que desencadenó la Revolución, aunque sus causas no fueron puramente económicas. ${ }^{14}$ Fue así que, desde mediados de la década de 1750 y por espacio de poco más de veinte años, los colonos norteamericanos se reunieron formalmente en cuatro oportunidades: el congreso de

12 Señala Story (1858) que "[t]hey did not possess the power of forming any league or treaty among themselves, which should acquire an obligatory force without the assent of the parent state. And though their mutual wants and necessities often induced them to associate for common purposes of defence, these confederacies were of a casual and temporary nature, and were allowed as an indulgence, rather than as a right. They made several efforts to procure the establishment of some general superintending government over them all; but their own differences of opinion, as well as the jealousy of the crown, made these efforts abortive" (§ 177, p. 122).

13 El mercantilismo fue el arma económica de los Estados nacionales en los siglos XVII y XVIII. Perseguía como objetivo principal la autosuficiencia económica y la prosperidad para el Estado, el cual, a los efectos comerciales, era concebido como un individuo, por lo que resultaba particularmente importante la obtención de un balance favorable de intercambio comercial, ya que si se exportaban más mercaderías de las que eran importadas, más aumentaba el poder económico de la nación. Al igual que Inglaterra, las otras potencias europeas también deseaban un balance favorable en el intercambio con sus colonias, de modo que estas eran empleadas por las metrópolis para producir las materias primas esenciales a bajo costo y proporcionar un mercado ilimitado que absorbiese el sobrante de productos manufacturados, ofreciendo nula competencia económica. Véase Schumpeter (1971, cap. 7).

14 En paralelo con el levantamiento económico en contra de Gran Bretaña, las colonias comenzaron a desarrollar un movimiento de protesta de tono religioso. Hacia 1750, tuvo lugar el llamado Gran Despertar (The Great Awakening), caracterizado por el resurgimiento de las corrientes calvinistas y de su énfasis evangelizador, que tuvo una marcada influencia en el desencadenamiento de la Revolución norteamericana. Tal como explica Paul Johnson (1997, p. 110), en su momento este movimiento no tuvo conciencia de sí mismo ni puede establecerse una fecha para su comienzo o su fin. De hecho, el nombre que recibe le fue dado por Joseph Tracey en un best seller llamado The Great Awakening: a History of the Revival of Religion in the Times of Edwards and Whitefield, publicado en 1842. Sin perjuicio de ello, durante los años previos a la Revolución, estas posturas desembocaron en una encendida defensa de la necesidad de la rebelión y la prédica de los clérigos llegó a ser una punta de lanza del movimiento general de oposición a Gran Bretaña. El reverendo John J. Zubly, en su obra The Law of Liberty, señalaba que si el Evangelio era una ley de libertad, oponerse a este principio era contravenir la voluntad de Dios. Entonces, aquellos que menospreciaban las libertades de los colonos, aquellos que negaban sus derechos -es decir, Inglaterra- atacaban la ley fundamental de Dios. De ese modo, la resistencia a la política inglesa se concebía como la única vía para apartarse de la cólera divina. El parlamento inglés, con su política de opresión económica, había ofendido al Señor y la transgresión de los pactos y cartas originales eran crímenes en contra de Dios. Incluso se llegó a afirmar que el propio rey Jorge III estaba instigado por el demonio. Sobre este tema puede verse Gaustad (1968). 
Albany, el congreso de la Ley de Sellos y los dos Congresos Continentales. De estos, el más importante fue el segundo, pues durante sus sesiones se aprobó la Declaración de la Independencia y fueron sancionados los Artículos de la Confederación, que dieron origen al Congress of the Confederation, el primer órgano legislativo estable que tuvieron los Estados Unidos.

\subsection{El congreso de Albany de 1754}

En 1754, por inspiración de Benjamin Franklin, las colonias decidieron reunirse en una asamblea general para discutir, entre otros asuntos, la defensa de la frontera norte contra los franceses y sus aliados los indígenas. No estaba todavía en la agenda de este congreso la lucha en contra de Inglaterra ni menos aún la independencia, pero no hay dudas de que esta asamblea es uno de los hitos de ese camino.

Se reunió en la ciudad de Albany, en los meses de junio y julio de 1754, donde se congregaron delegados de siete colonias: Connecticut, Maryland, Massachusetts, New Hampshire, New York, Pennsylvania y Rhode Island. De este congreso surgió el llamado Albany Plan of Union, ${ }^{15}$ redactado por Franklin y Thomas Hutchinson, ${ }^{16}$ en el cual sustancialmente se le proponía al Parlamento inglés el dictado de una ley que creara autoridades centrales, dando forma a una suerte de confederación colonial. ${ }^{17}$ La idea era que existiera un presidente general elegido por un Gran Consejo, elegido a su vez por representantes del pueblo de las colonias ${ }^{18}$ y en el cual cada una de ellas tendría un número proporcional de representantes, que se reuniría por primera vez en Philadelphia y se renovaría cada tres años. ${ }^{19}$ El Consejo tenía autoridad legislativa para regular

15 Su texto puede verse en: https://avalon.law.yale.edu/18th_century/albany.asp.

16 Vid. Morison et al. (1980, p. 114).

17 "It is proposed that humble application be made for an act of Parliament of Great Britain, by virtue of which one general government may be formed in America, including all the said colonies, within and under which government each colony may retain its present constitution, except in the particulars wherein a change may be directed by the said act, as hereafter follows".

18 "That the said general government be administered by a President-General, to be appointed and supported by the crown; and a Grand Council, to be chosen by the representatives of the people of the several Colonies met in their respective assemblies".

19 "That within - months after the passing such act, the House of Representatives that happen to be sitting within that time, or that shall especially for that purpose convened, may and shall choose members for the Grand Council, in the following proportion [...] who shall meet for the first time at the city of Philadelphia, being called by the President-General as soon as conveniently may be after his appointment". 
el comercio con los indígenas y establecer nuevos asentamientos. Sus leyes, que no podían contradecir la legislación inglesa, debían ser aprobadas por el rey y su consejo y quedaban tácitamente aprobadas luego de tres años de requerida su aprobación. ${ }^{20}$

\subsection{El congreso de la Ley de Sellos (Stamp Act) de 1765}

Diez años después del congreso de Albany, las colonias se reunieron nuevamente en una asamblea similar convocada en New York, ${ }^{21}$ pero esta vez con motivo de la protesta general levantada contra el impuesto de sellos creado por la Stamp Act de 1765 para sufragar los gastos ocasionados por la llamada French and Indian War. La asamblea tuvo lugar en octubre de 1765 con la participación de 27 delegados de 9 colonias, ${ }^{22}$ bajo la presidencia de Timothy Ruggles de Massachusetts. El congreso aprobó una Declaración de Derechos y Agravios (Declaration of Rights and Grievances), reclamando para sí, en primer lugar, las mismas libertades que las que gozaban los súbditos ingleses que vivían en Inglaterra. ${ }^{23}$ Reafirmaron luego el principio de legalidad en materia tributaria ${ }^{24}$ y la necesidad de regularse a sí mismos en materia impositiva. ${ }^{25}$ Criticaron específicamente el impuesto de sellos creado, ${ }^{26}$ reclamaron la aplicación del juicio

20 "That the laws made by them for the purposes aforesaid shall not be repugnant, but, as near as may be, agreeable to the laws of England, and shall be transmitted to the King in Council for approbation, as soon as may be after their passing; and if not disapproved within three years after presentation, to remain in force".

21 Se reunieron en el llamado Federal Hall, al sur de Manhattan en la zona de Wall Street.

22 No estuvieron presentes Georgia, North Carolina, New Hampshire y Virginia.

23 "That His Majesty's liege subjects in these colonies, are entitled to all the inherent rights and liberties of his natural born subjects within the kingdom of Great-Britain".

24 "That it is inseparably essential to the freedom of a people, and the undoubted right of Englishmen, that no taxes be imposed on them, but with their own consent, given personally, or by their representatives".

25 "That the only representatives of the people of these colonies, are persons chosen therein by themselves, and that no taxes ever have been, or can be constitutionally imposed on them, but by their respective legislatures".

26 "That the late Act of Parliament, entitled, An Act for granting and applying certain Stamp Duties, and other Duties, in the British colonies and plantations in America, etc., by imposing taxes on the inhabitants of these colonies, and the said Act, and several other Acts, by extending the jurisdiction of the courts of Admiralty beyond its ancient limits, have a manifest tendency to subvert the rights and liberties of the colonists". 
por jurados,${ }^{27}$ el ejercicio del derecho de petición ${ }^{28}$ y señalaron que la situación económica creada con la carga impositiva que debían soportar no les permitiría seguir comprando mercaderías en Gran Bretaña. ${ }^{29}$

\subsection{El primer Congreso Continental}

A pesar de estos reclamos, la política británica hacia sus colonias no cambió en absoluto. La Corona y el Parlamento hicieron oídos sordos a estos reclamos y continuaron con la creciente imposición de gravámenes hasta que, en diciembre de 1773, se produjo el famoso Boston Tea Party, que terminó con un cargamento de té arrojado a las aguas del puerto de Boston como repudio contra la llamada Ley del Té (Tea Act 1773) que le otorgaba a la East India Company un monopolio para vender té en las colonias como medio de auxiliar financieramente a la compañía y reducir el contrabando de té holandés. ${ }^{30}$ La respuesta inmediata del Gobierno británico fue la sanción de las llamadas Leyes Intolerables (Intolerable Acts), entre las cuales se dispuso clausurar el puerto hasta que los bostonianos pagaran el té que habían destruido, ${ }^{31}$ se eliminó el derecho de los colonos de Massachusetts a elegir representantes en la asamblea, se le otorgaron amplios poderes al gobernador ${ }^{32}$ y se dispuso que los funcionarios británicos que reprimieran las protestas o se encargaran del cobro de los im-

27 "That trial by jury is the inherent and invaluable right of every British subject in these colonies".

28 "That it is the right of the British subjects in these colonies, to petition the King, Or either House of Parliament. Lastly, That it is the indispensable duty of these colonies, to the best of sovereigns, to the mother country, and to themselves, to endeavour by a loyal and dutiful address to his Majesty, and humble applications to both HoU.S.es of Parliament, to procure the repeal of the Act for granting and applying certain stamp duties, of all clauses of any other Acts of Parliament, whereby the jurisdiction of the Admiralty is extended as aforesaid, and of the other late Acts for the restriction of American commerce".

29 "That the duties imposed by several late Acts of Parliament, from the peculiar circumstances of these colonies, will be extremely burthensome and grievous; and from the scarcity of specie, the payment of them absolutely impracticable. That as the profits of the trade of these colonies ultimately center in Great-Britain, to pay for the manufactures which they are obliged to take from thence, they eventually contribute very largely to all supplies granted there to the Crown".

30 La protesta no estaba directamente relacionada con el monopolio, sino con el impuesto con el cual el té estaba gravado como consecuencia de las Townshend Acts, un conjunto de leyes impositivas impulsadas por Charles Townshend, ministro de economía (Chancellor of the Exchequer) del rey Jorge III. Los colonos sostenían que el pago del impuesto violaba el principio de legalidad tributaria.

31 The Boston Port Act (marzo de 1774).

32 The Massachusetts Government Act (mayo de 1774). 
puestos no serían juzgados por los tribunales de Massachusetts, sino por los de otra colonia o bien por los tribunales ingleses. ${ }^{33}$

Comenzó entonces a organizarse la resistencia a estas leyes y se propuso reunir una convención similar a las dos anteriores. Esta tuvo lugar en el Carpenter's Hall de Philadelphia entre el 5 de septiembre y el 26 de octubre de 1774 y fue luego conocida como el Primer Congreso Continental. Asistieron representantes de todas las colonias, con excepción de Georgia. Lo presidió Peyton Randolph de Virginia y entre sus miembros se encontraban algunos de los que serían luego los padres fundadores de los Estados Unidos, tales como Samuel y John Adams, de Massachusetts, y George Washington y Patrick Henry, de Virginia.

El Congreso aprobó dos documentos importantes. El primero de ellos, suscripto el 14 de octubre, constituye una típica declaración de derechos. ${ }^{34} \mathrm{Co}$ mienza con una exposición de motivos sobre los agravios provocados por las recientes leyes ${ }^{35}$ y luego declara una serie de derechos fundamentales, basados en la teoría política de que los habitantes de las colonias, por las inmutables leyes de la naturaleza (the immutable laws of nature), gozaban de las mismas libertades y garantías que los súbditos ingleses en el Reino Unido, pues sus antepasados,

33 The Administration of Justice Act (mayo de 1774). El artículo 1 de esta ley decía: "[...] it is of the utmost. importance to the general welfare thereof [...] That if any inquisition or indictment shall be found, or if any appeal shall be sued or preferred against any person, for murder, or other capital offence, in the province Of the Massachuset's Bay [...] either in the execution of his duty as a magistrate, for the suppression of riots, or in the support of the laws of revenue, or in acting in his duty as an officer of revenue, or in acting under the direction and order of any magistrate, for the suppression of riots, or for the carrying into effect the laws of revenue, or in aiding and assisting in any of the cases aforesaid [...] it shall and may be lawful for the governor, or lieutenant-governor, to direct, with the advice and consent of the council, that the inquisition, indictment, or appeal, shall be tried in some other of his Majesty's colonies, or in Great Britain [...]".

34 Ver: https://avalon.law.yale.edu/18th_century/resolves.asp.

35 "Whereas, since the close of the last war, the British parliament, claiming a power, of right, to bind the people of America by statutes in all cases whatsoever, hath, in some acts, expressly imposed taxes on them, and in others, under various presences, but in fact for the purpose of raising a revenue, hath imposed rates and duties payable in these colonies, established a board of commissioners, with unconstitutional powers, and extended the jurisdiction of courts of admiralty, not only for collecting the said duties, but for the trial of caU.S.es merely arising within the body of a county: And whereas, in consequence of other statutes, judges, who before held only estates at will in their offices, have been made dependant on the crown alone for their salaries, and standing armies kept in times of peace: And whereas it has lately been resolved in parliament, that by force of a statute, made in the thirty-fifth year of the reign of King Henry the Eighth, colonists may be transported to England, and tried there upon accusations for treasons and misprisions, or concealments of treasons committed in the colonies, and by a late statute, such trials have been directed in cases therein mentioned [...]". 
al salir de Inglaterra hacia América, no se habían despojado de ninguno de los derechos que entonces poseían. ${ }^{36}$ Entre esos derechos figura el de estar representados y participar en una legislatura en cuestiones impositivas y de política interna ${ }^{37}$ el de ser juzgados por sus pares y vecinos ${ }^{38}$ y de ejercer el derecho de reunión y petición. ${ }^{39}$ Sostuvieron también la ilegalidad de que Gran Bretaña tuviera un ejército en las colonias en tiempos de paz sin el consentimiento de aquellas. ${ }^{40}$ Peticionaron finalmente la derogación de una serie de leyes que consideraban violatorias de sus derechos.

El segundo documento, denominado The Articles of Association, ${ }^{41}$ fue suscripto el 20 de octubre. Tenía un contenido económico-comercial, pues pretendía presionar al Parlamento británico para que derogara las llamadas "Leyes Intolerables", estableciendo a tal fin la suspensión de toda exportación, importación y consumo de mercaderías, bienes o productos ingleses. Acusaba directamente al Gobierno británico de las penurias económicas que atravesaban las colonias debido al ruinoso sistema de administración impuesto ${ }^{42}$ y planteaba básicamente la necesidad de llevar adelante una independencia económica completa de Gran Bretaña, prometiendo incluso mejorar la ganadería ${ }^{43}$ y la

36 "That our ancestors, who first settled these colonies, were at the time of their emigration from the mother country, entitled to all the rights, liberties, and immunities of free and natural- born subjects, within the realm of England. That by such emigration they by no means forfeited, surrendered, or lost any of those rights, but that they were, and their descendants now are, entitled to the exercise and enjoyment of all such of them, as their local and other circumstances enable them to exercise and enjoy".

37 "That the foundation of English liberty, and of all free government, is a right in the people to participate in their legislative council: and as the English colonists are not represented, and from their local and other circumstances, cannot properly be represented in the British parliament, they are entitled to a free and exclusive power of legislation in their several provincial legislatures, where their right of representation can alone be preserved, in all cases of taxation and internal polity, subject only to the negative of their sovereign, in such manner as has been heretofore used and accustomed [...]".

38 "That the respective colonies are entitled to the common law of England, and more especially to the great and inestimable privilege of being tried by their peers of the vicinage, according to the course of that law".

39 "That they have a right peaceably to assemble, consider of their grievances, and petition the king; and that all prosecutions, prohibitory proclamations, and commitments for the same, are illegal".

40 "That the keeping a standing army in these colonies, in times of peace, without the consent of the legislature of that colony, in which such army is kept, is against law".

41 Ver: https://www.archivesfoundation.org/documents/1774-articles-association/.

42 "... the present unhappy situation of our affairs is occasioned by a ruinous system of colony administration, adopted by the British ministry about the year 1763, evidently calculated for enslaving these colonies [...]".

43 "We will use our utmost endeavours to improve the breed of sheep, and increase their number to the greatest extent [...]". 
agricultura, así como ciertas industrias -como la de la lana- para lograr un autoabastecimiento. ${ }^{44}$ Se preveía, además, la creación de una comisión que vigilara el cumplimiento de este acuerdo. ${ }^{45}$

\subsection{El Segundo Congreso Continental, los Artículos de la Confederación y el Congreso de la Confederación}

Al finalizar el Primer Congreso Continental, los delegados se comprometieron a reunirse nuevamente en mayo de 1775 . Cumpliendo con este acuerdo, se congregaron el 10 de mayo de ese año en Philadelphia, lo que dio inicio al Segundo Congreso Continental cuando ya habían comenzado las primeras hostilidades con el ejército inglés en las ciudades de Lexington y Concord. Acudieron a esta reunión delegados de las trece colonias y entre ellos se hallaban figuras como Samuel y John Adams, Benjamin Franklin, John Hancock, Patrick Henry, Thomas Jefferson y George Washington.

En la práctica, el Congreso comenzó a actuar inmediatamente como un Gobierno independiente, pese a que no se había producido todavía una declaración formal en tal sentido. Se decidió la formación del Ejército Continental y, en junio, George Washington fue designado comandante en jefe. Fue suscripto también, el 6 de julio, un documento titulado Declaration of Causes of Taking up Arms (Declaración de las Causas para Tomar las Armas), ${ }^{46}$ en el cual Inglaterra fue considerada potencia agresora y se les dio a las colonias el derecho para armarse en contra de los británicos.

Aun así, en el Congreso existían dos posturas. La más radical pretendía declarar inmediatamente la independencia de Gran Bretaña, ${ }^{47}$ mientras que la otra, más conservadora, prefería darle una última chance a la metrópoli inglesa

44 "We will, in our several stations, encourage frugality, economy, and industry, and promote agriculture, arts and the manufactures of this country, especially that of wool [...]".

45 "That a committee be chosen in every county, city, and town, by those who are qualified to vote for representatives in the legislature, whose business it shall be attentively to observe the conduct of all persons touching this association; and when it shall be made to appear, to the satisfaction of a majority of any such committee, that any person within the limits of their appointment has violated this association, that such majority do forthwith cause the truth of the case to be published in the gazette; to the end, that all such foes to the rights of British-America may be publicly known, and universally contemned as the enemies of American liberty [...]".

46 "A Declaration by the Representatives of the United Colonies of North-America, Now Met in Congress at Philadelphia, Setting Forth the Causes and Necessity of Their Taking Up Arms".

Ver: https://avalon.law.yale.edu/18th_century/arms.asp.

47 Representaban esta postura John Adams, de Massachusetts, y Thomas Jefferson, de Virginia. 
intentando llegar a un acuerdo pacífico. ${ }^{48}$ Esta última prevaleció inicialmente y, en julio de 1775, se formuló ante Jorge III la llamada "Petición de la Rama de Olivo" (Olive Branch Petition), redactada por John Dickinson, la cual fue rechazada, ${ }^{49}$ desencadenando con ello los hechos posteriores, entre ellos, la Declaración de la Independencia, aprobada por el Congreso el 4 de julio de 1776, su fecha oficial, aunque el documento fue firmado un mes más tarde. ${ }^{50}$

Este Congreso, en los hechos, se extendió a lo largo de toda la Guerra de la Independencia y concluyó recién en marzo de 1789, para dar paso ya al Congreso de los Estados Unidos una vez que entró en vigencia la Constitución, sancionada en 1787. Antes de ello, fueron sancionados los Artículos de la Confederación y Unión Perpetua (Articles of Confederation and Perpetual Union), el documento constitucional más importante sancionado por el Segundo Congreso Continental, ${ }^{51}$ que rigió desde marzo de 1781 , luego de ser ratificado por los 13 estados, hasta marzo de 1789, cuando entró formalmente en vigencia la Constitución sancionada en septiembre de $1787 . .^{52}$

Los Artículos de la Confederación habían sido aprobados en noviembre de 1777, pero las disputas internas entre los estados -que se repetirían luego en la Convención de Philadelphia- demoraron su ratificación hasta $1781 .{ }^{53} \mathrm{El}$ resultado fue la creación de una Confederación híbrida y débil, denominada

48 Lideraban esta posición John Jay y John Dickinson.

49 Jorge III no solo se negó a recibir la petición, sino que en agosto emitió la Proclamation of Rebellion. Más tarde, en diciembre, el Parlamento sancionó la American Prohibitory Act, que prohibió el comercio inglés con las colonias.

50 He relatado los pormenores del nacimiento y concreción de Declaración de la Independencia en Bianchi (2008, pp. 63-68).

51 En los hechos, fue la primera constitución de los Estados Unidos.

52 La ratificación de la Constitución había tenido lugar en junio de 1788, cuando New Hapmshire otorgó la novena aprobación necesaria para que pudiera entrar en vigencia.

53 Los Artículos fueron preparados por una comisión presidida por John Dickinson, quien en julio de 1776 le presentó un informe al Congreso en el cual proponía establecer un Gobierno central fuerte, donde los estados tuvieran igual representación, dotado de poderes impositivos y que ejerciera control sobre los territorios del oeste. Los delegados al Congreso, no obstante, temían crear un Gobierno federal con amplias facultades, pues veían reflejado en ello el poder ejercido otrora por la Corona británica. El Congreso entonces cambió drásticamente la propuesta de Dickinson y, luego de muchas demoras, el 15 noviembre de 1777 sometió su propuesta a los estados, cuidando de limitar lo menos posible su autonomía. Los estados, por su lado, tenían intereses muy diferentes. Los más pequeños pretendían igual representación que los más grandes, quienes, a su vez, temían tener que sufragar en mayor medida los costos de un Gobierno central. También generaba un conflicto el control sobre los territorios del oeste, ya que los estados linderos con estos pretendían ejercer sobre ellos un control mayor que los restantes. Finalmente, se acordó que el Gobierno central tendría el control de estos territorios, lo que permitió la ratificación final del documento en marzo de 1781. La descripción del conflicto que desató su ratificación puede verse en Story (1858, vol. I, §§ 223-227, pp. 157-160). 
"Los Estados Unidos de América. ${ }^{54}$ Tal como señala Bidegain (1950), "[l]as funciones del poder central eran tan reducidas como podía esperarse en una confederación integrada por Estados que durante el curso de toda su historia, apenas habían mantenido relaciones ente sí, y que, en cambio, habían ejercido el gobierno propio" (p. 27).

El documento constaba de trece cláusulas. ${ }^{55}$ Luego de indicar el nombre de la Confederación, "The United States of America", establecía que cada estado retenía su soberanía y todos los poderes no expresamente delegados, ${ }^{56} \sin$ perjuicio de prometerse mutuamente constituir una unión firme y de ayuda mutua $^{57}$ que conservara la libertad individual de los habitantes de cada estado, quienes podrían circular libremente por el territorio de los demás ejerciendo el comercio. Se aseguraba además que los procedimientos llevados a cabo en un estado tendrían plena validez (full faith and credit) en los restantes. ${ }^{58}$

Estaba previsto un órgano legislativo denominado United States in Congress Assembled, ${ }^{59}$ que, en la práctica, resultó ser una continuación del Segundo Congreso continental, bien que bajo un nombre diferente. Estaba constituido por delegados de todos los estados elegidos según el método que cada uno de ellos hubiera establecido. Debía reunirse anualmente en noviembre y cada estado retenía la facultad de revocar el mandato de sus delegados en cualquier momento y designar otros. Cada estado podía nombrar entre 2 y 7 representantes, que tenían un mandato de hasta 3 años en un período de 6 años. Sin perjuicio de la cantidad de representantes elegidos, cada estado tenía un solo voto al momento de decidir alguna cuestión. Se les garantizaba a los delegados la libertad de expresión en el recinto legislativo y de arresto mientras

54 En la práctica, el Gobierno central creado por los Artículos fue altamente inefectivo, dependía de la discrecionalidad de los estados miembros para su financiamiento económico, no pudo pagar las deudas contraídas durante la Guerra de la Independencia y ni siquiera tuvo fuerza para imponerles a los estados que firmaran el Tratado de París de 1783, por medio del cual se dio por finalizado el conflicto revolucionario con Gran Bretaña. Consecuentemente, fue muy criticado por los líderes federalistas, como Alexander Hamilton y George Washington.

55 Su análisis detallado puede verse en Story (1858, vol. I, §§ 229-241, pp. 161-165).

56 "II. Each state retains its sovereignty, freedom, and independence, and every power, jurisdiction, and right, which is not by this Confederation expressly delegated to the United States, in Congress assembled".

57 "III. The said States hereby severally enter into a firm league of friendship with each other, for their common defense, the security of their liberties, and their mutual and general welfare, binding themselves to assist each other, against all force offered to, or attacks made upon them, or any of them, on account of religion, sovereignty, trade, or any other pretense whatever".

58 Ello constituye un antecedente del artículo IV § 1 de la Constitución de 1787.

59 También se lo ha llamado Congress of the Confederation o Confederation Congress. 
ejercían sus funciones. ${ }^{60} \mathrm{El}$ Congreso ejercía, en forma exclusiva, las relaciones exteriores, celebraba tratados y declaraba la guerra. ${ }^{61}$ Tenía también el poder de resolver conflictos territoriales entre estados. ${ }^{62}$

El órgano ejecutivo era colegiado, temporal y dependía del Congreso. Cuando este entraba en receso, se elegía una comisión integrada por un delegado por cada estado, que actuaría en su reemplazo. ${ }^{63}$ Las decisiones de este cuerpo ejecutivo podían ser adoptadas por nueve de sus miembros. ${ }^{64}$ No estaba prevista la existencia de un poder judicial en la Confederación.

60 "V. For the most convenient management of the general interests of the United States, delegates shall be annually appointed in such manner as the legislatures of each State shall direct, to meet in Congress on the first Monday in November, in every year, with a power reserved to each State to recall its delegates, or any of them, at any time within the year, and to send others in their stead for the remainder of the year.

No State shall be represented in Congress by less than two, nor more than seven members; and no person shall be capable of being a delegate for more than three years in any term of six years; nor shall any person, being a delegate, be capable of holding any office under the United States, for which he, or another for his benefit, receives any salary, fees or emolument of any kind.

Each State shall maintain its own delegates in a meeting of the States, and while they act as members of the committee of the States.

In determining questions in the United States in Congress assembled, each State shall have one vote. Freedom of speech and debate in Congress shall not be impeached or questioned in any court or place out of Congress, and the members of Congress shall be protected in their persons from arrests or imprisonments, during the time of their going to and from, and attendance on Congress, except for treason, felony, or breach of the peace".

61 "VI. No State, without the consent of the United States in Congress assembled, shall send any embassy to, or receive any embassy from, or enter into any conference, agreement, alliance or treaty with any King, Prince or State [...] No two or more States shall enter into any treaty, confederation or alliance whatever between them, without the consent of the United States in Congress assembled [...] No State shall lay any imposts or duties, which may interfere with any stipulations in treaties, entered into by the United States in Congress assembled, with any King, Prince or State, in pursuance of any treaties already proposed by Congress, to the courts of France and Spain [...] No State shall engage in any war without the consent of the United States in Congress assembled, unless such State be actually invaded by enemies [...]".

62 "IX [...] The United States in Congress assembled shall also be the last resort on appeal in all disputes and differences now subsisting or that hereafter may arise between two or more States concerning boundary, jurisdiction or any other caU.S.es whatever; which authority shall always be exercised in the manner following".

63 "IX. [...] The United States in Congress assembled shall have authority to appoint a committee, to sit in the recess of Congress, to be denominated 'A Committee of the States', and to consist of one delegate from each State; and to appoint such other committees and civil officers as may be necessary for managing the general affairs of the United States under their direction - to appoint one of their members to preside, provided that no person be allowed to serve in the office of president more than one year in any term of three years [...]".

64 "X. The Committee of the States, or any nine of them, shall be authorized to execute, in the recess of Congress, such of the powers of Congress as the United States in Congress assembled, by the consent of the nine States [...]". 


\section{El debate en la Convención de Philadelphia 3.1. Convocatoria y tareas preparatorias}

Bajo este esquema, el Gobierno de la Confederación fue un fracaso. En palabras de Washington, citadas por Story (1858), la Confederación no era más que una "sombra sin sustancia y el Congreso un cuerpo ineficaz" (nugatory). ${ }^{65}$ Fue por ello que el 21 de febrero de 1787, el Congreso Continental dispuso que en mayo se reuniera una convención en Philadelphia. ${ }^{66} \mathrm{Su}$ objeto era revisar los Artículos de la Confederación, pero el resultado fue la sanción de una Constitución enteramente diferente, mucho más vigorosa, que está vigente todavía y ha sido el modelo de muchas otras.

Sin perjuicio del valioso trabajo institucional llevado a cabo por la Convención de Philadelphia, algunos autores han puesto de manifiesto los intereses económicos que impulsaron a los constituyentes. En 1913, Charles A. Beard publicó una interesante y polémica obra, destinada a demostrar el trasfondo de los intereses económicos que animaban a los convencionales. Sus conclusiones generaron una fuerte reacción en sus contemporáneos y en autores posteriores, ya que bajo su interpretación la Constitución no parecía ser más que el resultado de una transacción sobre intereses patrimoniales entre comerciantes, propietarios, poderosos terratenientes y tenedores de bonos públicos, lo que obviamente restaba buena parte de patriotismo e interés institucional a la gesta constituyente. ${ }^{67}$

La reunión estaba programada para el 14, pero recién obtuvo quorum para sesionar el 25. La Convención trabajó formalmente desde esa fecha por espacio de cuatro meses, hasta el 17 de septiembre, fecha en que la Constitución fue

65 "[t]he confederation appears to me to be little more, than a shadow without the substance; and congress a nugatory body, their ordinances being little attended to” (Story, 1858, vole I, § 247, p. 169).

66 El año anterior, en septiembre, ya había intentado reunirse una Convención en la ciudad de Annapolis, pero la convocatoria fracasó ya que solo acudieron representantes de cinco estados.

67 Según Beard (1956), “... es enteramente falso el concepto de que la Constitución es una pieza de legislación abstracta, que no refleja grupos de interés y no reconoce antagonismos económicos. Fue un documento económico escrito con extraordinaria destreza por hombres cuyos intereses como propietarios estaban en juego de modo tal que apelaron directamente y sin equivocaciones a idénticos intereses para todo el país" (p. 188). En el Capítulo V, uno de los centrales en el libro, Beard (1956) pasa revista a la condición económica de cada uno de los constituyentes con el objeto de determinar cuáles eran los intereses que cada uno estaba dispuesto a defender. Concluye señalando que la mayoría de ellos eran abogados y provenían de ciudades situadas en o cerca de la costa, es decir, en aquellas zonas donde más personalidades se hallaban congregadas. Nadie representaba directamente a las clases de pequeños agricultores. La abrumadora mayoría -por lo menos cinco sextos- estaban personal y directamente interesados en el resultado de su labor en Philadelphia y se beneficiaron, en mayor o menor medida, con la Constitución. 
aprobada. ${ }^{68}$ De los trece estados, concurrieron a la Convención todos menos Rhode Island, que no mandó delegados. ${ }^{69}$ No hubo una representación igualitaria, ya que algunos estados tuvieron más delegados que otros. ${ }^{70}$ En total fueron designados 74 , de los cuales asistieron $55 ;^{71}$ el promedio de asistencia a las sesiones fue de $33^{72}$ y estuvieron ausentes por diferentes motivos figuras destacadas. ${ }^{73}$

Reunida la Convención, se desarrollaron los trabajos preliminares propios de todo cuerpo legislativo recién constituido. George Washington fue elegido presidente por unanimidad y William Jackson fue designado secretario; se examinaron las credenciales de cada diputado y se designó una comisión para

68 Se inició luego el proceso de ratificación, que concluyó el 21 de junio de 1788 con la aprobación dada por New Hampshire. En marzo del año siguiente, como dije antes, entró en vigencia la Constitución.

69 New Hampshire se unió casi al final, y cuando la Constitución fue firmada, de los tres delegados enviados por New York solo quedaba Alexander Hamilton.

70 La delegación de Virginia estaba liderada por su ciudadano más destacado, George Washington, que fue elegido presidente de la Convención, secundado por Edmund Randolph y James Madison. También fueron delegados de Virginia John Blair, George Wythe y George Mason, redactor este último del Bill of Rights de su estado. New Jersey estuvo representada, entre otros, por David Brearly, William Paterson, Jonathan Dayton y William Livingston. Benjamin Franklin fue el más popular de la nutrida delegación de Pennsylvania. Además de Franklin, actuaron Thomas Mifflin, Robert Morris, Jared Ingersoll, James Wilson, George Clymer y Thomas Fitzsimons. North Carolina envió a Alexander Martin, William R. Davie y Richard Spaigth; South Carolina, a Charles Pinckney y Pierce Butler; Delaware, a George Read y John Dickinson; New York envió a Alexander Hamilton, Robert Yates y John Lansing; Georgia fue representada, entre otros, por William Pierce y Abraham Baldwin; Roger Sherman y Oliver Ellsworth representaron a Connecticut y Elbribge Gerry y Nathaniel Gorham a Massachusetts. También fueron delegados de este estado Nathaniel Gordman y Rufus King. Sus edades oscilaban en un rango que va desde la ancianidad de Franklin, que contaba con 81 años, a la juventud de Dayton, de apenas 27, bien que otros muchos estaban cerca de los 30 años. Madison tenía 36; Baldwin, 33; Hamilton, 30 y Davie, Pinckney y Spaight no llegaban a 30. En total concurrieron 55 convencionales -sobre un total de 72 que fueron nominados-, de los cuales 39 firmaron la Constitución.

71 Todos ellos eran figuras prominentes de su época: 8 habían firmado la Declaración de la Independencia, 7 habían sido gobernadores de sus estados y 39 habían sido miembros del Congreso de la Confederación.

72 Los convencionales más influyentes fueron: Gouverner Morris y James Wilson, de Pennsylvania; James Madison, de Virginia, y Roger Sherman, de Connecticut, con más de 100 intervenciones cada uno. También se destacaron George Mason y Edmund Randolph de Virginia, Oliver Ellsworth de Connecticut, Rufus King y Elbridge Gerry de Massachusetts, John Rutledge y Charles Pickney de South Carolina, Alexander Hamilton de New York, John Dickinson de Delaware y William Paterson de New Jersey.

73 No asistieron John Jay, que era secretario de asuntos exteriores, Thomas Jefferson, embajador en Francia, y John Adams, embajador en Inglaterra. También estuvieron ausentes personalidades destacadas de la Independencia, como Samuel Adams, Patrick Henry, John Hancock, Christopher Gadsen y Richard Henry Lee. 
redactar el reglamento y otras disposiciones. Asimismo, luego de cierto debate, se decidió que cada estado tendría un voto, ${ }^{74}$ que 7 estados formarían quorum, que las decisiones se tomarían por mayoría ${ }^{75}$ y que los debates serían secretos.

Tan escrupulosa fue esta regla que los debates de la Convención no se conocieron sino luego de varios años, cuando el Congreso ordenó imprimirlos luego de la Guerra de 1812 contra Inglaterra. El resultado parece haber sido desalentador, pues el trabajo del secretario no reflejaba adecuadamente los debates. Este déficit fue luego suplido por las notas que tomaron algunos miembros de la Convención, que ayudaron a esclarecer puntos que no suplía el texto oficial. De todos ellos, la contribución más importante fue la de James Madison. Elegido como delegado por Virginia, fue uno de los primeros en instalarse en Philadelphia. Había llegado allí munido de dos estudios que había preparado, titulados "Study of Ancient and Modern Confederacies" y "Vices of the Political System of the United States", lo que le permitió presentar inmediatamente ante la asamblea constituyente su plan de gobierno, consistente en la creación de poderes nacionales fuertes como modo de obtener uniformidad en la regulación de ciertas materias. Este plan (Virginia Plan) fue presentado luego ante la Convención por el gobernador y convencional Edmund Randolph. Además de su contribución en la preparación de este plan y de su labor como principal redactor de la Constitución, aporte incrementado luego con sus artículos en El Federalista, Madison tuvo el cuidado de escribir notas detalladas sobre los procedimientos llevados a cabo por la Convención, que se convirtieron en un documento indispensable para conocer la labor de la asamblea constituyente. Este trabajo se publicó inicialmente en 1840, luego de la muerte de Madison, bajo el título Journal of the Federal Convention, que ha tenido numerosas ediciones. ${ }^{76}$

74 Se siguió en esto la regla aplicada en los Artículos de la Confederación.

75 No obstante, esta regla fue modificada luego, permitiéndose reconsiderar los votos emitidos, algo que sucedió con frecuencia a lo largo de la convención.

76 Más tarde, en 1911, Max Farrand publicó una obra en tres volúmenes llamada The Records of the Federal Convention of 1787, que se convirtió desde entonces en la fuente principal para el análisis de los debates de la Convención. Farrand recopiló ordenadamente los debates tomando como base, por un lado, el registro llevado por William Johnson, secretario de la Convención, enviados al Departamento de Estado por Washington en 1796 e impresos en 1819 por disposición del Congreso, bajo la supervisión de John Quincy Adams, entonces secretario de Estado, y, por el otro, el trabajo de James Madison. La obra fue publicada originalmente por Yale University Press y actualmente se la puede consultar online en: https://oll.libertyfund.org/title/farrand-the-records-of-the-federal-convention-of-1787-3vols. También puede verse Farrand (1913). 


\subsection{La cuestión central}

Tal como veremos en los párrafos siguientes, la cuestión central de los debates estuvo enfocada en el diseño del Congreso, en particular, el problema más arduo fue la proporcionalidad de la representación en las cámaras legislativas, una cuestión que ya se había presentado al redactar los Artículos de la Confederación y que rebrotó vivamente en la Convención de Philadelphia, al punto que estuvo al borde de hacerla fracasar. Esta disputa enfrentaba a los estados grandes y económicamente poderosos -tales como Virginia, Pennsylvania y Massachusetts- con los estados pequeños. Los primeros pretendían que ambas cámaras legislativas se integraran mediante una regla de estricta proporcionalidad poblacional. A los segundos esto los perjudicaba, pues disminuía enormemente la cantidad de sus representantes y temían, con fundada razón, que el Congreso fuera dominado por los estados grandes. La cuestión fue zanjada en el "Gran Compromiso" del 16 de julio, en el cual se acordó que la Cámara de Representantes se integraría sobre la base proporcional de la población y que en el Senado cada estado tendría igualdad de votos.

\subsection{El Plan de Virginia}

El 29 de mayo, una vez finalizadas las tareas de organización, comenzaron los debates. Hasta ese momento, la convocatoria tenía el modesto propósito de revisar los Artículos de la Confederación, sin embargo, la convención tomó un giro de más alto vuelo cuando Edmund Randolph, gobernador y representante de Virginia, abrió el fuego presentando un plan integral de reformas, elaborado por James Madison, que preveía la creación de un Gobierno nacional mucho más fuerte y enteramente diferente al de la Confederación. ${ }^{77}$ Conocido como el "Plan de Virginia", fue finalmente la base de la Constitución, bien que con algunas modificaciones importantes.

Desarrollado en quince propuestas, ${ }^{78}$ el Plan de Virginia preveía un Gobierno separado en tres ramas: legislativa, ejecutiva y judicial. La legislatura estaría dividida en dos cámaras, una elegida por el pueblo de los estados y la otra por los miembros de la primera. ${ }^{79}$ El ejecutivo sería elegido por la legislatura nacio-

77 Ese mismo día, Charles Pinckney, de South Carolina, presentó también una propuesta, pero no fue considerada.

78 Ver las partes relevantes de su texto en el Anexo II (p. 434).

79 Nunca fue objetado en el curso de la Convención que el Congreso fuera bicameral, pues ello venía de la tradición inglesa y colonial, aunque no estaba reflejado en los Artículos de la Confederación. 
nal, sin posibilidad de acceder a un segundo período. Los jueces, divididos en dos instancias (una Corte Suprema y cortes inferiores), también serían elegidos por la legislatura. El plan preveía también que el ejecutivo y un "conveniente número de la judicatura nacional" conformarían un consejo con facultades para vetar las leyes, decisión que podía quedar sin efecto mediante la insistencia de las dos cámaras legislativas. Se establecía asimismo la posibilidad de incorporar nuevos estados y de reformar la Constitución, para lo cual, una vez aprobada la enmienda por el Congreso, este debía someterla a la aprobación de convenciones especialmente convocadas al efecto por los estados.

A partir de allí, y por espacio de dos semanas, la Convención se constituyó en comisión para analizar el Plan de Virginia, el cual enfrentó la oposición de algunos estados, como Maryland, New Jersey y Delaware. No era para menos. El Plan de Virginia, más que reformar los Artículos de la Confederación, los alteraba completamente en dos aspectos fundamentales.

En primer lugar, proponía la creación de un Gobierno federal fuerte por encima de los estados. Se establecía de este modo una doble soberanía: la del Gobierno federal y la de los Gobiernos estaduales, algo que hasta 1787 jamás había sido pensado. Aunque en la sesión del 30 de mayo Randolph se esforzó en explicar que los poderes otorgados al Gobierno federal, tomados de los estados, solo tenían el propósito de dotarlo de la capacidad de defenderse a sí mismo, ${ }^{80}$ era evidente que los estados debían resignar una amplia porción de las facultades ejercidas hasta ese momento.

En segundo lugar, se pretendía imponer la representación proporcional en ambas cámaras legislativas. ${ }^{81}$ Esto permitía el dominio de los estados grandes sobre los más pequeños, pues le otorgaba a Virginia, Pennsylvania y Massachusetts la posibilidad de elegir 13 miembros sobre un total de 28 en el Senado y una porción similar en la Cámara de Representantes. Luther Martin, de

Parecería ser que uno de los que objetó la composición bicameral fue Jefferson, luego de sancionada la Constitución. Una anécdota - no comprobada- cuenta que al regresar de Francia, donde había sido embajador mientras se sancionaba la Constitución, Jefferson desayunaba con Washington y se quejaba de que la existencia de dos cámaras dilataría el proceso legislativo. Mientras hablaba, volcó el café en un plato y Washington le preguntó por qué lo hacía. Jefferson le respondió que era para enfriar el café. Washington le dijo entonces que era conveniente volcar las leyes en el plato del Senado para enfriarlas (Vid. Farrand, 1913, p. 74).

80 "It is only meant to give the national government a power to defend and protect itself. To take therefore from the respective legislatures or States, no more sovereignty than is competent to this end" (Farrand, 1911a, p. 42).

81 En la Cámara de Representantes era directa y en el Senado era indirecta, pues sus miembros eran elegidos por los integrantes de la primera. 
Maryland, en la sesión del 20 de junio dijo que el Plan sometía a los estados chicos a la esclavitud de los grandes; ${ }^{82}$ Dickinson, de Delaware, en la sesión del 15 de junio reconoció que prefería someterse a un poder extranjero que ser privado del voto igualitario para todos los estados en ambas cámaras; ${ }^{83}$ y Paterson, de New Jersey, en la sesión del 9 de junio había dicho que su estado jamás aprobaría la propuesta, pues sería "tragado" por los estados grandes y que prefería someterse a un monarca o a un déspota antes que tener tal destino. ${ }^{84}$

\subsection{El Plan de New Jersey}

En la sesión del 11 de junio fueron votadas las propuestas del Plan de Virginia. La referida al modo de elección de los senadores fue aprobada por 6 votos contra 5. Si bien el resultado era ajustado, era indudable que los estados grandes estaban ganando la partida. A fin de contrarrestar esta tendencia que ya se insinuaba como definitiva, en la sesión del 15 de junio William Paterson, de New Jersey, presentó un plan alternativo, el Plan de New Jersey, que fue apoyado por Connecticut, New York y Delaware. Consistía en nueve resoluciones que se limitaban a reformar los Artículos de la Confederación otorgándole poderes impositivos al Congreso, creando un ejecutivo pluripersonal y un tribunal superior elegido por el ejecutivo con jurisdicción originaria en casos de juicio político y jurisdicción apelada respecto a los tribunales estaduales. Preveía también una cláusula de supremacía de la Constitución. ${ }^{85}$ Sin decirlo expresamente, el Plan de New Jersey mantenía la regla de un voto por cada estado establecida en los Artículos de la Confederación.

\subsection{El debate sobre los planes presentados}

Luego de sometido el Plan de New Jersey, la Convención nuevamente se cons-

82 "[T]he propositions on the table were a system of slavery for 10 States: that as Va. Masts. \& Pa. have 42/90 of the votes they can do as they please without a miraculous Union of the other ten: that they will have nothing to do, but to gain over one of the ten to make them complete masters of the rest, that they can then appoint an Execute: \& Judiciary \& legislate for them as they please" (Farrand, 1911a, p. 347).

83 "We would sooner submit to a foreign power, than submit to be deprived of an equality of suffrage, in both branches of the legislature, and thereby be thrown under the domination of the large States" (Farrand, 1911a, p. 242).

84 "New Jersey will never confederate on the plan before the Committee. She would be swallowed up. He had rather submit to a monarch, to a despot, than to such a fate" (Farrand, 1911a, p. 179).

85 Ver las partes relevantes de su texto en el Anexo III (p. 436). 
tituyó en comisión para analizarlo. Seis delegados llevaron en esa oportunidad la voz cantante: a favor del nuevo plan se pronunciaron Paterson, Ellsworth, de Connecticut, y Lansing, de New York; en contra se alinearon Madison, Wilson y Randolph. En el curso de este debate, hizo sentir su voz, por primera y prácticamente única vez en el curso de la Convención, Alexander Hamilton. Se había mantenido apartado de Lansing y Yates, los otros delegados de New York, y, con poco tacto político, aprovechó esta ocasión para exponer un plan de gobierno, muy elaborado, pero completamente diferente a los ya presentados, ${ }^{86}$ que luego sus detractores calificaron de monárquico, aun cuando no lo era en realidad. Propuso, en síntesis, un sistema fuertemente centralizado, ${ }^{87}$ que, al no tener en cuenta para nada el espíritu localista de la mayoría de los estados, estaba destinado al más rotundo rechazo, como efectivamente ocurrió. ${ }^{88}$

En la sesión del martes 19 de junio, luego de una extensa exposición de Madison -el último de los oradores-, en la que reconoció que el nudo del problema era la representación y que todas las otra cuestiones eran superables, ${ }^{89} \mathrm{se}$ sometió a votación si debía optarse por el Plan de Virginia o el de New Jersey. ${ }^{90}$ La elección se inclinó por el primero de ellos por 7 votos contra 3. El Plan de New Jersey solo obtuvo el voto de su estado y los de New York y Delaware. El voto de Maryland resultó dividido.

\subsection{El Gran Compromiso}

Con la opción a favor del Plan de Virginia, habían triunfado los estados grandes, pero faltaba todavía un largo camino para llegar a un acuerdo sobre el texto

86 El plan de Hamilton puede verse en Farrand (1911c, pp. 617 y ss.).

87 Hamilton propuso que el ejecutivo y los senadores fueran elegidos por electores por tiempo indeterminado mientras durara su buena conducta; que el ejecutivo tuviera amplios poderes, entre ellos, un veto absoluto; que los gobernadores estaduales fueran elegidos por el Gobierno central y pudieran vetar la legislación local.

88 William Johnson, de Connecticut, en la sesión del 21 de junio expresó: "El caballero de New York, con audacia y decisión, ha propuesto un plan totalmente diferente a los otros y a pesar de haber sido elogiado por todos, nadie lo ha apoyado" ("A gentleman from New-York, with boldness and decision, proposed a system totally different from both; and though he has been praised by everybody, he has been supported by none") (Farrand, 1911a, p. 363).

89 "The great difficulty lies in the affair of Representation; and if this could be adjusted, all others would be surmountable" (Farrand, 1911a, pp. 321).

90 " $[. .$.$] whether the Committee should rise and Mr. Randolph's propositions be re-reported without$ alteration, which was in fact a question whether Mr. Randolph's should be adhered to as preferable to those of Mr. Patterson" (Farrand, 1911a, p. 322). 
de cada cláusula y el punto clave para ello era la composición y elección de los miembros de cada cámara legislativa. Fue en este momento que la Convención alcanzó el clima de mayor tensión. A comienzos de julio, poco se había avanzado en la materia y, en algunos casos, los delegados de un mismo estado no se ponían de acuerdo, neutralizando el voto de ese estado. En medio de esta situación, el lunes 2 de julio se sometió a votación si en el Senado la representación sería igualitaria; la votación resultó empatada: 5 estados votaron por la afirmativa y 5 por la negativa, con un voto dividido.

Era indudable que, a esa altura, la Convención, estaba a punto de estancarse. Charles Pickney propuso entonces la formación de una comisión integrada por un representante de cada estado a fin de intentar un acuerdo. Pese a la oposición de los estados grandes, esta propuesta fue aprobada y resultaron electos Gerry, Elseworth, Yates, Paterson, Franklin, Bedford, Martin, Mason, Davy, Rutlidge y Baldwin. El 5 de julio, la Comisión presentó en la Convención una propuesta que contenía dos puntos, sujetos a la condición de que ambos fueran aprobados: 1) en la Cámara de Representantes la representación sería proporcional a la población tomando una base de 40000 habitantes; los estados que no tuvieran esa población tendrían un representante; las leyes de contenido económico debían originarse en la Cámara de Representantes sin posibilidad de ser enmendadas por el Senado; y 2) en el Senado, cada estado tendría igual cantidad de votos. ${ }^{91}$

Luego de arduas discusiones y reproches, el 16 de julio se acordaron finalmente, por muy escasa mayoría, ${ }^{92}$ las bases estructurales del Congreso de los Estados Unidos. Fue resuelto allí que en la Cámara de Representantes la representación sería proporcional a la población y en el Senado cada estado tendría igual cantidad de votos. Se estableció, asimismo, la composición de la primera legislatura,

91 "That the subsequent propositions be recommended to the Convention, on condition that both shall be generally adopted. 1st That in the first branch of the Legislature each of the States now in the Union be allowed one Member for every forty thousand inhabitants of the description reported in the seventh resolution of the Committee of the whole House. That each State not containing that number shall be allowed one Member - That all Bills for raising or appropriating money and for fixing the salaries of the Officers of the Government of the United States, shall originate in the first Branch of the Legislature, and shall not be altered or amended by the second Branch - and that no money shall be drawn from the public Treasury but in pursuance of appropriations to be originated by the first Branch. 2ndly That in the second Branch of the Legislature each State shall have an equal Vote" (Farrand, 1911a, p. 524).

92 En una decisión 5-4, votaron a favor: Connecticut, New Jersey, Delaware, Maryland y North Carolina y, en contra, Pennsylvania, Virginia, South Carolina y Georgia. El voto de Massachusetts quedó dividido y dos de los representantes de New York para ese entonces ya se habían retirado de la Convención. Quedaba solamente Hamilton. 
fijándose el número de representantes de cada estado; la obligación de hacer un censo poblacional cada diez años y de redistribuir los distritos electorales para reflejar los cambios poblacionales y territoriales -por adición o divisiónque pudiera experimentar cada estado. Se dispuso también que las leyes impositivas y las de aprobación de gastos públicos debían originarse en la Cámara de Representantes, sin que el Senado pudiera modificarlas. ${ }^{93}$

\subsection{La tarea posterior}

Desde el Gran Compromiso del 16 de julio hasta la aprobación definitiva de la Constitución, la Convención trabajó febrilmente en la redacción del texto. Fue designada una comisión redactora (Committee of Detail) integrada por cinco miembros -tres de los cuales representaban a los estados grandes-, ${ }^{94}$ que el 6 de agosto presentó un proyecto de Constitución en 23 artículos, 6 de los cuales (los artículos IV a IX) estaban dedicados al Congreso, tan solo uno al Poder Ejecutivo (artículo X) y otro al Poder Judicial (artículo XI). ${ }^{95}$ Durante el curso de los debates posteriores, este proyecto fue intensamente modificado hasta convertirse en la Constitución sancionada el lunes 17 de septiembre.

Dado que este no es un estudio específico sobre la Convención de Philadelphia, no me detendré con detalle en los debates específicos de cada cláusula. Me limitaré tan solo a mencionar algunos aspectos tratados por aquella relativos al Congreso que me parecen importantes. El análisis más detallado de las secciones y cláusulas del artículo I será materia de las siguientes partes de este trabajo.

Un dato a tener en cuenta es que hasta que fue elaborado el proyecto de constitución por el Committee of Detail, la Convención no había empleado la palabra "Congreso", que figuraba en los Artículos de la Confederación. Se refería, en cambio, a la "legislatura de los Estados Unidos" y las cámaras eran designadas como "primera rama" (first branch), en alusión a la Cámara de Representantes, y "segunda rama" (second branch), en alusión al Senado. Recién en el proyecto del Committee of Detail se emplearon las denominaciones Congress (artículo III), House of Representatives (artículo IV) y Senate (artículo V).

En cuanto a la cantidad de representantes y de senadores, el 8 de agosto se

93 Ver Anexo IV (p. 438).

94 Sus integrantes fueron: Rutledge (South Carolina), Randolph (Virginia), Gorham (Massachusetts), Ellsworth (Connecticut) y Wilson (Pennsylvania). Casi todos ocuparon luego cargos de importancia. Randolph fue el primer attorney general y Rutledge, Ellsworth y Wilson fueron jueces de la Corte Suprema.

95 El proyecto está transcripto en Farrand (1911b, pp. 177-189). 
decidió que los primeros serían 1 por cada 40000 habitantes, cantidad que se redujo a 30000 el último día de la convención, es decir, el 17 de septiembre. Así, hasta el primer censo, la cantidad de legisladores en el House fue de 65. A su vez, el 14 de julio, a propuesta de Elbridge Gerry, se decidió que cada senador votaría en forma individual y el 23 de julio se acordó que habría 2 senadores por cada estado.

Antes de ello, el 21 de junio, se había decidido que el término del mandato de los representantes sería de dos años y el 26 de junio se resolvió que el de los senadores sería de 6 años y se renovarían por tercios. Ese mismo día se votó también, por unanimidad, que los proyectos de ley podían originarse en cualquiera de las dos cámaras. El 14 de agosto se aprobó que los salarios de senadores y representantes serían pagados por el Tesoro Nacional. ${ }^{96}$

Estas y otras muchas decisiones fueron conformando lo que resultó ser el artículo I de la Constitución. Ciertamente, este artículo, al igual que todos los restantes, no fueron más que una obra imperfecta e incompleta, ${ }^{97}$ producida por un grupo de hombres a los que les costó mucho llegar a un acuerdo y por momentos estuvieron al borde de fracasar. ${ }^{98} \mathrm{Al}$ concluir la Convención, algunos manifestaron su disenso con ella y hubo quienes se negaron a firmarla, como Randolph, Mason y Gerry. De las palabras de todos ellos, las de Franklin, con la sabiduría que le daban los años vividos, fueron tal vez las más sensatas. Confesó no estar de acuerdo con muchos aspectos de la Constitución, pero reconoció que nadie podía esperar la perfección de una asamblea de personas en la que todos volcaban su sabiduría, sus errores, sus intereses personales y sus pasiones. Con todas sus limitaciones - dijo-, la Constitución era lo más parecido a la perfección que se podía lograr y con ese sentimiento la aprobaba, estando seguro de que no era la mejor. ${ }^{99}$ Tal vez, el reconocimiento de sus mu-

96 Antes de ello, Ellsworth había propuesto que los salarios fueran pagados por los estados, pero Randolph y Hamilton se opusieron, señalando que ello los haría dependientes de los estados, viciando su imparcialidad.

97 Faltaba una declaración de derechos, el Bill of Rights, que fue aprobado años más tarde en las Enmiendas I a X.

98 Mientras se firmaba la Constitución, Franklin comentó que, durante los debates, muchas veces miraba el sillón de la presidencia en cuyo respaldo está tallado un sol naciente, preguntándose si realmente representaba el amanecer o el crepúsculo.

99 "In these sentiments, Sir, I agree to this Constitution with all its faults, if they are such [...] when you assemble a number of men to have the advantage of their joint wisdom, you inevitably assemble with those men, all their prejudices, their passions, their errors of opinion, their local interests, and their selfish views. From such an Assembly can a perfect production be expected? It therefore astonishes me, Sir, to find this system approaching so near to perfection as it does [...] Thus I consent, Sir, to this Constitution because I expect no better, and because I am not sure, that it is not the best" (Farrand, 1611b, p. 642-643). 
chos defectos y debilidades sea una de las claves de la estabilidad del sistema político norteamericano.

\section{Los artículos de Madison en El Federalista}

Puestos a escribir en defensa de la Constitución contra los ataques de los antifederalistas, ${ }^{100}$ que arreciaban mientras se llevaba a cabo el proceso de ratificación por parte de los estados, ${ }^{101}$ le tocó a James Madison la tarea de explicar la organización y funciones del Congreso. Lo hizo en 15 artículos, publicados en The Independent Journal de New York, junto con los de Alexander Hamilton y John Jay, ${ }^{102}$ recopilados luego en El Federalista ${ }^{103}$ como capítulos 52 a 66, dedicados los 10 primeros a la Cámara de Representantes; y los 5 restantes, al Senado. ${ }^{104}$

En relación con la Cámara de Representantes, lo primero que analiza son las elecciones de los legisladores, señalando que el sufragio es esencial para el Gobierno republicano ${ }^{105}$ y preguntándose cada cuanto deberían tener lugar tales elecciones. ${ }^{106} \mathrm{Su}$ conclusión es que la elección debe tener lugar cada dos años, pues ello asegura, por un lado, que los legisladores tengan más tiempo para recabar información y conocimientos sobre la legislación que propongan y, por el otro, que en caso de producirse una elección irregular, la investigación

100 Entre los opositores se hallaban George Mason, de Virginia, Elbridge Gerry, James Winthrop y John Hancock, de Massachusetts, George Clinton, de New York, Patrick Henry y Richard H. Lee, de Virginia, convencidos de que el Gobierno federal creado por la Constitución ahogaría la libertad de los estados. Se temía que la presidencia fuera un paso hacia la monarquía, particularmente porque la Constitución permitía la reelección sin límites y que el Congreso, investido de una amplia autoridad, se convirtiera en el instrumento de un poder arbitrario. En el bando opuesto, los defensores más ardientes de la Constitución, además de Washington, Madison, Hamilton y Jay, fueron entre otros: Benjamin Franklin y Rufus King.

101 En el Anexo V (p. 438) menciono cómo se desarrolló el proceso de ratificación.

102 Todos ellos escribieron bajo el seudónimo de Publius.

103 Un estudio de los diferentes tópicos que abarca esta obra puede verse en Carey (1989).

104 A los fines de este análisis, he consultado la Gideon Edition de 1818, editada luego por George Carey y James McLean (2001). Una excelente versión en español es la de Fondo de Cultura Económica, que tiene numerosas ediciones con prólogo y revisión de Gustavo R. Velasco.

105 "The definition of the right of suffrage is very justly regarded as a fundamental article of republican government. It was incumbent on the convention, therefore, to define and establish this right in the constitution" (El Federalista, $\mathrm{N}^{\circ}$ 52).

106 "Frequent elections are unquestionably the only policy, by which this dependence and sympathy can be effectually secured. But what particular degree of frequency may be absolutely necessary for the purpose, does not appear to be susceptible of any precise calculation, and must depend on a variety of circumstances with which it may be connected" (El Federalista, №52). 
del hecho no consuma todo el período legislativo. ${ }^{107}$ Analiza luego qué parámetros deben tenerse en cuenta para calcular la cantidad de representantes por cada estado y se pregunta si debe tomarse como base la población, la riqueza o una combinación de ambas y sostiene que esta última es la fórmula más conveniente. ${ }^{108}$ Considera seguidamente cuántos miembros debe tener en total la Cámara de Representantes. Partiendo de que la Convención había establecido provisionalmente una cámara de 65 miembros hasta que se llevara a cabo el primer censo, Madison hace algunos cálculos -muy estimativos- sobre el crecimiento poblacional y concluye que, en medio siglo más, los legisladores llegarían a ser 400 , un número que le resulta satisfactorio. ${ }^{109}$ Sin dudas, su cálculo

107 "The second question stated is, whether biennial elections be necessary or useful? The propriety of answering this question in the affirmative, will appear from several very obvious considerations. No man can be a competent legislator, who does not add to an upright intention and a sound judgment, a certain degree of knowledge of the subjects on which he is to legislate. A part of this knowledge may be acquired by means of information, which lie within the compass of men in private, as well as public stations. Another part can only be attained, or at least thoroughly attained, by actual experience in the station which requires the use of it. The period of service ought, therefore, in all such cases, to bear some proportion to the extent of practical knowledge, requisite to the due performance of the service. The period of legislative service established in most of the states for the more numerous branch is, as we have seen, one year. The question then may be put into this simple form: does the period of two years bear no greater proportion to the knowledge requisite for federal legislation, than one year does to the knowledge requisite for state legislation? The very statement of the question, in this form, suggests the answer that ought to be given to it [...]It is an inconvenience mingled with the advantages of our frequent elections, even in single states, where they are large, and hold but one legislative session in the year, that spurious elections cannot be investigated and annulled in time for the decision to have its due effect [...] Each house is, as it necessarily must be, the judge of the elections, qualifications and returns of its members; and whatever improvements may be suggested by experience, for simplifying and accelerating the process in disputed cases, so great a portion of a year would unavoidably elapse before an illegitimate member could be dispossessed of his seat, that the prospect of such an event would be little check to unfair and illicit means of obtaining a seat" (El Federalista, $\mathrm{N}^{\circ} 53$ ).

108 "[...] the establishment of a common measure for representation and taxation, will have a very salutary effect. As the accuracy of the census to be obtained by the congress, will necessarily depend, in a considerable degree, on the disposition, if not the co-operation of the states, it is of great importance that the states should feel as little bias as possible, to swell or to reduce the amount of their numbers. Were their share of representation alone to be governed by this rule, they would have an interest in exaggerating their inhabitants. Were the rule to decide their share of taxation alone, a contrary temptation would prevail. By extending the rule to both objects, the states will have opposite interests, which will control and balance each other, and produce the requisite impartiality" (El Federalista, $\mathrm{N}^{\circ}$ 54).

109 "The number of which this branch of the legislature is to consist, at the outset of the government, will be sixty-five. Within three years a census is to be taken, when the number may be augmented to one for every thirty thousand inhabitants; and within every successive period of ten years, the census is to be renewed, and augmentations may continue to be made under the above limitation. It will not be thought an extravagant conjecture, that the first census will, at the rate of one for every thirty thousand, raise the number of representatives to at least one hundred. Estimating the negroes in 
fue premonitorio, pues en 1911 el número de representantes fue establecido, por ley, en $433 .{ }^{110}$ Este se incrementó a 435 cuando, de acuerdo con lo previsto por esa misma ley, se incorporaron como nuevos estados Arizona y New Mexico. Desde entonces, la cantidad de representantes no ha variado. ${ }^{111}$

Madison contesta luego algunas objeciones que se le formularon a la Cámara de Representantes. Sostiene, entonces, que: (a) la cantidad de legisladores establecida originalmente es suficiente para que el Congreso ejerza las competencias que le asigna la Constitución; ${ }^{112}$ (b) el modo de elección popular permitirá que se elijan a quienes mejor representan los intereses de todos; ${ }^{113}$ (c) la Cámara irá aumentando el número de sus miembros a medida que crezca la población, lo que será medido por cada censo; ${ }^{114}(\mathrm{~d})$ el Congreso debe regular las elecciones de sus miembros, pues si esta facultad quedara en manos de las legislaturas estatales, ello podría poner en crisis todo el sistema; ${ }^{115}$ (e) la diver-

the proportion of three-fifths, it can scarcely be doubted, that the population of the United States will, by that time, if it does not already, amount to three millions. At the expiration of twenty-five years, according to the computed rate of increase, the number of representatives will amount to two hundred; and of fifty years, to four hundred. This is a number, which I presume will put an end to all fears arising from the smallness of the body. I take for granted here, what I shall, in answering the fourth objection, hereafter show, that the number of representatives will be augmented, from time to time, in the manner provided by the constitution. On a contrary supposition, I should admit the objection to have very great weight indeed" (El Federalista, $\mathrm{N}^{\circ} 55$ ).

110 Apportionment Act of 1911, Public Law 62-5; 37 Stat. 13.

111 Cuando el 86 Congreso (1959-1961) incorporó como estados a Alaska y Hawaii, el número se incrementó temporalmente a 437, pero luego del censo de 1960 y de la elección de 1962, se redujo nuevamente a 435.

112 El Federalista ( $\left.\mathrm{N}^{\circ} 56\right)$.

113 "Who are to be the electors of the federal representatives? Not the rich, more than the poor; not the learned, more than the ignorant; not the haughty heirs of distinguished names, more than the humble sons of obscure and unpropitious fortune. The electors are to be the great body of the people of the United States. They are to be the same who exercise the right in every state of electing the correspondent branch of the legislature of the state. Who are to be the objects of popular choice? Every citizen whose merit may recommend him to the esteem and confidence of his country. No qualification of wealth, of birth, of religious faith, or of civil profession, is permitted to fetter the judgment, or disappoint the inclination of the people" (El Federalista, $\mathrm{N}^{\circ} 57$ ).

114 "Within every successive term of ten years, a census of inhabitants is to be repeated. The unequivocal objects of these regulations are, first, to re-adjust, from time to time, the apportionment of representatives to the number of inhabitants; under the single exception, that each state shall have one representative at least: secondly, to augment the number of representatives at the same periods; under the sole limitation, that the whole number shall not exceed one for every thirty thousand inhabitants. If we review the constitutions of the several states, we shall find that some of them contain no determinate regulations on this subject; that others correspond pretty much on this point with the federal constitution; and that the most effectual security in any of them is resolvable into a mere directory provision" (El Federalista, $\mathrm{N}^{\circ} 58$ ).

115 "Nothing can be more evident, than that an exclusive power of regulating elections for the national 


\section{sidad de intereses y opiniones existentes en el Gobierno federal evitará que cualquier estado pueda ser excluido de ella; ${ }^{116}$ (f) no era necesario establecer expresamente que las elecciones se llevaran a cabo en cada condado, ${ }^{117}$ del mis- mo modo que tampoco era necesario establecer en la Constitución que todas las elecciones deben llevarse a cabo el mismo día. ${ }^{118}$}

government, in the hands of the state legislatures, would leave the existence of the union entirely at their mercy $[. .$.$] with regard to the federal house of representatives, there is intended to be a general$ election of members once in two years. If the state legislatures were to be invested with an exclusive power of regulating these elections, every period of making them would be a delicate crisis in the national situation; which might issue in a dissolution of the union, if the leaders of a few of the most important states should have entered into a previous conspiracy to prevent an election" (El Federalista, $\mathrm{N}^{\circ} 59$ ).

116 "The dissimilarity in the ingredients, which will compose the national government, and still more in the manner in which they will be brought into action in its various branches, must form a powerful obstacle to a concert of views, in any partial scheme of elections. There is sufficient diversity in the state of property, in the genius, manners, and habits of the people of the different parts of the union, to occasion a material diversity of disposition in their representatives towards the different ranks and conditions in society. And though an intimate intercourse under the same government, will promote a gradual assimilation of temper and sentiment, yet there are causes, as well physical as moral, which may, in a greater or less degree, permanently nourish different propensities and inclinations in this particular. But the circumstance which will be likely to have the greatest influence in the matter, will be the dissimilar modes of constituting the several component parts of the government" (El Federalista, $\mathrm{N}^{\circ} 60$ ).

117 "The more candid opposers of the provision, contained in the plan of the convention, respecting elections, when pressed in argument, will sometimes concede the propriety of it; with this qualification, however, that it ought to have been accompanied with a declaration, that all elections should be held in the counties where the electors reside. This, say they, was a necessary precaution against an abuse of the power. A declaration of this nature would certainly have been harmless: so far as it would have had the effect of quieting apprehensions, it might not have been undesirable. But it would, in fact, have afforded little or no additional security against the danger apprehended; and the want of it will never be considered, by an impartial and judicious examiner, as a serious, still less as an insuperable objection to the plan. The different views taken of the subject in the two preceding papers, must be sufficient to satisfy all dispassionate and discerning men, that if the public liberty should ever be the victim of the ambition of the national rulers, the power under examination, at least, will be guiltless of the sacrifice" (El Federalista, $\mathrm{N}^{\circ} 61$ ).

118 "Uniformity, in the time of elections, seems not less requisite for executing the idea of a regular rotation in the senate; and for conveniently assembling the legislature at a stated period in each year. It may be asked, why then could not a time have been fixed in the constitution? As the most zealous adversaries of the plan of the convention in this state, are in general not less zealous admirers of the constitution of the state, the question may be retorted, and it may be asked, why was not a time for the like purpose fixed in the constitution of this state? No better answer can be given, than that it was a matter which might safely be intrusted to legislative discretion; and that, if a time had been appointed, it might, upon experiment, have been found less convenient than some other time. The same answer may be given to the question put on the other side. And it may be added, that the supposed danger of a gradual change being merely speculative, it would have been hardly advisable upon that speculation to establish, as a fundamental point, what would deprive several states of the convenience of having the elections for their own governments, and for the national government, at the same epoch" (El Federalista, №61). 
Al analizar el Senado, Madison se ocupa, en primer lugar, de justificar los requisitos para ser senador, más exigentes que los de los representantes, pues -según dice- en el Senado se requiere más experiencia y madurez. ${ }^{119}$ En segundo lugar, explica que la elección de los senadores por parte de las legislatura locales tiene la ventaja de que los estados intervienen en la formación de un órgano del Gobierno federal, generando un vínculo entre ambos sistemas. ${ }^{120}$ En tercer lugar, analiza la igualdad de senadores para todos los estados. Aquí se advierte su disgusto con el Gran Compromiso llevado a cabo en la Convención. En su opinión, cada distrito debería tener una representación proporcional, sin embargo, admite que una combinación de representación proporcional con representación igualitaria no está totalmente exenta de razón. ${ }^{121}$ En cuarto lugar, analiza la duración del mandato de los senadores, pero antes de ello se encarga de justificar la existencia misma del Senado. Sostiene básicamente que esta segunda cámara obra como un doble control, ${ }^{122}$ aquieta las pasiones, ${ }^{123}$ ofrece mayor continuidad en la tarea legislativa ${ }^{124}$ frente a la natural mutabilidad de opiniones que se producen en un

119 "The propriety of these distinctions, is explained by the nature of the senatorial trust; which, requiring greater extent of information and stability of character, requires, at the same time, that the senator should have reached a period of life most likely to supply these advantages; and which, participating immediately in transactions with foreign nations, ought to be exercised by none who are not thoroughly weaned from the prepossessions and habits incident to foreign birth and education" (El Federalista, $\mathrm{N}^{\circ} 62$ ).

120 "It is recommended by the double advantage of favouring a select appointment, and of giving to the state governments such an agency in the formation of the federal government, as must secure the authority of the former, and may form a convenient link between the two systems" (El Federalista, № 62).

121 "If indeed it be right, that among a people thoroughly incorporated into one nation, every district ought to have a proportional share in the government; and that among independent and sovereign states bound together by a simple league, the parties, however unequal in size, ought to have an equal share in the common councils, it does not appear to be without some reason, that in a compound republic, partaking both of the national and federal character, the government ought to be founded on a mixture of the principles of proportional and equal representation" (El Federalista, $\mathrm{N}^{\circ} 62$ ).

122 "[...] a senate, as a second branch of the legislative assembly, distinct from, and dividing the power with, a first, must be in all cases a salutary check on the government. It doubles the security to the people, by requiring the concurrence of two distinct bodies in schemes of usurpation or perfidy, where the ambition or corruption of one would otherwise be sufficient" (El Federalista, $\mathrm{N}^{\circ} 62$ ).

123 "The necessity of a senate is not less indicated by the propensity of all single and numerous assemblies, to yield to the impulse of sudden and violent passions, and to be seduced by factious leaders into intemperate and pernicious resolutions" (El Federalista, $\mathrm{N}^{\circ} 62$ ).

124 "It is not possible that an assembly of men, called, for the most part, from pursuits of a private nature, continued in appointment for a short time, and led by no permanent motive to devote the intervals of public occupation to a study of the laws, the affairs, and the comprehensive interests of their country, should, if left wholly to themselves, escape a variety of important errors in the exercise of their legislative trust (El Federalista, $\mathrm{N}^{\circ} 62$ ). 
cuerpo - como la Cámara de Representantes, que cambia sus miembros cada dos años- ${ }^{125}$ y otorga carácter nacional al Gobierno frente a las potencias extranjeras. ${ }^{126}$ Todas estas recomendaciones hacen recordar la conocida anécdota del desayuno entre Washington y Jefferson, a la que ya me he referido. ${ }^{127}$ Explica luego, en los $\mathrm{N}^{\circ}$ 64, 65 y 66, por qué se le ha encomendado al Senado que preste el acuerdo para la celebración de tratados y lleve a cabo el juicio político. En relación con lo primero, destaca la importancia de esta tarea, señalando que debe ofrecer las mayores seguridades y estar en manos de los más calificados. Todo ello se garantiza con el sistema de la Constitución, pues el presidente, que celebra el tratado, está elegido por el colegio electoral, compuesto por un grupo de notables, y el Senado, que da el acuerdo, es elegido por las legislaturas locales. ${ }^{128}$ Sobre el juicio político, dice que ningún otro órgano de Gobierno podría llevarlo a cabo. Descarta, incluso, a la Corte Suprema, en tanto no posee el "crédito y autoridad suficiente". ${ }^{29}$ Dice, asimismo, que el juicio político es discrecional y que la ausencia de un jurado exige que el tribunal sea numeroso. ${ }^{130}$ Por último, explica que esta función jurisdiccional encomendada

125 "The mutability in the public councils, arising from a rapid succession of new members, however qualified they may be, points out, in the strongest manner, the necessity of some stable institution in the government. Every new election in the states, is found to change one half of the representatives. From this change of men must proceed a change of opinions; and from a change of opinions, a change of measures. But a continual change even of good measures is inconsistent with every rule of prudence, and every prospect of success" (El Federalista, $\mathrm{N}^{\circ} 62$ ).

126 "[...] a sense of national character may be, it is evident that it can never be sufficiently possessed by a numerous and changeable body. It can only be found in a number so small, that a sensible degree of the praise and blame of public measures may be the portion of each individual; or in an assembly so durably invested with public trust, that the pride and consequence of its members may be sensibly incorporated with the reputation and prosperity of the community" (El Federalista, $\mathrm{N}^{\circ} 63$ ).

127 Ver nota 79.

128 "The power of making treaties is an important one, especially as it relates to war, peace, and commerce; and it should not be delegated but in such a mode, and with such precautions, as will afford the highest security, that it will be exercised by men the best qualified for the purpose, and in the manner most conducive to the public good. The convention appear to have been attentive to both these points: they have directed the president to be chosen by select bodies of electors, to be deputed by the people for that express purpose; and they have committed the appointment of senators to the state legislatures. This mode has, in such cases, vastly the advantage of elections by the people in their collective capacity, where the activity of party zeal, taking advantage of the supineness, the ignorance, the hopes, and fears of the unwary and interested, often places men in office by the votes of a small proportion of the electors" (El Federalista, $\mathrm{N}^{\circ}$ 64).

129 Se nota en esta opinión que la Corte Suprema no tenía todavía el peso institucional que fue adquiriendo luego.

130 "The convention, it appears, thought the senate the most fit depository of this important trust [...] Where else, than in the senate, could have been found a tribunal sufficiently dignified, or 
a un cuerpo legislativo no afecta la separación de poderes, en tanto es parte de los controles de la legislatura sobre el ejecutivo. Destaca también que los diferentes roles asignados a ambas cámaras establecen un equilibrio entre ellas y evitan la parcialidad en la decisión. ${ }^{131}$

\title{
5. Los años formativos (1789-1829) \\ 5.1. El inicio
}

\begin{abstract}
Ratificada la Constitución el 21 de junio de 1788 y elegido George Washington como presidente el 4 de febrero de $1789,{ }^{132}$ se convino que el Congreso
\end{abstract}

sufficiently independent? What other body would be likely to feel confidence enough in its own situation, to preserve, unawed and uninfluenced, the necessary impartiality between an individual accused, and the representatives of the people, his accusers? [...] Could the supreme court have been relied upon as answering this description? It is much to be doubted whether the members of that tribunal would, at all times, be endowed with so eminent a portion of fortitude, as would be called for in the execution of so difficult a task; and it is still more to be doubted, whether they would possess the degree of credit and authority, which might, on certain occasions, be indispensable towards reconciling the people to a decision that should happen to clash with an accusation brought by their immediate representatives. A deficiency in the first, would be fatal to the accused; in the last, dangerous to the public tranquillity. The hazard in both these respects could only be avoided, if at all, by rendering that tribunal more numerous than would consist with a reasonable attention to economy. The necessity of a numerous court for the trial of impeachments, is equally dictated by the nature of the proceeding. This can never be tied down by such strict rules, either in the delineation of the offence by the prosecutors, or in the construction of it by the judges, as in common cases serve to limit the discretion of courts in favour of personal security. There will be no jury to stand between the judges, who are to pronounce the sentence of the law, and the party who is to receive or suffer it. The awful discretion which a court of impeachments must necessarily have, to doom to honour or to infamy the most confidential and the most distinguished characters of the community, forbids the commitment of the trust to a small number of persons" (El Federalista, $\mathrm{N}^{\circ} 63$ ).

131 "This partial intermixture is even, in some cases, not only proper, but necessary to the mutual defence of the several members of the government, against each other. An absolute or qualified negative in the executive, upon the acts of the legislative body, is admitted by the ablest adepts in political science, to be an indispensable barrier against the encroachments of the latter upon the former. And it may, perhaps, with not less reason, be contended, that the powers relating to impeachments are, as before intimated, an essential check in the hands of that body, upon the encroachments of the executive. The division of them between the two branches of the legislature, assigning to one the right of accusing, to the other the right of judging, avoids the inconvenience of making the same persons both accusers and judges; and guards against the danger of persecution, from the prevalency of a factious spirit in either of those branches. As the concurrence of two-thirds of the senate will be requisite to a condemnation, the security to innocence, from this additional circumstance, will be as complete as itself can desire" (El Federalista, $\mathrm{N}^{\circ} 63$ ).

132 Washington fue electo por unanimidad, con el voto de 69 electores, y John Adams fue electo vicepresidente con 34 votos. Los resultados recién se conocieron el 6 de abril y Washington tomó posesión del cargo el 30 de ese mes. 
comenzaría sus sesiones un mes más tarde, el 4 de marzo, una vez concluidas las elecciones de senadores y representantes. El lugar de reunión fue el Federal Hall de la ciudad de New York, ${ }^{133}$ por entonces capital de la nación. ${ }^{134}$

El día previsto para el inicio solo habían llegado a New York 13 de los 30 representantes necesarios para el quorum, de modo que fue necesario esperar casi un mes para que pudiera comenzar la primera sesión del House of Representatives, que tuvo lugar el 1 de abril. ${ }^{135}$ Ese mismo día, Frederick A. C. Muhlenberg, de Pennsylvania, fue elegido Speaker of the House y al día siguiente fue designada una comisión de 11 miembros para redactar las reglas de procedimiento que fueron aprobadas el 7 de abril. La primera comisión permanente, el Committee on Elections, compuesta de 7 miembros, fue elegida el 13 de ese mes con el propósito de examinar las credenciales de los representantes. El día 18 fueron aceptadas 49 credenciales y el House pudo comenzar sus tareas debatiendo una ley aduanera.

Inicialmente, las reglas de procedimiento del House fueron tomadas de las prácticas parlamentarias inglesas. El Speaker dirigía el debate, estaba encargado de preservar el decoro y el orden de las exposiciones y anunciaba el resultado de las votaciones. Las comisiones de 3 miembros eran elegidas por el Speaker; y las de mayor número, por elección entre los representantes. Ningún miembro del House podía hablar más de dos veces en un mismo asunto, solo podían votar quienes estaban presentes -salvo causa justificada- y debían abstenerse los que tenían un interés personal en el asunto. Era usual también que en el tratamiento de las leyes más importantes el House se reuniera como una comisión del pleno (Committee of the Whole House), en cuyo caso la presidencia no la ejercía el Speaker. Se aprobaban allí los lineamientos generales de la ley, luego se designaba una comisión especial (select committee) para que redactara el proyecto $^{136} \mathrm{y}$, una vez cumplida esta tarea, se informaba el resultado a la comi-

133 En ese mismo lugar se había reunido el Congreso de la Ley de Sellos en 1765. Para esta ocasión, el edificio había sido renovado íntegramente por el arquitecto francés Pierre-Charles L’Enfant. Había peleado como voluntario en la Guerra de la Independencia y luego fue el encargado del diseño de Washington D.C. Ver Rimini (2006, p. 10).

134 En diciembre de 1790, la capital se mudó a Philadelphia, donde el Congreso sesionó en el llamado Congress Hall, hasta que, en noviembre de 1800, se instaló en la flamante Washington D.C., creada como distrito federal por la Residence Act de 1790. Las sesiones comenzaron en el Capitolio (U.S Capitol), cuya primera parte ya estaba terminada en esa época.

135 El mal tiempo y el peor estado de los caminos habían demorado a los representantes que venían de los estados más lejanos (Rimini, 2006, p. 12).

136 Del mismo modo que en el Parlamento británico, esta comisión no era permanente, sino que se disolvía una vez cumplida su tarea. 
sión del pleno, que debatía la ley cláusula por cláusula. Luego de ello, el House se reunía como tal, el Speaker retomaba la presidencia, se aprobaban o rechazan las enmiendas introducidas por la comisión del pleno, luego se hacía una tercera lectura de la ley y se votaba la aprobación del texto. ${ }^{137}$ La práctica de elegir una comisión especial para el tratamiento de cada proyecto de ley, que luego se disolvía una vez concluido el trámite legislativo de ese proyecto, fue abandonándose a medida que el House fue creciendo en número ${ }^{138}$ y los asuntos a tratar fueron aumentando. Las comisiones especiales (select committees) fueron remplazadas paulatinamente por comisiones permanentes (standing committees). ${ }^{139}$

Tampoco el Senado pudo reunirse el 4 de marzo. Ese día habían llegado a New York solamente 8 senadores de los 22 que por entonces lo integraban. ${ }^{140}$ La primera sesión tuvo lugar el 6 de abril, 5 días después de haberse reunido el House. Por aquel entonces, el rol del Senado estaba por definirse. Había nacido, como vimos, del Great Compromise, que permitió sancionar la Constitución y no se sabía si debía actuar como revisor de las leyes sancionadas por el House o bien como un consejo asesor del presidente en la celebración de tratados internacionales, una función que en la práctica nunca ejerció. ${ }^{141}$ Algunos lo veían, incluso, como una amenaza a los principios republicanos, considerándolo una suerte de House of Lords americana, un sentimiento que alimentaban algunos senadores pretendiendo tener superioridad institucional sobre los representantes.

Del mismo modo que el House, en su primera sesión el Senado aprobó sus reglas de procedimiento, en la cuales John Adams, como presidente del cuerpo, se aseguró una amplia discreción y un control total. Las primeras sesiones del Senado se celebraron a puertas cerradas. Recién se permitió el acceso del público en 1794. Tampoco existía por entonces un diario de sesiones ni un espacio especial para la prensa, que recién fue creado en 1802. De todos modos, en es-

137 Por aquel entonces no existían límites temporales para exponer, lo que alargaba extraordinariamente los debates.

138 Luego del censo de 1790, su número creció a 106 y aumentó a 142 en 1800.

139 En 1795 ya había cuatro comisiones permanentes y entre 1802 y 1809 se agregaron seis más. Las más importantes fueron las de Comercio e Industria (Commerce and Manufactures), Presupuesto y Gasto Público (Ways and Means) y Tierras Públicas (Public Lands), creada en 1805 a propósito de la compra de la Louisiana francesa.

140 En ese momento, la Constitución había sido ratificada por once estados. Faltaban North Carolina, que la ratificó en noviembre de 1789, y Rhode Island, que lo hizo en mayo de 1790.

141 De hecho, cuando el 22 de agosto de 1789 Washington quiso valerse del acuerdo del Senado para celebrar un tratado con tribus indígenas, su presencia en el recinto, junto con Henry Knox, el secretario de Guerra, no fue bien recibida. 
tos años iniciales, el Senado no tuvo una gran carga de tareas, pues la gran mayoría de las leyes se originaron en el House. ${ }^{142}$ Las leyes no eran analizadas por comisiones permanentes, sino por comisiones creadas específicamente para un caso determinado y, concluida su tarea, se disolvían.

Pese a la necesidad de organizarse desde lo más básico y elemental, durante la sesión del primer año (1789), el Congreso estuvo muy activo. El 15 de mayo fueron distribuidos, por primera vez, los senadores en las tres clases que establece la sección del artículo I de la Constitución. ${ }^{143}$ El 8 de junio, James Madison introdujo el proyecto del Bill of Rights en el House; ${ }^{144}$ en julio, el Congreso organizó el primer departamento ejecutivo (ministerio), que en septiembre fue denominado State Department; ${ }^{145}$ en agosto fue organizado el Ministerio de Guerra (War Department); en septiembre; el Ministerio de Economía (Treasury Department) ${ }^{146}$ y el 24 de ese mes fue sancionada la primera Judiciary Act, que organizó la justicia federal y creó la Corte Suprema. ${ }^{147}$

Con el paso del tiempo, cada cámara iría adquiriendo su propia fisonomía, marcada en buena medida por el modo en que se componían. Mientras el House aumentaba numéricamente muy rápido, a impulsos del crecimiento de la población, el Senado lo hacía en forma lenta y esporádica, con el ingreso de cada estado. El mayor número de representantes obligó a que en el House

142 Durante los veinte primeros años (1789-1809), el 78\% de las leyes se originó en el House (Conf. Guide to Congress, 2015, p. 104).

143 Según esta cláusula constitucional, "Tan pronto como se hayan reunido en virtud de la elección inicial, [los senadores] se dividirán en tres grupos tan iguales como sea posible. Las bancas de los senadores del primer grupo quedarán vacantes al terminar el segundo año; las del segundo grupo, al expirar el cuarto año y las del tercer grupo, al concluir el sexto año, de tal manera que se pueda elegir una tercera parte cada dos años, y si se producen vacantes, por renuncia u otra causa, durante el receso de la legislatura de algún Estado, el Poder Ejecutivo [de dicho estado] podrá hacer designaciones provisionales hasta el siguiente período de sesiones de la legislatura, la que cubrirá dichas vacantes" ("Immediately after they shall be assembled in Consequence of the first Election, they shall be divided as equally as may be into three Classes. The Seats of the Senators of the first Class shall be vacated at the Expiration of the second Year, of the second Class at the Expiration of the fourth Year, and of the third Class at the Expiration of the sixth Year, so that one third may be chosen every second Year; and if Vacancies hap pen by Resignation, or otherwise, during the Recess of the Legislature of any State, the Executive thereof may make temporary Appointments until the next Meeting of the Legislature, which shall then fill such Vacancies").

144 El 25 de septiembre fueron sancionadas doce enmiendas por el Congreso y 2 años después, el 15 de diciembre de 1791, entraron en vigencia las diez primeras enmiendas con la ratificación otorgada por Virginia.

145 Thomas Jefferson fue designado secretario de Estado el 26 de septiembre.

146 El 11 de septiembre, Alexander Hamilton fue designado secretario del Tesoro.

147 John Jay fue elegido Chief Justice el 26 de septiembre y la Corte Suprema se reunió, por primera vez, el 2 de febrero de 1790 . 
sus miembros se restringieran en el uso de la palabra, delegaran muchas de sus funciones en las comisiones y crearan diversas técnicas para mantener fluido el paso de la legislación. El Senado, en cambio, mucho más pequeño en número, en el que cada senador se sentía un embajador de su estado, estas limitaciones de tiempo no fueron acuciantes. En el House, el objetivo principal fue la decisión; en el Senado predominaba la deliberación.

\subsection{Los símbolos de ambas cámaras}

Siguiendo la tradición del Parlamento británico -tomada, a su vez, de los romanos-, ambas cámaras del Congreso eligieron inmediatamente los símbolos representativos de su autoridad.

El House, en su primera sesión, diseñó para ello un mazo (mace) cuyo portador sería el sergeant at arms, encargado de preservar el orden en el recinto. El mace es un haz de 13 varillas de ébano ${ }^{148}$ atadas con bandas de plata, que en su extremo superior tiene un globo terráqueo y encima de él un águila con las alas desplegadas, todo del mismo metal. Tiene una longitud de 46 pulgadas (117 centímetros). ${ }^{149}$ Cuando el House está en una sesión ordinaria, el mace está colocado en un pedestal a la derecha del escritorio del Speaker; en cambio, cuando se reúne como comisión de la Cámara en pleno, se lo ubica en un lugar más inferior. ${ }^{150}$

En el Senado no hay un mace, sino un gavel, que tiene una forma similar a la cabeza del martillo que emplean los jueces. Según la tradición, John Adams, para preservar el orden en el Senado, utilizó desde el comienzo un gavel de marfil de unas 2,5 pulgadas y existen registros de su uso desde 1831. El gavel original se desintegró, sin posibilidad de ser reparado, en $1954 .{ }^{151}$ Ese año, el Gobierno de la India, recientemente establecido luego de su independencia, le obsequió al Senado uno nuevo, que actualmente está en uso. ${ }^{152}$

148 Representan a los 13 estados originales.

149 El primer mace fue destruido por los británicos cuando en la Guerra de 1812 incendiaron el Capitolio. Hasta 1841 fue utilizado uno de madera y, ese año, William Adams, un platero de New York, hizo el que actualmente sigue en uso.

150 Ver: https://history.house.gov/Collection/Listing/2006/2006-162-000/.

151 Ya estaba muy deteriorado y parece ser que en una acalorada sesión en 1954, Richard Nixon, por entonces vicepresidente, lo usó con fuerza y lo terminó de romper.

152 Ver: https://www.senate.gov/artandhistory/history/minute/The_Senates_New_Gavel.htm. 


\subsection{Emergen los partidos políticos. Federalistas y demócrata-republicanos}

Si bien la Constitución no tenía -ni tiene- cláusula alguna sobre los partidos políticos, estos no tardaron en aparecer y cobrar forma a partir de las dos agrupaciones que habían antagonizado en torno a la sanción de la Constitución: los federalistas y los antifederalistas. Washington, como presidente, se mantuvo imparcial en este proceso, pero ambos partidos comenzaron a formarse dentro de su propio gabinete. Alexander Hamilton, un activo y eficiente secretario del Tesoro, se erigió rápidamente como líder de los federalistas y Thomas Jefferson, como secretario de Estado, encabezó la posición contraria, secundado por James Madison, quien lo sucedería en el cargo en 1801. Ambos ocuparían luego la presidencia durante dos períodos cada uno. ${ }^{153}$ Los federalistas, en cambio, perdieron a su líder tempranamente, cuando Hamilton falleció en 1804 a raíz de la herida fatal que tuvo en el duelo con Aaron Burr, por entonces vicepresidente de Jefferson. ${ }^{154}$ Esta separación entre los que favorecían a un Gobierno central fuerte de corte más elitista y quienes preferían una democracia agraria se hizo más evidente y profunda con motivo del antagonismo entre Inglaterra y Francia a raíz de la Revolución francesa. Hamilton y sus partidarios proponían una política de neutralidad, mientras que Jefferson sostenía el apoyo a los franceses.

Durante las presidencias de Washington (1789-1797) y de Adams (17971801), ambos partidos estuvieron equilibrados en el House, pero bajo las presidencias de Jefferson (1801-1809) y de Madison (1809-1817) los Jeffersonians ${ }^{155}$ superaron ampliamente en número a los federalistas. Algo similar ocurrió en el Senado, donde los federalistas tuvieron una ajustada mayoría hasta 1801. A partir de allí, esta declinó. De todos modos, la existencia de estos dos partidos iniciales sería breve. Madison fue sucedido por James Monroe (1817-1825), quien si bien pertenecía al mismo partido que sus predecesores, intentó borrar

153 Recordemos que si bien por aquel entonces la Constitución permitía la reelección presidencial sin límites, todos los presidentes siguieron la costumbre de Washington de retirarse luego de cumplido el segundo período. La limitación a dos períodos fue establecida recién por la Enmienda XII (sancionada en 1947 y ratificada en 1951), luego de que Franklin D. Roosevelt fuera reelegido tres veces (1936, 1940 y 1945).

154 El duelo fue con pistolas y, aparentemente, Hamilton disparó primero en dirección a un cedro, sin intentar herir a Burr. Este, en cambio, hirió mortalmente a Hamilton. La bala le penetró en el abdomen y se alojó cerca de la columna vertebral. Falleció al día siguiente. Un detallado relato del duelo y sus antecedentes puede verse en una de las principales biografías de Hamilton (Chernow, 2005, caps. 41 y 42).

155 En esta primera etapa, los partidos políticos no tuvieron una denominación uniforme u oficial. Los federalistas siempre fueron reconocidos por este nombre y los partidarios de Jefferson se llamaron demócrata-republicanos, aunque esta denominación nada tiene que ver con los actuales partidos Republicano y Demócrata. 
las diferencias partidarias mediante su política del good feeling, convencido de que el partisanismo era negativo. Sea como fuere, ambos partidos prácticamente dejaron de existir hacia 1825. Tal como veremos más adelante, los federalistas se extinguieron y los demócrata-republicanos se dividieron en "demócratas" y whigs, los dos partidos que se disputaron el poder desde 1829 hasta la fundación del Partido Republicano, en 1854.

\subsection{El reparto del poder entre el Ejecutivo y el Congreso}

Durante los primeros veinte años (1789-1809), el Ejecutivo dominó el Congreso. Las figuras de Jefferson y Hamilton ejercieron una influencia tal en sus partidos que no permitieron el nacimiento de liderazgos legislativos fuertes. ${ }^{156}$ A lo largo de este período, los diferentes Speakers se comportaron en el House como portavoces de sus partidos, y cuando alguna figura elegida por el propio presidente no seguía sus mandatos, era inmediatamente removida del cargo que se le había asignado. ${ }^{157}$ Por su lado, Albert Gallatin, quien bajo el Gobierno de Jefferson sucedió a Hamilton en la Secretaría del Tesoro, continuó con la costumbre de su predecesor de influir con su política en el House. De modo tal que si bien en estas dos primeras décadas se fue institucionalizando el trabajo de las comisiones legislativas y la elección de un líder de la mayoría, todo ello se hizo bajo un estricto control del Ejecutivo.

\subsection{Nuevos líderes legislativos. Henry Clay y Daniel Webster}

Con la llegada de Madison a la presidencia, en 1809, esta tendencia se revirtió. Pese a que había liderado intelectualmente la Convención constituyente y había ejercido luego ocho años como secretario de Estado bajo Jefferson, durante su mandato presidencial Madison perdió el control sobre el Congreso que habían ejercido sus antecesores. Una nueva generación de políticos más jóvenes, a quienes John Randolph llamaba war hawks (halcones de guerra), pues propiciaron la guerra de 1812 contra Gran Bretaña, tomaron el control de Partido De-

156 Como gesto formal para que esta influencia fuera menos notoria, Jefferson inauguró la costumbre de no asistir a la inauguración de la sesiones del Congreso, enviando en su reemplazo a un asistente que leía su mensaje. Esta tradición se mantuvo hasta que Woodrow Wilson (1913-1921) la abandonó.

157 Este fue el caso de John Randolph, a quien Jefferson había elegido como líder en el recinto y presidente de la comisión de presupuesto (Ways and Means Committee). Sin embargo, Randolph entró en conflicto con Jefferson sobre la adquisición de Florida y fue destituido de su cargo en la comisión de presupuesto. 
mócrata-Republicano a expensas de las debilidades de Madison. Esta ausencia de influencia ejecutiva sobre el Congreso se mantuvo durante las dos décadas siguientes, hasta la presidencia de Andrew Jackson. ${ }^{158}$ Dentro de esta segunda generación de políticos, que sucedió a los Founding Fathers, se destacaron, entre otros, Henry Clay y Daniel Webster. ${ }^{159}$

Henry Clay era, indudablemente, un hombre de acción. Nacido en Virginia, se estableció desde joven en Kentucky, estado al cual representó en el Congreso. En la política nacional comenzó su carrera como senador por su estado de adopción en $1810,{ }^{160}$ donde se hizo notar por su exhortación a formar una "nueva raza de héroes" y su propuesta de luchar contra Canadá. ${ }^{161}$ De hecho, fue uno de los que impulsó la declaración de guerra contra Inglaterra, que dio lugar a la Guerra de 1812, y luego fue el jefe de la delegación que negoció el tratado de paz (Treaty of Ghent) en 1814. Representaba con ello un nuevo nacionalismo encendido por la interferencia británica en el comercio de los Estados Unidos. Su actividad como senador en esta primera etapa de su vida fue breve. Su carrera política se desarrolló como miembro del House, donde ingresó como representante de Kentucky en 1811. Merced a su elocuencia y personalidad, fue rápidamente elegido Speaker, posición para la que fue reelegido 6 veces, ocupando el cargo por espacio de más de 10 años. ${ }^{162}$ Desde allí dominó la Cámara, poniendo en las comisiones legislativas a sus war hawks. Todo ello le permitió convertirse en el líder del Partido Demócrata-Republicano. Luego fue secretario de Estado entre 1825 y 1829 durante la presidencia de John Quincy Adams y, más tarde, retornó al Senado ocupando una banca en 1831-1842 y 1849-1852.

Una carrera similar fue la de Daniel Webster, aunque tal vez sea más recordado por su actividad como abogado y senador que como representante en el House. Había nacido en New Hampshire en 1782 y, a diferencia de Clay,

158 Los sucesores de Madison, James Monroe y John Quincy Adams, tampoco tuvieron el control de su partido. Este último, especialmente, le debía su cargo al acuerdo celebrado con Henry Clay, que era por entonces Speaker del House.

159 También pertenecen a esta generación otros políticos prominentes que ocuparon en este período bancas en el Senado, tales como Andrew Jackson, por Tennessee (1823-1825), Martin van Buren, por New York (1821-1828), William Henry Harrison, por Ohio (1825-1828) y John Tyler, que fue representante por Virginia (1816-1821) y luego senador por ese mismo estado (1827-1836). Todos ellos fueron luego presidentes de los Estados Unidos.

160 Antes, en 1807, había sido diputado y presidente de la Cámara de Representantes de Kentucky.

161 Decía que con la milicia de Kentucky era suficiente para poner Montreal y el Alto Canadá a los pies de los Estados Unidos ("the militia of Kentucky are alone competent to put Montreal and the Upper Canada at your feet”). Vid. Mayo (1937, pp. 346-347).

162 Tenía 34 años cuando fue elegido la primera vez y fue el Speaker más joven 
militaba en las filas federalistas, a las que representó en el House como diputado por su estado natal en 1813-1817. Luego volvería a ocupar una banca allí en 1823-1827, por Massachusetts. Durante este período, combinó su actividad legislativa con el intenso ejercicio de la abogacía, representando los intereses de su partido en casos clave ante la Corte Suprema, donde los federalistas conservaban un fuerte bastión defendido por el Chief Justice John Marshall. Son famosos sus éxitos en leading cases como McCulloch $v$. Maryland, ${ }^{163}$ en el que se declaró la constitucionalidad de la creación del segundo Banco de los Estados Unidos; Trustees of Dartmouth College v. Woodward, ${ }^{164}$ en el cual se hizo valer la cláusula contractual frente a la interferencia legislativa de New Hampshire en una institución educativa privada; y Gibbons v. Ogden, ${ }^{165}$ en el que fue establecido que el Congreso tiene competencia exclusiva para regular el comercio interestatal. En 1827, Webster fue electo senador por Massachusetts y tuvo que dejar su banca en el House con cierta reticencia, pues había sentado allí sus reales desempeñándose como presidente de la Comisión de Asuntos Judiciales (House Judiciary Committee). Fue reelecto como senador hasta 1841, cuando fue designado secretario de Estado por el presidente William Harrison. En 1845 volvió al Senado hasta 1850, año en el que fue nuevamente designado secretario de Estado por el presidente Millard Fillmore. Murió en 1852 en ejercicio del cargo. Estando en el Senado, fue famoso su debate con el senador Robert Y. Hayne de South Carolina. Lo que comenzó siendo una discusión sobre tierras fiscales federales concluyó en un análisis integral del sistema federal. Hayne sostenía el derecho de anulación (nullification) de los estados, una posición propia de una confederación, mientras que Webster defendía la tesis de la Unión como estado soberano. ${ }^{166}$

Hacia el final de este período, cobró notoriedad John Caldwell Calhoun, de South Carolina, que fue el segundo vicepresidente de John Quincy Adams en 1825-1829 y luego el primer vicepresidente de Andrew Jackson en 1829-1832, sucedido por Martin Van Buren. Sus antecesores inmediatos en el cargo no se habían lucido. George Clinton, vicepresidente de Madison, era anciano, estaba débil y murió durante su mandato, al igual que su sucesor, Elbridge Gerry. Daniel Tompkins, exgobernador de New York y vicepresidente de Monroe, casi

\footnotetext{
16317 U.S. 316 (1819).

16417 U.S. 518 (1819).

16522 U.S. 1 (1824).

166 El debate está reproducido en Belz (2000). Por mi parte, lo he analizado con más detalle en Bianchi (2008, pp. 210-214).
} 
no concurrió a las sesiones, aquejado por problemas financieros y de salud. ${ }^{167}$ Calhoun, por el contrario, merced a su hostilidad con Adams y sus ambiciones presidenciales, revitalizó el cargo con el apoyo del senador Hayne -rival de Webster en el debate antes mencionado-, quien fue el vocero de sus decisiones. Durante las dos décadas siguientes, hasta su muerte en 1850, Calhoun fue un influyente senador, liderando la facción esclavista de los sureños.

\subsection{El crecimiento de las comisiones legislativas permanentes}

El fortalecimiento de ambas cámaras en este período fue acompañado de un crecimiento sustancial de las comisiones legislativas permanentes (standing committees). De acuerdo con la tradición heredada del Parlamento inglés, en un comienzo las leyes eran analizadas por comisiones ad hoc (select committees), que se disolvían una vez concluida su tarea. Durante ese período, esta costumbre fue abandonándose paulatinamente y se crearon numerosas comisiones permanentes con competencia específica, que se convirtieron en el foro principal para el análisis de los proyectos de leyes.

Así, en el House, de las 350 comisiones ad hoc existentes en el $3^{\circ}$ Congreso (1793-1795), solo quedaban 70 en el 13० Congreso (1813-1815), y las comisiones permanentes, que eran 10 en 1809 , crecieron a 20 en 1825 . Asimismo, en 1822 , una regla dictada por el House le otorgó a estas comisiones la facultad de reportar sus conclusiones directamente al pleno de la Cámara. Entre las comisiones permanentes creadas en el House durante este período, la más importante fue la de presupuesto y asuntos financieros (Committee of Ways and Means), creada en 1789 como una comisión especial (select committee) y convertida en permanente en $1802 .{ }^{168}$ Esta comisión es particularmente importante para el

167 Además de las numerosas biografías individuales sobe cada vicepresidente, puede verse Purcell (2001).

168 La resolución que crea el Committee of Ways and Means como una comisión permanente establece su competencia en estos términos: "It shall be the duty of the said Committee on Ways and Means to take into consideration all such reports of the U.S. Department of the Treasury, and all such propositions relative to the revenue, as may be referred to them by the House; to inquire into the state of the public debt, of the revenue, and of the expenditures, and to report, from time to time, their opinion thereon; to examine into the state of the several public departments, and particularly into the laws making appropriations of moneys, and to report whether the moneys have been disbursed conformably with such laws; and also to report, from time to time, such provisions and arrangements, as may be necessary to add to the economy of the departments, and the accountability of their officers". Ver: https://waysandmeans.house.gov/about/committee-history. Ver también: https://waysandmeans.house.gov/about/committee-history/appendix-ii-historical-note-committee-ways-and-means. 
House, ya que por mandato constitucional (artículo I, sección 7) las leyes impositivas deben iniciarse allí. Fueron creadas también, en 1822, las comisiones de Asuntos Militares, Asuntos Navales y Relaciones Internacionales. Antes de ello, en 1816, a instancias de Clay, fueron creadas seis comisiones sobre gasto público, una por cada Secretaría de Estado (ministerios) existentes en ese momento. Todas estas comisiones llevaron a cabo numerosas investigaciones en la década de 1816-1826, entre ellas, la de la conducta del general Andrew Jackson en la Seminole War y las de William Crawford como secretario del Tesoro y John Calhoun como secretario de Guerra. ${ }^{169}$

Aunque con menor intensidad, las comisiones permanentes también comenzaron a proliferar en el Senado. La tarea de nombrar una comisión para el tratamiento de cada proyecto de ley resultó agotadora ${ }^{170} \mathrm{y}$, como resultado, comenzó a extenderse en el Senado también la práctica de designar comisiones permanentes con competencia específica. Las primeras fueron creadas en diciembre de 1816. Entre ellas, las de Relaciones Exteriores, Finanzas, Comercio y Manufacturas, Asuntos Militares, Asuntos Navales, Milicia, Tierras Públicas, Reclamos, Justicia, Correo, Caminos y Pensiones. Inicialmente, estas comisiones tenían cinco miembros, pero ese número se incrementó a siete a mediados del siglo XIX y a nueve en $1900 .{ }^{171}$

\subsection{La Corte Suprema colabora para fortalecer al Congreso}

El fortalecimiento del Congreso durante este período recibió la ayuda de la Corte Suprema en tres fallos, dos de ellos ya mencionados en párrafos anteriores. Me refiero a McCulloch v. Maryland, ${ }^{172}$ en el que se reconoció que el Congreso tenía facultades implícitas, dentro de las cuales estaba la de crear un banco

169 Vid. Guide to Congress (2015, p. 41).

170 En la sesión de 1815-1816 se nombraron casi cien comisiones.

171 El modo de elegir a los miembros de estas comisiones fue variando de acuerdo a las conveniencias políticas de cada momento. Hasta 1823, eran elegidos por votación mediante boleta (ballot). Ese año se dispuso que serían elegidos por el presidente pro tempore del Senado. Durante 1825-1827, John Calhoun reasumió personalmente esa tarea como vicepresidente para designar en ellas a los partidarios de Andrew Jackson, en una clara maniobra para fastidiar al presidente John Quincy Adams. En 1828 se delegó nuevamente la tara en el presidente pro tempore y en 1833 se volvió al sistema de la votación por boleta.

17217 U.S. 316 (1819). 
federal; ${ }^{173}$ Gibbons v. Ogden, ${ }^{174}$ que le otorgó al Congreso facultades exclusivas para regular el comercio interjurisdiccional; y Brown v. Maryland, ${ }^{175}$ que ratificó lo anterior al declarar inconstitucional una ley de Maryland que exigía una licencia para vender, dentro de su territorio, productos importados, sosteniendo que si bien los estados tienen el poder de gravar a sus ciudadanos, ese poder no puede obstruir el ejercicio de facultades propias del Congreso. ${ }^{176}$

\subsection{La elección de 1824 y el nacimiento del Partido Demócrata}

A partir de la elección de 1816, los demócrata-republicanos, que ya dominaban por completo la escena política, comenzaron a dividirse entre los antiguos terratenientes y los nuevos pequeños granjeros que se habían incorporado a la vida política con la extensión del sufragio. Estos últimos encontraron un líder en el general Andrew Jackson, de Tennessee. Aguerrido y controvertido militar de numerosas batallas, ${ }^{177}$ Jackson compitió por la presidencia con John Quincy

173 'Although, among the enumerated powers of government, we do not find the word 'bank,' or 'incorporation,' we find the great powers to lay and collect taxes; to borrow money; to regulate commerce; to declare and conduct a war; and to raise and support armies and navies. The sword and the purse, all the external relations, and no inconsiderable portion of the industry of the nation, are entrusted to its government. It can never be pretended that these vast powers draw after them others of inferior importance, merely because they are inferior. Such an idea can never be advanced. But it may with great reason be contended, that a government, entrusted with such ample powers, on the due execution of which the happiness and prosperity of the nation so vitally depends, must also be entrusted with ample means for their execution. The power being given, it is the interest of the nation to facilitate its execution. It can never be their interest, and cannot be presumed to have been their intention, to clog and embarrass its execution by withholding the most appropriate means [...] If, indeed, such be the mandate of the constitution, we have only to obey; but that instrument does not profess to enumerate the means by which the powers it confers may be executed; nor does it prohibit the creation of a corporation, if the existence of such a being be essential to the beneficial exercise of those powers. It is, then, the subject of fair inquiry, how far such means may be employed" (17 U.S., pp. 407-408).

17422 U.S. 1 (1824).

17525 U.S. 419 (1827).

176 "It has been contended, that this construction of the power to regulate commerce, as was contended in construing the prohibition to lay duties on imports, would abridge the acknowledged power of a state to tax its own citizens, or their property within its territory. We admit this power to be sacred; but cannot admit that it may be used so as to obstruct the free course of a power given to Congress. We cannot admit that it may be used so as to obstruct or defeat the power to regulate commerce. It has been observed, that the powers remaining with the states may be so exercised as to come in conflict with those vested in Congress. When this happens, that which is not supreme must yield to that which is supreme" (25 U.S., p. 448).

177 Siendo muy joven, fue prisionero de los ingleses durante la Guerra de la Independencia, intervino luego en la Guerra de 1812, también contra los ingleses y participó en la guerra de 1817-1818 contra los indígenas de la tribu seminola, excediendo en varias oportunidades las instrucciones que había 
Adams (hijo de John Adams, el segundo presidente) en la reñida elección de 1824, siendo por entonces senador por Tennessee. ${ }^{178}$ Si bien Jackson había obtenido la mayoría de los votos populares, ninguno de los cuatro candidatos que se presentaron (los otros fueron Henry Clay y William H. Crawford) obtuvo mayoría en el colegio electoral, de modo que, bajo lo establecido en la Enmienda XII (sancionada en 1803 y ratificada en 1804), el House tuvo que dirimir la elección. Allí, la balanza se inclinó a favor de Adams, merced a un acuerdo que este había celebrado con Henry Clay, de Kentucky, el entonces Speaker, un ferviente oponente de Jackson, que luego fue designado secretario de Estado por Adams. Los partidarios de Jackson se alzaron furiosos, denunciando la existencia de un acuerdo corrupto entre Adams y Clay y se separaron del partido gobernante, fundando el actual Democratic Party, ${ }^{179}$ que llevó a Jackson a la presidencia en 1828 con un triunfo aplastante sobre Adams. El resto del partido, bajo el liderazgo de Henry Clay y Daniel Webster, pasó a llamarse Whig Party, ${ }^{180}$ que disputó el poder con los demócratas jacksonianos hasta extinguirse luego del nacimiento del Republican Party, en 1854, surgido, como veremos, como reacción espontánea contra la llamada "Ley Kansas-Nebraska".

\section{Whigs y demócratas hasta la Guerra Civil (1829-1861) \\ 6.1. Dos nuevos partidos}

Whigs y demócratas sucedieron, respectivamente, a los antiguos federalistas y a los demócrata-republicanos de la primera época, pero, curiosamente, intercambiaron en parte la filosofía política que originariamente había inspirado a cada partido. Los demócratas jacksonianos tomaron de su jefe político el presidencialismo fuerte, que otrora predicaban los federalistas. A su vez, los whigs propiciaban la supremacía legislativa, una bandera inicialmente enarbolada por los seguidores de Jefferson. No obstante ello, de sus antiguas raíces los whigs conservaron el interés por la protección de la industria y el comercio, mientras que los demócratas defendían los derechos de los estados y, fundamentalmente, la economía agraria basada en la esclavitud. Con este telón de fondo, ambos partidos dominaron -y se repartieron- la escena política durante los 30 años

recibido del presidente James Monroe.

178 Antes de ello había sido juez del superior tribunal de ese estado entre 1798 y 1804.

179 Sobre los orígenes del Democratic Party puede verse Cheathem (2018).

180 Sobre la historia del Whig Party en los Estados Unidos puede verse Holt (1999). 
que precedieron a la Guerra Civil, cuyos hechos más salientes son: la disputa por la esclavitud, la preeminencia del Senado, la fractura interna del House en dos mitades prácticamente iguales, los conflictos entre el Senado y el Ejecutivo y el nacimiento del Partido Republicano en 1854.

\subsection{Preeminencia del Senado sobre el House}

A lo largo de las tres décadas previas a la Guerra Civil, el Senado vivió una edad dorada. Si bien sus causas pueden ser numerosas, lo cierto es que contribuyeron a ello factores tales como la mayor experiencia política de sus miembros, su prestigio y su estabilidad en el cargo, fruto de la más prolongada duración de sus mandatos. Asimismo, la constante expansión territorial y la creación sucesiva de nuevos estados, cada uno de los cuales aportaba dos nuevos senadores, fue transformando al Senado de un cenáculo íntimo y reducido en un cuerpo político de gran peso, nutrido con las personalidades políticamente más destacadas de entonces. De hecho, en 1829, al comienzo del primer mandato de Jackson, el Senado tenía 48 miembros, y hacia el final del gobierno de Buchanan, en 1861, había alcanzado los 66. Por el contrario, el House, luego de alcanzar los 242 representantes en 1833, no incrementó el número de representantes durante los cuarenta años siguientes. ${ }^{181}$

Además de Daniel Webster y Henry Clay, a los que ya hice mención, se destacaron en este período, entre otros, John C. Calhoun, de South Carolina (1832-1843 y 1845-1850), que había sido vicepresidente bajo John Quincy Adams (1825-1829) y Andrew Jackson (1829-1832) y fue luego secretario de Estado con John Tyler (1844-1845); Thomas Hart Benton, de Missouri, que representó allí a los demócratas durante treinta años (1821-1851); Lewis Cass, demócrata de Michigan (1849-1857); Samuel Houston, demócrata de Texas, uno de los dos primeros senadores de su estado (1846-1859), cuyo nombre lleva la conocida ciudad; Jefferson F. Davis y Henry S. Foote, demócratas de Mississippi que luego se volcaron a la causa de los confederados; William H. Seward, de New York (1849-1861), que fuera primero whig y luego republicano; Stephen Douglas, de Illinois (1847-1861), quien entre agosto y octubre de 1858 mantuvo con Lincoln los célebres debates sobre la esclavitud en siete ciudades de ese estado; y Charles Sumner, de Massachusetts (1851-1874), gran orador y ferviente antiesclavista. ${ }^{182}$

181 Recién alcanzó los 292 miembros en el 43 Congreso (1873-1875).

182 Su enérgica prédica antiesclavista lo convirtió en víctima de uno los hechos más deplorables y violentos que hayan tenido lugar en el Senado. En mayo de 1856 estaba ardiente la discusión acerca de si 


\subsection{Los conflictos de Jackson con el Senado}

La pérdida de poder político que había sufrido el Ejecutivo con Madison fue recobrada bajo el Gobierno de Jackson. Apoyado por mayorías populares y dotado de una fuerte personalidad, el nuevo presidente no tardó en ejercer una gran influencia sobre el House, pero encontró, paralelamente, una fuerte oposición en los senadores del joven Partido Whig, representantes de intereses industriales y comerciales y, sobre todo, sostenedores del principio de supremacía legislativa, que no tardaron en cuestionar el ejercicio de la prerrogativa presidencial. Entre otras controversias, una de las más notables tuvo lugar en 1834, cuando Jackson dispuso de fondos depositados en el Banco de los Estados Unidos y se negó a entregarle al Senado los documentos que sobre este asunto había intercambiado con miembros de su gabinete. Impulsada por Henry Clay, el Senado emitió entonces una resolución censurando la decisión presidencial, que no tardó en ser respondida por un mensaje de Jackson cuestionando la competencia del Senado para emitirla, en tanto -sostuvo- se trataba de cargos propios de un juicio político (impeachment), que solo podía ser promovido por el House. Todo ello dio lugar a una larga disputa, en la cual el senador Thomas Benton ejerció una fuerte influencia para derogar la resolución, lo que finalmente tuvo lugar hacia 1837, ya sobre el final del segundo mandato de Jackson, cuando los demócratas jacksonianos habían logrado el control del Senado.

\subsection{Los whigs contra Tyler}

Estas disputas entre los senadores whigs y el presidente continuaron bajo el Gobierno de John Tyler (1841-1845). A Jackson lo sucedió Martin Van Buren (1837-1841), demócrata también, y este fue sucedido, a su vez, por William Harrison, del Partido Whig, fuertemente apoyado por Daniel Webster y Henry Clay. Con Harrison, los whigs pensaron que tenían asegurado el control

Kansas debía ser admitido como un estado libre o esclavista. Durante un encendido discurso para que fuera declarado un estado libre, Sumner se dirigió en términos muy duros contra los senadores Stephen Douglas, de Illinois, y Andrew Butler, de South Carolina. Tres días después, el 22 de mayo, luego de concluida la sesión, entró en el recinto del Senado Preston S. Brooks, representante de South Carolina, y, sin decir palabra, comenzó a golpear a Sumner en la cabeza con un bastón con puntera de metal hasta dejarlo sangrando e inconsciente, sin que nadie fuera capaz de detener la agresión. Como todo castigo, Brooks fue removido de su banca, aunque luego fue reelegido. Dada la gravedad de sus heridas, Sumner tardó casi tres años en regresar al Senado. Tal como veremos luego, en 1867 Sumner fue uno de los artífices de la aprobación en el Senado de la compra de Alaska. Ver https://www.senate. gov/artandhistory/history/minute/The_Caning_of_Senator_Charles_Sumner.htm. 
político, ${ }^{183}$ pero, para su desgracia, Harrison falleció un mes después de haber asumido y fue sucedido por Tyler, su vicepresidente, otrora militante de las filas demócratas ${ }^{184}$ que había sido elegido para integrar la fórmula con Harrison con miras a que la candidatura de este tuviera mayor equilibrio geográfico. Clay, antiguo amigo de Tyler y líder de los senadores whigs, creyó que podría dominarlo, pero no resultó así. Tyler vetó numerosas iniciativas legislativas de los whigs y estos, a su vez, rechazaron muchas de sus propuestas de designaciones, cuatro de ellas en el gabinete. Como resultado de esta controversia, los whigs nunca lograron tener, durante este período, una mayoría que les permitiera consolidar la supremacía legislativa a la que aspiraban.

\subsection{Los acuerdos legislativos sobre la distribución geográfica de la esclavitud}

Como parte de su preeminencia sobre el House, el Senado se convirtió en el principal foro de discusión de uno los problemas nacionales más importantes y sensibles de ese momento: la esclavitud. El debate, por cierto, tenía un trasfondo humanitario, pero su móvil también era económico y amenazaba seriamente con dividir a la Unión, como efectivamente ocurrió al final de este período. Mientras los estados del norte hacían grandes esfuerzos por abolirla, los del sur se resistían con dureza, pues ello comprometía seriamente sus economías rurales, basadas en gran medida en la mano de obra gratuita que la esclavitud representaba.

Si bien un primer paso importante en el intento por limitarla había tenido lugar en marzo de 1807 cuando, a instancias de Jefferson, el Congreso aprobó una ley que declaró ilegal -en todo el territorio de los Estados Unidos- el ingreso de esclavos a partir del 1 de enero de 1808, a lo largo de los años siguientes la esclavitud se convirtió en un problema que dividiría, geográfica y políticamente, al país a medida que este se expandía territorialmente. Ello ocurrió en dos oleadas: la primera tuvo lugar con la expansión al oeste del río Mississippi luego de la compra de Louisiana al Gobierno francés en 1803, y la segunda se produjo con la anexión de nuevos territorios luego de la guerra con México. Esta cuestión era particularmente sensible en el Senado, pues había estados con esclavitud y otros libres de ella, de modo que cada vez que se reconocía uno nuevo, se discutía cuál sería su condición ante dicho fenómeno.

183 Webster fue designado secretario de Estado y numerosos partidarios de Clay ocuparon cargos en el gabinete.

184 Antes de ello, Tyler había sido gobernador de Virginia (1825-1827) y senador nacional por ese estado (1827-1836). 
Todo ello generó, entre 1820 y 1854, tres acuerdos legislativos por medio de los cuales se dividió el territorio de los Estados Unidos entre estados sin esclavitud y estados con esclavitud. La línea divisoria fue el paralelo 36: los estados que estaban al norte eran libres y en los que estaban al sur se mantenía la esclavitud. El primer acuerdo fue celebrado en 1820, como consecuencia de la incorporación de Missouri como estado. Esto produjo el llamado Missouri Compromise, instrumentado en un conjunto de leyes que, además de resolver que Missouri sería un estado esclavista y Maine no, generó un acuerdo mediante el cual la incorporación de cada nuevo estado se llevaría a cabo alternando un estado esclavista con un estado libre como medio para mantener el equilibrio en el Senado.

Treinta años después, en 1850, con motivo de la anexión de los territorios obtenidos en la Mexican War de 1846-1848, fue necesario celebrar un nuevo acuerdo. Este conflicto le dio a los Estados Unidos la oportunidad de incorporar un vasto territorio ${ }^{185} \mathrm{y}$ correr su frontera hacia el oeste. ${ }^{186} \mathrm{Al}$ mismo tiempo, California, uno de los mejores frutos de la expansión, había crecido exponencialmente con el gold rush de 1849 y pretendía convertirse en estado. Surgió así el Compromise of 1850, integrado por cinco leyes que negociaron los senadores Henry Clay y Daniel Webster, por el Partido Whig, y Stephen Arnold Douglas, por los demócratas. Por medio de este conjunto de leyes: (a) se solucionó una disputa territorial de Texas; (b) se dispuso que los territorios de New Mexico, Nevada, Arizona y Utah serían organizados sin mención expresa de la esclavitud, cuestión que sería luego resuelta por sus habitantes al momento en que requirieran el otorgamiento de la condición de estado; (c) en el distrito de Columbia, donde existían los mayores mercados de esclavos, estos se eliminarían, sin perjuicio de la subsistencia de la esclavitud; y (d) California sería admitida como estado libre de esclavitud. ${ }^{187}$

185 Es el que actualmente ocupan los estados de Arizona, California, Colorado, New Mexico, Nevada, Utah y parte de Wyoming.

186 Sobre la guerra entre los Estados Unidos y México puede verse Meed (2002).

187 Adicionalmente, y como medio para pacificar a los políticos esclavistas que cuestionaron la incorporación de California como estado libre, rompiendo con ello el equilibrio logrado luego del Compromiso de Missouri de 1820, fue sancionada la Ley de Esclavos Fugitivos (Fugitive Slave Act), una norma brutal, plagada de disposiciones en las cuales el esclavo seguía siendo nada más que una mercancía despojada de todo derecho. Se les requería a todos los ciudadanos asistencia para la recuperación de los esclavos fugitivos, y si estos eran capturados, no podían testificar y carecían de todo derecho a un juicio por jurados. En sustitución eran sometidos a comisionados especiales, designados por los tribunales federales, que cobraban cinco dólares si ordenaban la libertad del esclavo y diez dólares si disponían su devolución al dueño original. Estas disposiciones montaron un 
Bajo estas cláusulas, el Compromiso de 1850 logró mantener unida a la Nación, pero fue una solución meramente temporaria que dividió más aún las aguas entre esclavistas y abolicionistas. Tan es así que cuatro años después, en 1854, una nueva embestida esclavista logró derogar el Compromiso de Missouri. El hecho tuvo lugar con motivo de la creación de los territorios de Kansas y Nebraska, en el marco de una nueva expansión hacia el oeste impulsada por varios factores, entre ellos, la construcción del llamado "ferrocarril transcontinental", que llegaría hasta la frontera oeste. Debía decidirse entonces la situación de la esclavitud en estos nuevos territorios ubicados al norte del paralelo 36. A tal fin se habían llevado a cabo, sin éxito, cuatro intentos de organizar un solo territorio, los que fueron boicoteados por los sureños que se oponían al Compromiso de Missouri. Finalmente, se impuso el proyecto del senador Stephen Douglas, presidente de la Comisión de Territorios, que hizo una fuerte concesión a los intereses esclavistas. Como resultado transaccional, fue sancionada la Ley Kansas-Nebraska (Kansas-Nebraska Act) de mayo de 1854, ${ }^{188}$ apoyada por el presidente Pierce, por medio de la cual se crearon dos territorios diferentes, disponiéndose que la población de cada uno en su momento decidiría la cuestión de la esclavitud. Era lo que Douglas llamó "el principio de la soberanía popular". Adicionalmente fue derogado el Compromiso de Missouri, bajo el cual la esclavitud habría sido prohibida en ambos territorios. Tal como veremos más adelante, la sanción de esta ley dio nacimiento al Partido Republicano.

\subsection{Las contiendas en el House por la designación del Speaker}

Una muestra de la fractura política del House, en dos mitades casi iguales a lo largo de este período, son las contiendas internas que se produjeron en 1839, 1849, 1855 y 1859 por la designación del Speaker, bien que estas ya se habían producido también con anterioridad, aunque con menor intensidad. ${ }^{189}$ Estas

reino de terror en la población negra, pues muchos de sus integrantes, aun sin ser esclavos, fueron secuestrados y sometidos como tales sin poder ejercer defensa alguna. Si bien es anterior a esta ley, la situación de los afroamericanos libres secuestrados y vendidos como esclavos fue relatada por Solomon Northup, una víctima de este crimen, en la célebre obra Twelve Years a Slave, publicada originalmente en 1853, que dio lugar a una también aclamada película en 2013.

18810 Statutes at Large 277.

189 Antecedentes de estas dificultades fueron las elecciones de 1819 y 1821 . En la primera debieron llevarse a cabo 22 votaciones para poder elegir a John Tyler, de New York, un candidato antiesclavista, sobre William Lowndes, de South Carolina. En la segunda, Philip P. Barbour, de Virginia, derrotó a Taylor luego de 12 votaciones. Estos datos, así como los de las siguientes contiendas electorales, fueron consultados en: https://history.house.gov/People/Office/Speakers-Multiple-Ballots/. 
contiendas tienen, como contexto general, el profundo debate sobre la esclavitud entre whigs y demócratas, pero se explican, además, por el equilibrio en número de representantes de ambos partidos y porque, en aquella época, el Speaker designaba a los miembros de las comisiones y a los presidentes de estas, lo que le otorgaba un gran poder.

En diciembre de 1839, al iniciarse el 26 Congreso (1839-1841), la distribución de las bancas en el House estaba prácticamente empatada entre los partidos. Había 120 representantes demócratas, 118 whigs y 5 bancas que todavía se disputaban. Luego de 4 días de agrias disputas, fue electo en forma temporaria John Quincy Adams. Luego, el 14 de diciembre, se decidió llevar a cabo la elección sin contar las bancas en disputa, y dos días después, luego de 11 votaciones, Robert M. T. Hunter, de Virginia, venció a John W. Jones, virginiano también.

Mucho más reñida fue la contienda de 1849 , producida al comienzo del $31^{\circ}$ Congreso (1849-1851), cuando la elección de Howell Cobb, un demócrata de Georgia, exigió 63 votaciones. Durante los años anteriores, merced al virtual empate en la distribución de las bancas entre demócratas y whigs, el control del House fue alternándose de un partido a otro con escaso margen de diferencia. Los whigs tuvieron el control del $27^{\circ}$ Congreso (1841-1843), los demócratas lo recuperaron en el 28० (1843-1845) y 29० (1845-1847) y los whigs lo retomaron nuevamente en el 30॰ (1847-1849). En 1848 fue electo presidente de los Estados Unidos Zachary Taylor, un militar con poca experiencia política, pero que había liderado la guerra con México y, como tal, era considerado un héroe nacional. Si bien Taylor había ganado con el apoyo del Partido Whig, estos no consiguieron controlar el House durante el 31 ${ }^{\circ}$ Congreso, que se reunió en diciembre de 1849. Ningún partido tenía la mayoría en ese momento, en el cual la cuestión más crítica a resolver era si en los nuevos territorios conquistados a México se impondría la esclavitud o si estos quedarían libres de ella. La elección del Speaker se hizo más difícil aún, pues ninguno de los dos partidos decidió apoyar a quienes eran los principales candidatos: Robert C. Winthrop, de Massachusetts, por los whigs, y Howell Cobb, por los demócratas. Como resultado de ello, 8 candidatos compitieron en la elección que fue decidida, luego de 63 votaciones, a favor de Cobb, el candidato demócrata y proesclavista, por un margen de apenas 2 votos.

Luego, en el $32^{\circ}$ y $33^{\circ}$ Congresos (1851-1855), tuvieron el control del House los demócratas proesclavistas, siendo Speaker Linn Boyd, de Kentucky. Pero en 1854, como reacción contra la Kansas-Nebraska Act ya mencionada, se formó 
el Partido Republicano, fuerte opositor a la esclavitud que, finalmente, sería el continuador de los whigs. Los republicanos participaron, por primera vez, en las elecciones en las que se eligieron representantes para el $34^{\circ}$ Congreso, reunido en diciembre de 1855, en el cual republicanos y whigs tuvieron una mayoría de 108 representantes, contra 83 demócratas. A pesar de esta mayoría, los opositores a la Kansas Nebraska Act no lograron unirse detrás de un solo candidato. Como resultado de ello, durante 2 meses se llevaron a cabo 133 votaciones, con 21 postulantes compitiendo en ellas. Finalmente, sin haber obtenido la mayoría, en febrero de 1856 Nathaniel P. Banks, de Massachusetts, fue declarado Speaker. No pertenecía a ninguna de los partidos mayoritarios, sino que militaba en una agrupación llamada American Party o Know Nothings, ${ }^{190}$ que luego se disolvió pasando a formar parte de las filas republicanas.

También fue muy disputada la elección de William Pennington, de New Jersey, en 1859. Como en el caso anterior, la decisión terminó recayendo, por compromiso, en un individuo casi desconocido que no tenía una clara afiliación política. Los demócratas controlaron el House durante el $35^{\circ}$ Congreso (1857-1859), pero al reunirse el 36 Congreso, en diciembre de 1859, ningún partido tenía el control de la Cámara, compuesta entonces por 109 republicanos, 101 demócratas y 27 know nothings. En un primer momento, parecía que la elección recaería en John Sherman, republicano de Ohio, ${ }^{191}$ quien llegó a tener 101 votos, pero la fuerte oposición ejercida por los demócratas contra aquel les hizo comprender a los republicanos que nunca resultaría electo. Sherman retiró entonces su candidatura y los republicanos le dieron su apoyo a Pennington, que obtuvo 117 votos en la $44^{\text {a }}$ votación. ${ }^{192}$

Como saldo institucional, estas contiendas no favorecieron la elección de figuras de relevancia. Ninguno de los 14 Speakers que sucedieron a Henry Clay entre 1825 y 1860 tuvieron su estatura e influencia, y solamente tres de ellos -Stevenson, Polk y Boyd- fueron elegidos como representantes en más de un Congreso.

190 Formada en la década de 1850, sus integrantes eran protestantes que se oponían a la ola de católicos llegados en esa época, principalmente desde Irlanda, sosteniendo que eran antidemocráticos. Las luchas entre protestantes y católicos de ese momento se hizo más conocida cuando, en 2002, fue llevada al cine en la película Gangs of New York (Pandillas de Nueva York), dirigida por Martin Scorsese.

191 Muchos años después, siendo senador, John Sherman fue el redactor de la Sherman Antritust Act (Ley Sherman Antimonopolios), sancionada en 1890 por el 51 Congreso (1889-1891).

192 De tal forma, Pennington fue electo Speaker en su primer y único mandato como representante. Murió poco después, en 1862. 


\subsection{Las discusiones sobre las peticiones relativas a la esclavitud}

No solo las elecciones de los Speakers fueron reñidas. La fractura interna del House entre los dos partidos mayoritarios se hizo sentir en muchos otros aspectos. Uno de ellos fue el tratamiento que la Cámara debía darle a las peticiones relativas a la esclavitud, aunque la división en este caso no fue tan tajante entre whigs y demócratas.

Desde 1792 existía la costumbre de no recibir este tipo de peticiones y propuestas, pero, en 1836, John Quincy Adams quebró esta práctica presentando una petición de ciudadanos de Massachusetts para abolir la esclavitud en el distrito de Columbia. A raíz de ello, se desató una fuerte disputa que terminó con la emisión de una resolución, aprobada por una mayoría de 117-68 votos, según la cual las propuestas relativas a la esclavitud serían recibidas por el House, pero no se les daría tratamiento. No contento con ello, al año siguiente, Adams insistió en presentar una nueva petición formulada por 22 esclavos. Su propuesta fue nuevamente rechazada por una mayoría de 163-18, con fundamento en que los esclavos carecían del derecho de petición otorgado por la Constitución a las personas libres. ${ }^{193}$ Tres años después, en 1840, se reanudó esta discusión y, por mayoría de 114-108, se decidió que el House no recibiría ni le daría tratamiento a ninguna petición en favor de abolir la esclavitud. No obstante, en 1844, esta regla fue derogada por una mayoría de 108-80 votos.

\subsection{Nuevas reglas de procedimiento para los debates en el House}

A medida que se iban desarrollando las actividades del House, se advirtió la necesidad de cambiar algunas reglas de procedimiento aplicables a los debates. Así, por ejemplo, en 1837 se dispuso que tendría precedencia en los debates el tratamiento de los proyectos de ley referidos a cuestiones financieras e impositivas. También se dispuso, en 1841, que las intervenciones de los representantes no podrían tener una duración de más de una hora. Esta medida ya había sido propuesta en 1820, cuando John Randolph habló durante más de 4 horas oponiéndose al Compromiso de Missouri.

Una cuestión que debía resolverse también era la prolongación indefinida de los debates en la Comisión de la Cámara en Pleno (Committee of the Whole). A tal fin, en 1841 se decidió que el House podía, por simple mayoría y sin debate previo, relevar a la Comisión del tratamiento del proyecto una

193 Hecht (1972, p. 545). 
vez que las enmiendas pendientes de aprobación hubieran sido rechazadas. No obstante, para evitar una terminación abrupta de la tarea de la Comisión del Pleno, en 1847 se decidió que los representantes que habían propuesto enmiendas al proyecto tendrían cinco minutos para explicarlas y defenderlas. Como ocurre habitualmente en la vida parlamentaria, esta regla dio lugar a una práctica que tendía a invalidarla, ya que los representantes de una minoría, con el fin de alargar indefinidamente el tratamiento de un proyecto al cual se oponían, proponían numerosas enmiendas que luego eran retiradas. Fue por ello que, en 1850 , se dispuso que el retiro de una enmienda debía hacerse por unanimidad.

Toda esta acumulación de reglas, que hacia 1858 sumaban más de 150, motivó que se designara una comisión especial (select committee) para revisarlas y ordenarlas. La tarea se completó en marzo de 1860 y tuvo un carácter técnico, sin que se llevaran a cabo cambios sustanciales en las reglas existentes.

\subsection{El sistema de comisiones}

Durante este período no se produjeron en el House grandes cambios en el sistema de comisiones. Básicamente, los cambios fueron cuantitativos, ya que a las comisiones permanentes (standing committees) existentes en 1825 se añadieron 8 más, llegando a sumar 34. La más importante -y más antigua- de todas ellas era y sigue siendo la de presupuesto y finanzas (Committee of Ways and Means). En el Senado, por el contrario, se produjeron cambios importantes en 1833 y 1846. En el primer caso, fue establecido que los miembros de las comisiones ya no serían designados por el vicepresidente, sino por votación de todos los senadores por medio de listas previamente acordadas. En el segundo caso, este poder de designación recayó aún más en los partidos políticos, ya que esas listas eran elaboradas por cada uno de ellos. Por lo general, en la elección de los miembros de cada comisión, y en particular en la presidencia de cada una de ellas, se tomaba la antigüedad como criterio. Si bien el sistema parecía correcto, se prestaba a algunos abusos, ya que, en 1859, todos los presidentes de comisiones pertenecían a estados esclavistas. ${ }^{194}$

194 Vid. Guide to Congress (2015, p. 113). 


\subsection{Nace el Partido Republicano}

Sin lugar a dudas, la Ley Kansas-Nebraska había sido una victoria esclavista al permitir que dos nuevos territorios ubicados al norte del paralelo 36 pudieran ser esclavistas. Ello quebraba claramente la regla establecida en el Compromiso de Missouri de 1820, pues, al dejar librada la cuestión de la esclavitud al voto popular, abría las puertas de esta en territorios que debían quedar libres de ella. Como reacción en contra de esta ley, comenzó a formarse, de forma espontánea y sin un liderazgo claramente identificado, una agrupación que muy rápidamente daría lugar al Partido Republicano. Tan fuerte y veloz fue esta gestación que, en 1860, Abraham Lincoln fue electo como el primer presidente republicano. Concomitantemente, en las elecciones para el $37^{\circ} \mathrm{Con}$ greso (1861-183), los republicanos obtuvieron una victoria aplastante contra los demócratas. ${ }^{195}$

A diferencia de los demócratas, que se alinearon detrás de Jackson luego de la elección de 1824, a la cual consideraban fraudulenta, los republicanos no tuvieron inicialmente un líder con el cual identificarse. Lincoln, que emergería como jefe indiscutido del partido en 1858, estaba por entonces lejos de serlo. ${ }^{196}$ Los orígenes del futuro Grand Old Party (GOP), como también se lo ha llamado desde $1885,{ }^{197}$ son dos reuniones que llevaron a cabo los opositores a la Ley Kansas-Nebraska en 1854. La primera de ellas se realizó el 28 de febrero en Ripon, Wisconsin; la segunda se llevó a cabo "bajo los robles" (under the oaks) el 6 de julio en Jackson, Michigan. ${ }^{198}$ Dos años después, se produjo la creación formal del partido. El 22 de febrero de 1856, en Pittsburgh, Pennsylvania, se llevó a cabo una reunión para preparar la primera convención nacional del partido, que tuvo lugar en Philadelphia el 17 de junio de ese año. En ella fue aprobada la primera plataforma partidaria. También surgió en forma espontánea el nombre del partido. Podría decirse que se debe a un editorial publicado por Horace Greeley en el New-York Tribune, en junio de 1854, en el que decía

195 En el Senado, los republicanos ganaron el doble de bancas que los demócratas: 31 a 15 (ver: https:// www.senate.gov/history/partydiv.htm), y en el House el triunfo fue aún mayor: obtuvieron 108 bancas contra solo 44 de los demócratas (ver: https://history.house.gov/Institution/Party-Divisions/ Party-Divisions/).

196 Hasta ese momento, Lincoln era un poco conocido abogado de Springfield, Illinois, que había sido representante por el Partido Whig en el $29^{\circ}$ Congreso (1847-1849), pero su figura creció indisputablemente luego de los célebres debates que mantuvo en 1858 con Stephen Douglas con motivo de la esclavitud. Ver Angle (1991).

197 Ver Gould (2003).

198 Como resultado de ello, ambas ciudades se disputan la maternidad del Partido Republicano. Para asegurarlo, en Jackson hay una placa, colocada "bajo los robles", que se la atribuye. 
que la denominación que unía a todos los opositores a la esclavitud era "republicanos" ${ }^{199}$

\subsection{La ampliación del Capitolio}

Vale la pena recordar aquí que, en 1851, el Congreso encaró un importante plan de ampliación de su edificio, dado que el constante crecimiento de sus legisladores había tornado incómodas las instalaciones existentes. El nuevo recinto del Senado fue completado en 1859 y este se mudó de la antigua chamber -que había sido empleada desde 1810 (Old Senate Chamber) - a la que ocupa actualmente. ${ }^{200} \mathrm{La}$ antigua sala del Senado fue asignada entonces a la Corte Suprema, que sesionó allí hasta la construcción de su propio edificio en $1935 .{ }^{201}$ Por su lado, el 16 de diciembre de 1857 se reunió el House por primera vez en su recinto actual en la apertura de las sesiones del 35 Congreso (1857-1859). Faltaba tan solo terminar algunos trabajos en el sistema de calefacción y en la escalera central de acceso. Con este nuevo recinto, mucho más amplio y que formaba parte de un plan de reformas en ambas alas del edificio comenzado en 1851, se reemplazaba el antiguo salón ${ }^{202}$ empleado desde 1819. La nueva cámara, más cómoda, lujosa y espaciosa que la anterior, necesaria para albergar al creciente número de representantes y con una mejor acústica, fue objeto sin embargo de algunas críticas. El senador Jacob Collamer, de Vermont, antiguo miembro del House en la década de 1840 , sostuvo que el nuevo recinto era demasiado suntuoso y colorido. ${ }^{203}$ También fue emplazada la nueva cúpula del edificio, diseñada por Thomas Ustick Walter, cuarto arquitecto del Capitolio. Fue construida entre 1855 y 1866 y su estructura no es de piedra, sino de hierro fundido.

199 "We should not care much whether those thus united (against slavery) were designated 'Whig,' 'Free Democrat' or something else; though we think some simple name like 'Republican' would more fitly designate those who had united to restore the Union to its true mission of champion and promulgator of Liberty rather than propagandist of slavery" (como se citó en Bueno de Mesquita-Smith, 2016, p. 217).

200 Ver: https://www.senate.gov/art-artifacts/publications/pdf/room-old-senate-chamber.pdf.

201 Hasta que fue construido su propio edificio, la Corte Suprema fue ocupando las salas que iba dejando vacante el Senado. Así ocurrió en 1810 y luego en 1860. Ver: https://www.senate.gov/ art-artifacts/publications/pdf/room-old-supreme-court-chamber.pdf.

202 Donde actualmente está ubicado el Statuary Hall.

203 Ver:https://history.house.gov/HistoricalHighlight/Detail/37069?current_search_qs=\%3FTerm\%3Dnumber\%2Bof\%2Brepresentatives\%26PreviousSearch\%3D\%26CurrentPage\%3D1\%26SortOrder\%3DDate. 


\section{La Guerra Civil y la Reconstrucción (1861-1877) 7.1. Las distorsiones políticas de este período}

De todos los períodos en los que puede ser dividido el proceso histórico del Congreso de los Estados Unidos, el que corre desde la secesión de los estados del sur en 1860 -que da origen a la Guerra Civil- hasta el final de la Reconstrucción en 1877, es sin dudas uno de los más críticos y el de mayor distorsión política. ${ }^{204}$ Sin mencionar los horrores propios de la guerra, en el terreno estrictamente legislativo basta recordar que las bancas de los estados del sur, tanto en el Senado como en el House, estuvieron vacantes, casi en su totalidad, desde 1861 hasta 1869, y que el Partido Demócrata en la Unión, durante esos años, fue una fuerza política minoritaria y debilitada. De hecho, muchos demócratas norteños emigraron hacia las filas republicanas. Como resultado de ello, los republicanos retuvieron la presidencia hasta 1885, cuando Grover Cleveland sucedió a Chester Arthur, ${ }^{205}$ y controlaron el House desde el 36 Congreso (1859-1861) hasta el 44 Congreso (1875-1877); y el Senado, desde el 37 Congreso (1861-1863) hasta el 45 Congreso (1877-1879).

La hegemonía republicana, sin embargo, no estuvo exenta de conflictos entre Lincoln y el Congreso. Uno y otro intentaron ejercer, durante el conflicto, una gran porción de poder. Muchas decisiones del Ejecutivo, tales como la suspensión del hábeas corpus, el llamado de voluntarios para combatir, el aumento de tropas y los gastos que ello demandaba, así como la liberación de esclavos en los estados rebeldes, fueron tomadas sin previo consentimiento del Congreso. Este, a su vez, creó la Comisión Conjunta sobre la Conducción de la Guerra (Joint Committee on the Conduct of the War), integrada por tres senadores y cuatro representantes, cuya misión, como su nombre lo indica, era controlar la marcha de la guerra. Asimismo, cuando en 1863 Lincoln emitió una proclamación sobre la futura reconstrucción de los estados del sur, estableciendo nuevos Gobiernos en Louisiana y Arkansas, el Congreso le respondió sancionado un proyecto de ley (Wade-Davis Bill) que transfería esa tarea a la órbita legislativa. Lincoln, entonces, ejerció el pocket veto (veto de bolsillo) sobre la ley, lo que dio

204 En el Anexo VI (p. 439) menciono brevemente los hechos que dieron lugar al conflicto.

205 Durante 25 años, desde Lincoln (1861-1865) hasta Chester Arthur (1881-1885), la presidencia estuvo bajo el control de los republicanos. De todos modos, hay que hacer la salvedad de que Andrew Johnson, vicepresidente de Lincoln en la segunda presidencia y sucesor de este luego de su asesinato, era demócrata. Para la elección de 1864, Lincoln y Johnson habían formado una lista de coalición llamada National Union Party. No obstante, el control político del país lo tenían en ese momento los republicanos, que estuvieron a punto de destituir a Johnson en el Juicio Político de 1868. 
lugar, a su vez, al Wade-Davis Manifesto, un documento en el cual el Congreso se expresó en duros términos, reafirmado su autoridad en la materia y sosteniendo que el presidente debía limitarse a ejercer su función ejecutiva. ${ }^{206}$

\subsection{El Joint Committee on the Conduct of the War}

En los comienzos de la guerra, los norteños sufrieron varias derrotas inesperadas. La primera ocurrió en Bull Run Creek, en julio de 1861, conocida como la Batalla del Picnic (Picnic Battle) por sus tragicómicas características. ${ }^{207} \mathrm{~A}$ ella le siguieron otros reveses para los ejércitos de la Unión, tales como el de Ball's Bluff, en octubre de ese mismo año, en el que murió el senador Edward D. Baker, un amigo muy cercano de Lincoln. A raíz de ello, en el Congreso se levantaron voces en demanda de una investigación de estos reveses militares, que fueron respondidas inicialmente por el senador Zachariah T. Chandler, de Michigan, quien propició, en diciembre de 1861, la sanción de una resolución para investigar las derrotas de Bull Run y Ball's Bluff. Esta iniciativa, sin embargo, no fue considerada suficiente por quienes pretendían llevar a cabo una investigación aún más amplia. Fue así que el senador James W. Grimes, de Iowa, proyectó una resolución, aprobada el 10 de diciembre de 1861, mediante la cual fue creado la Joint Committee on the Conduct of the War, una comisión conjunta integrada por tres senadores y cuatro diputados, a la que se le otorgaron amplios poderes para "investigar la conducción de la presente guerra y ordenar la producción prueba testimonial y documental”. 208

Aunque sus propósitos eran correctos, estando dominada por republicanos

206 Entre otras consideraciones, el manifiesto dice: "The authority of Congress is paramount and must be respected; that the whole body of the Union men of Congress will not submit to be impeached by him of rash and unconstitutional legislation; and if he wishes our support, he must confine himself to his executive duties-to obey and execute, not make the laws-to suppress by arms armed Rebellion, and leave political reorganization to Congress".

207 En la mañana del domingo 21 de julio de 1861, legisladores, abogados, periodistas y otras personas de Washington se congregaron en Centreville, Virginia, para ver cómo combatían los ejércitos del norte y del sur. Ubicados en una colina sobre Bull Run Creek, habían llevado sándwiches y bebidas con el mismo espíritu que anima a quien se dispone a ver un espectáculo deportivo. Después de un buen comienzo para los norteños, la situación se tornó en su contra y, hacia las 16 horas, las tropas de la Unión comenzaron a desbandarse en una retirada apresurada y desordenada, atropellando a los civiles que había ido a observar la batalla. El senador Henry Wilson, de Massachusetts, tuvo que huir montado en una mula luego de que el carrito desde el cual repartía los sándwiches fuera destruido por un disparo de cañón. Ver: https://www.senate.gov/about/powers-procedures/investigations/joint-committee-conduct-of-war.htm.

208 "Inquire into the conduct of the present war and to send for persons and papers". 
radicales, la Comisión se tornó rápidamente en un órgano político enfrentado, en ocasiones, con el propio Lincoln, a quien acusaban de ser muy tolerante con el bando contrario y cuestionaban su estrategia en la conducción del conflicto, pese a que sus miembros no tenían experiencia militar alguna. Habían decidido, incluso, que sus deliberaciones serían secretas, pero varios de sus integrantes violaron esta regla pasando información a la prensa con la expectativa de que su tarea fuera apoyada por el público. Sin perjuicio de ello, la Comisión llevó a cabo una intensa tarea de escrutinio sobre la marcha de la Guerra, no solo en el plano de las operaciones militares, sino también en relación con el tratamiento de los prisioneros y de la corrupción en los contratos de provisión de armamentos y otros elementos. Sus tareas se desarrollaron durante los Congresos $37^{\circ}$ y $38^{\circ}$ a lo largo de los cuatros años que duró el conflicto (18611865). La Comisión se reunió en 272 oportunidades y recopiló gran cantidad de documentos y testimonios, algunos de ellos tomados en el lugar mismo de los hechos. Todo este material fue recopilado en cuatro informes anuales, publicados en 1863, 1864, 1865 y 1866.

\subsection{Los republicanos radicales y sus conflictos con Andrew Johnson}

Como ocurre habitualmente, en el joven Partido Republicano de aquel entonces anidaban varias tendencias. Los halcones, en este caso, eran los republicanos radicales, abolicionistas estrictos que no tardaron en lanzarse contra el vicepresidente Andrew Johnson cuando Lincoln fue asesinado en 1865. Nacido y criado en el sur, ${ }^{209}$ Johnson carecía de toda formación intelectual, ${ }^{210}$ aunque tenía bastante experiencia política. ${ }^{211}$ Sus talentos, sin embargo, eran muy escasos para manejar la difícil situación que le tocó vivir, agravado todo ello por su muy mala relación con el Congreso, dominado por los republicanos. Tanto era el encono en su contra que, a fin de evitar que pudiera cubrir las vacantes en la Corte Suprema con jueces que se opusieran a la Reconstrucción, fue reducido el número de los integrantes del Tribunal, el cual fue aumentado nuevamente en 1869 cuando Ulysses S. Grant ocupó la presidencia. ${ }^{212}$

209 Había nacido en North Carolina y desarrolló su vida política en Tennessee.

210 Jamás fue a la escuela y había trabajado como sastre antes de entrar a la política.

211 Fue gobernador de Tennessee en 1853-1857; luego, senador por dicho estado en 1857-1862; y durante la Guerra Lincoln lo designó gobernador militar también allí.

212 En 1865, la Corte tenía 10 jueces, como resultado de una ampliación producida en 1863. Johnson tuvo una primera oportunidad para nombrar un juez en la Corte con la vacante producida al morir 
Sin embargo, el pico de la colisión entre Johnson y el Congreso tuvo lugar en 1868, cuando se lo intentó destituir por juicio político. El detonante de este juicio fue la controversia suscitada en torno a la destitución de Edwin W. Stanton como secretario de Guerra, acto que, a juicio de los opositores de Johnson, violaba la ley que regulaba los nombramientos de los funcionarios ejecutivos (Tenure of Office Act). Stanton, que había sido designado por Lincoln, se oponía a la política de Johnson sobre la Reconstrucción y fue removido de su cargo, en agosto de 1867, durante el receso del Congreso, siendo reemplazado por Ulysses S. Grant, designado en forma interina. Al reunirse nuevamente el Senado, durante el otoño de ese año, repuso a Stanton en su cargo y Johnson lo destituyó nuevamente, designando al general Lorenzo Thomas como su reemplazo. Como respuesta, la Comisión Conjunta sobre la Reconstrucción (Joint Committee on Reconstruction), a la que me referiré en el punto siguiente, elaboró una resolución en la cual se promovió el juicio político contra Johnson, imputándole once cargos. Esta resolución fue aprobada en el House por una mayoría de 126-47 votos. En el Senado, el juicio comenzó en marzo de 1868 bajo la presidencia del Chief Justice Salmon P. Chase. Era la primera vez en la historia de los Estados Unidos que se promovía un juicio político contra un presidente y el caso, como era inevitable, atrajo toda la atención de la prensa y del público. Finalmente, dos meses después -en mayo de 1868-, el Senado emitió su veredicto, en el cual faltó un solo voto para alcanzar los dos tercios necesarios para obtener una sentencia de condena. Una mayoría de 35 senadores votó por la destitución y 19 -entre ellos siete republicanos- votaron por la absolución. ${ }^{213}$

John Catron, en 1865. Después de vacilar durante un año, eligió finalmente a Henry Stanbery, su Attorney General (ministro de Justicia) y respetado abogado. Pero la relación entre el Congreso y el presidente por aquel entonces era tan mala que, como dice Henry Abraham, ni Dios hubiera obtenido el acuerdo de haber sido nominado por Johnson. Se temía que Johnson designara jueces contrarios a la legislación de la Reconstrucción, protectora de los derechos de los esclavos recientemente liberados. De hecho, Johnson había vetado algunas de estas leyes No solo se rechazó la propuesta de Johnson, sino que el Congreso fue más lejos aún. Para evitar que se produjeran nuevas nominaciones, se redujo el número de jueces de diez a nueve y, además, se estableció que, de producirse una nueva vacante, el número de jueces se reduciría a ocho. Así, cuando en 1867 falleció el juez James Wayne, su sillón también fue eliminado. Terminada la presidencia de Johnson, su sucesor fue Ulysses S. Grant, héroe de la Guerra Civil. Con Grant en la presidencia y aventados los peligros que su predecesor representaba para la Reconstrucción, el Congreso, en 1869, elevó nuevamente a 9 los jueces de la Corte, número que se ha mantenido desde entonces. Vid. Abraham (1985, pp. 123-124).

213 Ver Wineapple (2020). 


\subsection{El liderazgo en el House}

A diferencia de lo que se verá en el período siguiente, con el fuerte liderazgo de Thomas B. Reed y Joseph G. Cannon, los Speakers en este período no fueron auténticos líderes del House. Schuyler Colfax, de Indiana, ocupó el cargo entre 1863 y 1869 y lo dejó para ser vicepresidente de Ulysses Grant durante su primer período. Calificado como un figurehead (figura decorativa), Colfax tuvo su momento más decisivo cuando ejerció el casting vote para desempatar la votación de lo que sería la Enmienda XIII de abolición de la esclavitud, quebrando con ello la costumbre de que el Speaker no ejercía tal poder. Sin embargo, el verdadero líder del House en esos años fue Thaddeus Stevens, de Pennsylvania, un republicano radical que había liderado el juicio político contra Johnson. Como presidente de la Comisión de Presupuesto (Ways and Means Committe) y de la Comisión de Ingresos Fiscales (Appropriations Committee), creada en 1865, Stevens era el verdadero conductor del House, función que ejercía -según algunos- en forma tiránica. ${ }^{214}$ Colfax fue sucedido en 1869 por James G. Blaine, de Maine, también republicano, quien presidió el House hasta 1875. Con mayor autoridad que su predecesor, Blaine manejó los nombramientos en las comisiones para lograr la sanción de las leyes que le interesaban. ${ }^{215}$

\subsection{El Joint Committee on Reconstruction y la legislación derivada de la Guerra Civil}

Terminada la Guerra Civil, comenzó la llamada Reconstrucción de los estados del sur, que tuvo importantes consecuencias en el orden constitucional y legislativo. Para analizar el problema de los estados vencidos y su organización, el 39 Congreso (1865-1867) estableció, el 13 de diciembre de 1865, la llamada Comisión Conjunta para la Reconstrucción (Joint Committee on Reconstruction), con el objeto de investigar e informar sobre la situación existente en los exestados confederados y proponer la legislación necesaria para reorganizarlos. Presidido por el senador William Pitt Fessenden, de Maine, un republicano moderado, la comisión se integró con quince miembros: seis senadores y nueve representantes. Todos ellos, salvo tres, eran republicanos. Entre los republicanos radicales se encontraba Thaddeus Stevens, representante de Pennsylvania,

214 Ver MacNeil (2011, p. 185).

215 Dentro de su partido, Blaine compitió sin éxito en dos oportunidades para la nominación como presidente de la República. Perdió en 1876 con Hayes y en 1880 con Garfield. Fue nominado, finalmente, en 1884, pero perdió la elección con Cleveland, con quien los demócratas retornaron a la Casa Blanca luego de largos años fuera de ella. 
y entre los republicanos moderados se destacó John A. Bingham, representante de Ohio, quien colaboró en la propuesta de las enmiendas constitucionales para proteger los derechos civiles, a las que me referiré enseguida. ${ }^{216}$ Entre febrero y mayo de 1866, cuatro subcomisiones reunieron pruebas y tomaron numerosos testimonios sobre la situación existente en el sur, entre ellos, al general Robert E. Lee y a Alexander H. Stephens, exvicepresidente de los estados confederados. Mientras los testimonios de los confederados afirmaban que en el sur la situación era pacífica y se estaba en condiciones de retornar a la normalidad, los testimonios de los norteños daban cuenta de una situación de fuerte violencia racial contra los negros y quienes los apoyaban. Como conclusión de su tarea, la comisión conjunta elaboró un informe -en el cual no constan los debates internos- que dio lugar a la legislación sobre la Reconstrucción, a la que me referiré seguidamente. ${ }^{217}$

En el terreno legislativo, se incorporaron a la Constitución las Enmiendas XIII, XIV y XV, ratificadas entre 1865 y 1870. Juntamente con ellas, el Congreso sancionó la Civil Rights Act of 1866 (Ley de Derechos Civiles) ${ }^{218}$ y las llamadas Reconstructions Acts of 1867 (Leyes de la Reconstrucción), un grupo de cuatro leyes sancionadas entre marzo de 1867 y marzo de 1868, que establecieron el Gobierno militar en los estados del sur con la intención de organizarlos y reintegrarlos a la Unión. ${ }^{219}$ Esta nueva legislación provocó fuertes resistencias, que acentuaron las diferencias ya existentes entre los estados beligerantes. Los sureños, aun vencidos y destrozados económicamente, ejercieron una fuerte oposición a la nueva legislación. Básicamente, se oponían a igualarse jurídicamente con sus otrora esclavos.

La primera Enmienda constitucional surgida después de la Guerra Civil eliminó la esclavitud. Era evidente que si esta había sido la causa principal del conflicto, su abolición figuraría entre las primeras medidas posteriores al cese del fuego. Ya con anterioridad a la rendición final de las fuerzas del sur,

216 Además de Stevens y Bingham, los otros representantes que integraron la comisión fueron: Elihu Washburne (republicano de Illinois), Justin Morrill (republicano de Vermont), Roscoe Conkling (republicano de New York), George Boutwell (republicano de Massachusetts), Henry T. Blow (republicano de Missouri), Henry Grider (demócrata de Kentucky) y Andrew Jackson Rogers (demócrata de New Jersey). Además de Fessenden, los otros senadores fueron: James W. Grimes (republicano de Iowa), Jacob Howard (republicano de Michigan), George Henry Williams (republicano de Oregon), Ira Harris (republicano de New York) y Reverdy Johnson (demócrata de Maryland).

217 Ver Kendrick (1969).

21814 Statutes at Large 27-30.

21914 Statutes at Large 428-430 (2 de marzo de 1867); 15 Statutes at Large 2-5 (23 de marzo de 1867); 15 Statutes at Large 14-16 (19 de julio de 1867); 15 Statutes at Large 41 (11 de marzo de 1868). 
la Enmienda había sido propuesta en el Congreso el 31 de enero de 1865. Por medio de ella, se declaró formalmente abolida la esclavitud, salvo la que fuera impuesta como pena por delitos debidamente juzgados. Luego de enunciado este principio, se le otorgaron al Congreso facultades para ponerlo en práctica por medio de legislación adecuada. ${ }^{220}$

Inmediatamente después de la Enmienda XIII, el Congreso sancionó -pese al veto del presidente Johnson- ${ }^{221}$ la Civil Rights Act of 1866, la primera de las ocho leyes de derechos civiles que ha tenido los Estados Unidos. ${ }^{222}$ Con ella se intentaba contrarrestar los llamados Black Codes (Código Negros) que habían empezado a sancionarse en los estados del sur, por medio de los cuales se privaba a los negros de los derechos de votar, de dar testimonio en juicio, de casarse con blancos, etc. Desde su primera sección, la ley marcaba los efectos de la Guerra Civil al reconocer una igualdad completa entre blancos y negros y extenderles la ciudadanía a estos últimos. ${ }^{223}$ Para reforzar este principio, se imponían penas de prisión y de multa a quienes ejercitaran actos contrarios a

220 Dice esta Enmienda: "1. Ni en los Estados Unidos ni en ningún lugar sujeto a su jurisdicción habrá esclavitud ni trabajo forzado, excepto como castigo de un delito del que el responsable haya quedado debidamente convicto. 2. El Congreso estará facultado para hacer cumplir este artículo por medio de leyes apropiadas" ("Section 1. Neither slavery nor involuntary servitude, except as a punishment for crime whereof the party shall have been duly convicted, shall exist within the United States, or any place subject to their jurisdiction. Section 2. Congress shall have power to enforce this article by appropriate legislation").

Su antecedente inmediato fue la Proclama de Emancipación (Emancipation Proclamation), ordenada por Abraham Lincoln en 1863. En plena guerra, invocando sus poderes de guerra, el presidente proclamó la emancipación de todos los esclavos existentes en los estados del sur que se hallaban en conflicto. De todos modos, y para evitar cualquier planteo de nulidad de esta Proclama, el Congreso creyó necesario darle rango constitucional a la abolición. Desde su propuesta a los estados hasta que se obtuvieron las ratificaciones necesarias para su entrada en vigencia transcurrió menos de un año. El 6 de diciembre de 1865 se obtuvo el voto de Georgia necesario para ello y el 18 de diciembre fue certificada formalmente por el secretario de Estado. Pero la reticencia de algunos de los estados del sur para dar su aprobación fue tal que Kentucky recién la ratificó más de un siglo después -en 1976- y Mississippi lo hizo en 1995, después de haberla rechazado ambos inicialmente.

221 Johnson llegó a ejercer el veto sobre las leyes de la Reconstrucción en 29 ocasiones, 15 de las cuales fueron rechazadas por el Congreso.

222 Le sucederían luego las de 1871 (17 Statutes at Large 13), 1875 (18 Statutes at Large 335), 1957 (71 Statutes at Large 634), 1960 (74 Statutes at Large 86), 1964 (78 Statutes at Large 241), 1968 (82 Statutes at Large 73) y 1991 (Public Law 102-166; § 109, 42 U.S.C. § 2000e et seq).

223 Decía esta Sección 1: "Be it enacted, That all persons born in the United States and not subject to any foreign power, excluding Indians not taxed, are hereby declared to be citizens of the United States; and such citizens, of every race and color, without regard to any previous condition of slavery or involuntary servitude, except as a punishment for a crime whereof the party shall have been duly convicted, shall have the same right, in every State and Territory in the United States, to make and enforce contracts, to sue, be parties, and give evidence, to inherit, purchase, lease, sell, hold, and convey real and personal property, and to full and equal benefit of the laws and proceedings for the 
los derechos reconocidos en la ley. ${ }^{224}$ Aun así, la lucha por imponer la igualdad completa entre blancos y negros no fue fácil y la Corte demoraría más de setenta años en admitirla plenamente. ${ }^{225}$

Sin perder tiempo, pocos meses después -en junio de 1866-, el Congreso propuso la Enmienda XIV, la que luego de un largo proceso de ratificación entró en vigencia en julio de 1868, luego de ser aprobada por 28 de los 37 estados entonces existentes. ${ }^{226}$ El propósito de esta Enmienda era erradicar toda duda que pudiera presentarse acerca de los derechos reconocidos por la Ley de Derechos Civiles. ${ }^{227}$ De las tres Enmiendas de la Reconstrucción, sin dudas esta es la que mayor aplicación judicial ha suscitado debido a las cláusulas del debi-

security of person and property, as is enjoyed by white citizens, and shall be subject to like punishment, pains, and penalties, and to none other, any law, statute, ordinance, regulation, or custom, to the contrary notwithstanding".

224 "Section. 2. And be it further enacted, That any person who, under color of any law, statute, ordinance, regulation, or custom, shall subject, or cause to be subjected, any inhabitant of any State or Territory to the deprivation of any right secured or protected by this act, or to different punishment, pains, or penalties on account of such person having at any time been held in a condition of slavery or involuntary servitude, except as a punishment for any crime whereof the party shall have been duly convicted, or by reason of his color or race, than is prescribed for the punishment of white persons, shall be deemed guilty of a misdemeanor, and, on conviction, shall be punished by fine not exceeding one thousand dollars, or imprisonment not exceeding one year, or both, in the discretion of the court".

225 Lo hizo recién en la década 1950, cuando resolvió los casos de segregación racial, en particular Brown v. Board of Education of Topeka, 347 U.S. 483 (1954).

226 La ratificación de la Enmienda XIV fue un proceso largo y complicado. Cuando se admitió a Nebraska en calidad de trigésimo séptimo estado, el 1 de marzo de 1867, el requisito de ratificación por las tres cuartas partes de los estados impuso la necesidad de que votaran por ella un total de veintiocho. En 1866 hubo seis ratificaciones y otros dieciséis estados ratificaron la enmienda en 1867. Iowa lo hizo en abril de 1868. Antes de aquella fecha, los exestados confederados ya habían advertido que, sometidos a las Leyes de Reconstrucción, tenían que ratificar dicha enmienda u obedecer a los Gobiernos militares instalados luego de la Guerra Civil. En abril de 1868 se decidió Arkansas; en junio ratificó Florida; en julio, Carolina del Norte, Louisiana, Carolina del Sur y, por fin, Alabama, el estado vigésimo noveno. Sin embargo, Ohio, en enero de 1868, y Nueva Jersey, en abril, habían manifestado su intención de retirar su respectiva ratificación. El 20 de julio, el secretario de Estado Seward dio una proclama condicional: la enmienda estaría en vigor si el retiro de Ohio y de Nueva Jersey quedaba sin efecto. El 21 de julio, el gobernador electo por Georgia telegrafió al presidente de la Cámara de Representantes que aquel estado acababa de ratificar la enmienda. Se tenían, pues, veintiocho estados, aun sin contar a Ohio y Nueva Jersey. Tras un breve debate acerca de la autenticidad del aviso telegráfico, la Cámara declaró ratificada la enmienda. El Senado había hecho lo mismo sin esperar a Georgia. El secretario de Estado promulgó entonces la enmienda incondicionalmente el 28 de julio de 1868. Oregon dio a entender su intención de retirar la ratificación en octubre de 1868, pero Virginia la ratificó en 1869 y Mississippi y Texas en 1870. La Enmienda XIV tenía, pues, a su favor tres cuartas partes de los estados.

227 Es por ello que su primera sección establece: "Todas las personas nacidas o naturalizadas en los Estados Unidos y sometidas a su jurisdicción son ciudadanos de los Estados Unidos y de los Estados 
do proceso y de la igualdad. ${ }^{228}$ La segunda sección regula y tutela los derechos electorales, la tercera limita los derechos políticos de quienes hayan incurrido en actos de rebelión contra los Estados Unidos, la cuarta se ocupa de la deuda pública y rechaza toda aquella que pudiera haberse generado como consecuencia de la liberación de esclavos y la quinta, por último, le reconoce al Congreso facultades suficientes para hacer cumplir lo establecido en la enmienda.

Aunque estaban devastados, los estados del sur se resistían férreamente a reconocer la autoridad que sobre ellos pretendían ejercer las autoridades nacionales. Se negaron a ratificar la Enmienda XIV y no acataban la Ley de Derechos Civiles. ${ }^{229}$ Para poner coto a esta situación, el Congreso sancionó las Leyes de la Reconstrucción, que establecieron - provisionalmente y hasta tanto pudiera reorganizarse debidamente la autoridad civil- Gobiernos militares en los estados de Virginia, North Carolina, South Carolina, Georgia, Mississippi, Alabama, Louisiana, Florida, Texas y Arkansas ${ }^{230}$ como medio de evitar el pillaje y el desorden propios de la anarquía. Se crearon entonces cinco distritos militares bajo la autoridad directa del Gobierno federal. ${ }^{231} \mathrm{Al}$ mando de cada uno de estos distritos se puso a un oficial de alto rango, dotado de autoridad administrativa y judicial, bien que no podía aplicar castigos crueles e inusuales.

No obstante todo ello, la resistencia en el sur a reconocer los derechos de los

en que residen. Ningún Estado podrá dictar ni dar efecto a cualquier ley que limite los privilegios o inmunidades de los ciudadanos de los Estados Unidos; tampoco podrá Estado alguno privar a cualquier persona de la vida, la libertad o la propiedad sin el debido proceso legal; ni negar a cualquier persona que se encuentre dentro de sus límites jurisdiccionales la protección de las leyes, igual para todos" ("All persons born or naturalized in the United States, and subject to the jurisdiction thereof, are citizens of the United States and of the state wherein they reside. No state shall make or enforce any law which shall abridge the privileges or immunities of citizens of the United States; nor shall any state deprive any person of life, liberty, or property, without due process of law; nor deny to any person within its jurisdiction the equal protection of the laws").

228 La primera de ellas, incluso, ha sido una de las principales claves en manos de la Corte para regular la constitucionalidad de las leyes estatales, bien que esa facultad ya había sido ejercida con anterioridad desde United States v. Peters, 9 U.S. 115 (1809) y Fletcher v. Peck, 10 U.S. 87 (1810). El primer caso en el que la constitucionalidad de una ley estatal fue escrutada bajo la Enmienda XIV fue el de los mataderos de Louisiana en 1873, Slaughterhouse Cases, 83 U.S. 36 (1873).

229 Incluso, en la mayoría de los estados vencidos comenzaron a organizarse asociaciones clandestinas que proclamaban la supremacía de la raza blanca. El más célebre de todos ellos ha sido el Ku Klux Klan, fundado en 1866 en la ciudad de Pulaski, Tennessee, que tomó su nombre de la palabra griega kuclos, que significa "círculo".

230 Curiosamente, Tennessee -la patria del Ku Klux Klan- no fue incluido en la ley, pues había ratificado la Enmienda XIV.

231 Virginia constituía el primer distrito; North Carolina y South Carolina, el segundo; Georgia, Alabama y Florida, el tercero; Mississippi y Arkansas, el cuarto; y finalmente Louisiana y Texas, el quinto. 
negros era tal que fue necesario incorporar una tercera enmienda constitucional, la Enmienda XV, por medio de la cual se reconocen en absoluta condición de igualdad para todos los ciudadanos los derechos electorales. ${ }^{232}$ Esta tercera Enmienda de la Reconstrucción parece redundante ante el texto de las dos anteriores, pero es evidente que en su época no lo fue. Fue propuesta por el Congreso en febrero de 1869 y obtuvo su ratificación un año después.

\subsection{Los primeros legisladores afroamericanos}

Como resultado de las reformas legislativas antes mencionadas, comenzaron a ingresar al Congreso los primeros legisladores afroamericanos. Ellos fueron: los senadores republicanos por Mississippi Hiram Revels, elegido en 1870, y Blanche K. Bruce, elegido en 1874. Entre los primeros representantes cabe mencionar a Joseph Rainey (South Carolina, 1870), Robert C. De Large y Robert B. Elliott (South Carolina, 1871), Josiah T. Walls (Florida, 1871), Jefferson F. Long (Georgia, 1871) y Benjamin S. Turner (Alabama, 1873). Es difícil imaginar actualmente la revolución que este hecho produjo en su momento, ya que escasos diez años antes esas mismas bancas estaban ocupadas por propietarios de esclavos. Desde entonces, un total de 173 afroamericanos han sido elegidos como senadores o representantes en el Congreso.

Aun así, esta corriente se vio rápidamente interrumpida a raíz de la finalización de la Reconstrucción, producida con el Compromiso de 1870 (al que me referiré más abajo), por medio del cual las tropas federales dejaron de ocupar los estados del sur, dejando a los afroamericanos librados a su suerte en manos de sus antiguos propietarios. Como consecuencia de ello, hacia 1890, la mayoría de aquellos ya habían sido excluidos de toda participación política. El último legislador negro de esa época fue George White, representante de North Carolina, que dejó su banca en marzo de 1901. Desde entonces, y por espacio de casi tres décadas, ningún otro afroamericano pudo ser legislador. ${ }^{233}$ Recién en 1928, Oscar De Priest fue electo como representante republicano

232 "Ni los Estados Unidos, ni ningún otro Estado, podrán desconocer ni menoscabar el derecho de sufragio de los ciudadanos de los Estados Unidos por motivo de raza, color o de su condición anterior de esclavos" ("The right of citizens of the United States to vote shall not be denied or abridged by the United States or by any State on account of race, color, or previous condition of servitude").

233 También se les vedó a los afroamericanos el derecho al voto. A tal fin, muchos estados crearon, como condición para conceder el franchise (derecho a registrarse como elector), los test de capacitación (literacy test), consistentes en rendir un examen de lectura y comprensión de la constitución local y las llamadas Grandfather Clause (Cláusula Abuelo), por medio de las cuales se eximía de rendir el 
por Illinois, llegando a ocupar su banca en tres períodos consecutivos (1929$1931,1931-1933$ y $1933-1935) .{ }^{234}$

\subsection{La ley de $\mathbf{1 8 6 6}$ sobre la elección de los senadores}

Hasta 1866, la elección de los senadores estaba regulada por las respectivas disposiciones de cada estado. De acuerdo con el artículo I, sección 3, el Senado se integraba con dos senadores por cada estado elegidos por la legislatura local por un término de seis años. Cuando la Constitución fue sancionada, se suponía que este sistema de elección indirecta promovería una mejor relación entre el Gobierno federal y los estados. Así lo explica Madison en el capítulo 62 de El Federalista. ${ }^{235}$ Jay, por su lado, en el capítulo 64 -no exento de ingenuidad-, afirmaba que con el método propuesto se elegiría a los hombres más probos y capaces. ${ }^{236}$ Pese a estas loables creencias, con el correr del tiempo quedó demostrado que el sistema favorecía la manipulación política de la elección, lo que fue suscitando crecientes protestas en procura de la elección directa de los senadores. Muchas bancas eran literalmente compradas por grupos de influencia, que llenaban los cargos con individuos ligados a sus intereses, poco estimulados para proteger los derechos de quienes no habían colaborado o contribuido en su elección. Además de ello, el sistema era inconveniente, pues ya sea que las legislaturas locales votaran separada o conjuntamente, conforme lo establecido

literacy test a los descendientes de quienes ya hubieran tenido derecho a votar con anterioridad al mes de enero de 1866. Naturalmente, esta fecha estaba cuidadosamente elegida, pues solo beneficiaba a los blancos, de manera tal que muchos de ellos quedaban exentos de rendir un examen que, tal vez, no hubieran aprobado. Una de estas cláusulas figuraba en la Constitución de Oklahoma, conforme una enmienda sancionada en 1910 y fue declarada inconstitucional en Guinn v. United States, 238 U.S. 347 (1915) por ser violatoria de la Enmienda XV. Por el contrario, los literacy test fueron declarados constitucionales en Lassiter v. Northampton County Board of Education, 360 U.S. 45 (1959).

234 Ver Swain (1993).

235 "Among the various modes which might have been devised for constituting this branch of the government, that which has been proposed by the convention is probably the most congenial with the public opinion. It is recommended by the double advantage of favouring a select appointment, and of giving to the state governments such an agency in the formation of the federal government, as must secure the authority of the former, and may form a convenient link between the two systems" (Carey y McLean, 2001, p. 320).

236 "As the select assemblies for choosing the president, as well as the state legislatures who appoint the senators, will, in general, be composed of the most enlightened and respectable citizens, there is reason to presume, that their attention and their votes will be directed to those men only who have become the most distinguished by their abilities and virtue, and in whom the people perceive just grounds for confidence" (Carey y McLean, 2001, p. 333). 
en las respectivas leyes estatales, la elección muchas veces quedaba trabada.

En vista de todo ello, en 1866 el Congreso decidió regular la elección de los senadores por medio de una legislación federal uniforme. Fue sancionada a este fin la Election Law of $1866,{ }^{237}$ mediante la cual se dispuso que la elección debía tener lugar el segundo martes del mes en cada cámara legislativa, por separado, donde sus miembros votaban en voz alta. Al día siguiente, las cámaras debían reunirse conjuntamente para verificar el resultado y, en caso de que la elección no hubiera recaído sobre el mismo candidato, debían reunirse todos los días sucesivos hasta elegir al senador. Esta ley estuvo vigente por espacio de casi medio siglo, hasta 1912, cuando fue sancionada la Enmienda XVII. No obstante, sus resultados fueron magros, tal como señaló en su momento Haynes (1938) en su clásica obra sobre el Senado de los Estados Unidos. ${ }^{238}$ Las elecciones con frecuencia eran obstaculizadas o paralizadas hasta que los grupos de interés lograban imponer a sus candidatos, todo lo cual distorsionaba el proceso electoral y comprometía la labor legislativa. ${ }^{239}$

\subsection{La elección presidencial de 1876, el Compromiso de 1877 y el fin de la Reconstrucción}

En 1876, al concluir el segundo mandato de Ulysses S. Grant, se produjo una contienda electoral que puso en jaque al sistema. Compitieron por la presidencia Rutherford B. Hayes, por el Partido Republicano, y Samuel J. Tilden, por el Partido Demócrata. Los demócratas estaban fuera de la presidencia desde el Gobierno de James Buchanan (1857-1861), pero tenían fuertes posibilidades de retornar a la Casa Blanca dada la oposición a la política republicana de la Reconstrucción y

23714 Statutes at Large 243.

238 "[N]ot a few, but nearly half the states of the Union suffered from serious deadlocks. These contests, the outcome of which was often as much a matter of chance as would be the throw of dice, aroused men's worst passions and gave rise now to insistent charges of bribery, now to riot, to assault and to threats of bloodshed, such that legislative sessions had to be held under protection of martial law. Fourteen contests lasted throughout an entire session of the legislature without affecting an election. Four states submitted to the heavy cost and inconvenience of special sessions to select Senators. Six states preferred to accept vacancies, thus losing their 'equal suffrage in the Senate,' while the country was deprived of a Senate constituted as the fathers had intended. At times legislative election led to positive and flagrant misrepresentation of the state in the Senate. To the individual state it brought a domination of state and local politics by the fierce fight for a single federal office, and interference with the work of lawmaking, ranging all the way from the exaction of a few hours of the legislators' time to the virtual annihilation of the legislature, which had been constituted to care for the interests of the state" (Haynes, 1938, p. 79-117, esp. p. 95).

239 Ver Schiller et al. (2013, pp. 835-847). 
a la depresión económica reinante. Si bien Tilden obtuvo la mayoría de los votos populares, se produjo una disputa con los emitidos en Louisiana, Florida y North Carolina, estados controlados por los republicanos. Ello comprometía el resultado del colegio electoral, en el que además se cuestionaba un voto proveniente de Oregon, ya que sin los votos objetados Tilden no llegaba a la mayoría necesaria para ser proclamado. ${ }^{240}$ Los resultados electorales fueron enviados al Congreso, que debía dirimir la cuestión. Allí, la situación política estaba dividida, pues en el 44 Congreso (1875-1877) los republicanos tenían mayoría en el Senado; y los demócratas, en el House. Para colmo, la Enmienda XII -que regula la elección presidencial- no decía exactamente a quién le correspondía decidir sobre la validez de los votos emitidos. Naturalmente, si la decisión recaía en el Senado, el ganador sería Hayes, en tanto que el House le daría el triunfo a Tilden.

Cada cámara designó entonces sendas comisiones para estudiar el problema, pero tampoco se avanzó mucho. La del Senado encontraba soluciones favorables a Hayes y los representantes propiciaban las que le daban el triunfo a Tilden. Alguien sugirió entonces que una comisión de jueces de la Corte Suprema resolviera la cuestión, simulando con ello que estos no obrarían motivados por preferencias partidarias, pero la propuesta fracasó porque cada partido pretendía tener una mayoría de jueces propios en la comisión. Finalmente, se sancionó una ley que creó una Comisión Electoral, ${ }^{241}$ integrada por quince miembros: cinco por el Senado, cinco por el House y cinco jueces de la Corte Suprema. La ley establecía, además, el método a ser empleado para contar los votos.

Era obvio que los integrantes del Senado tendrían mayoría republicana; y los del House, mayoría demócrata, de modo que el delicado equilibrio residía en la selección de los jueces de la Corte. Para evitar lo que en definitiva resultó inevitable, la ley dispuso que se elegirían cuatro jueces, quienes, a su vez, designarían al quinto. Si bien la elección de cada juez se hizo en función de los distritos judiciales que cada uno de ellos presidía - para dar con ello una apariencia de representación territorial-, lo cierto es que en la práctica ello aseguró la presencia de dos republicanos y dos demócratas: por los primeros fueron elegidos los jueces Samuel Miller y William Strong; y por los demócratas, los jueces Nathan Clifford y Stephen Field.

En síntesis, el acuerdo político plasmado permitía que la Comisión Electoral se constituyera con siete republicanos y siete demócratas. Si cada uno de ellos votaba

240 Tilden obtuvo 4301000 votos populares y Hayes solamente 4036000 , pero en el colegio electoral Hayes aventajaba a su oponente por un solo voto: tenía 185 votos contra 184 de Tilden.

241 Electoral Commission Act, 19 Statutes at Large 227. 
por el candidato de su partido, lo cual era esperable, la elección presidencial quedaba en definitiva en manos del juez de la Corte Suprema elegido por sus propios colegas. Parecía que la elección recaería en David Davis, ${ }^{242}$ cuyas vacilaciones políticas no permitían determinar exactamente cuál partido prefería, aunque era probable que se inclinara por Tilden. ${ }^{243}$ En el ínterin, Davis fue electo senador por Illinois y renunció a la Corte. Si bien su renuncia se haría efectiva recién en marzo de 1877, lo que le daba tiempo para cumplir la tarea en la Comisión, declinó el ofrecimiento de integrarla. ${ }^{244}$ La elección recayó entonces en Joseph Bradley, el menos partisano de los jueces -pero republicano al fin-, quien votó por el candidato de su partido dándole el triunfo a Hayes, que, naturalmente, llegó a la presidencia muy debilitado políticamente en medio de las fuertes críticas de los demócratas, dirigidas en especial contra Bradley. Estos, no obstante, decidieron acatar la decisión luego de celebrar el Compromiso de 1870, un acuerdo no escrito por medio del cual, en esencia, los republicanos se comprometieron a retirar las tropas federales de los estados del sur. Con ello concluyó la Reconstrucción y los afroamericanos quedaron a merced de los Gobiernos sureños, hostiles a sus libertades, sin ayuda del gobierno nacional. Desde entonces, y hasta la sanción de la Civil Rights Act de 1964, los demócratas controlaron férreamente lo que se denominó el Bloque del Sur (Southern Bloc), integrado por los dieciséis estados ubicados en el sudeste y en el centro sud del país, a los que se les sumó el Distrito de Columbia. ${ }^{245}$

\section{El gobierno de los partidos (1877- 1919) \\ 8.1. Cuatro décadas de reparto político más equilibrado}

Los 21 congresos que tuvieron lugar entre 1877 y 1919 muestran un panorama político mucho más equilibrado que el del período anterior. Si bien puede decirse que los republicanos tuvieron preponderancia, los demócratas, fortalecidos en el sur después de la Reconstrucción, equilibraron esa fuerza. En el

242 Designado por Abraham Lincoln en 1862, había hecho su carrera política en Illinois, donde había sido diputado, convencional constituyente y luego juez.

243 Era un republicano moderado, oriundo de Maryland y establecido en Illinois, que se convirtió en el director de la campaña presidencial de Lincoln, esfuerzo que luego fue premiado con una designación en la Corte Suprema en 1862. En 1872 había apoyado al Liberal Republican Party, que se oponía a la reelección de Ulysses Grant, cuya candidatura sostenían los republicanos radicales.

244 Parece ser, incluso, que los republicanos apoyaron su candidatura, pues la elección como senador desnudaba su partidismo y lo descalificaba como supuesto miembro independiente de la Comisión.

245 Esos estados son: Delaware, Florida, Georgia, Maryland, North Carolina, South Carolina, Virginia, West Virginia, Alabama, Kentucky, Mississippi, Tennessee, Arkansas, Louisiana, Oklahoma y Texas. 
cuadro siguiente se puede ver qué partido tuvo la mayoría en cada uno de los congresos que tuvieron lugar en el período aquí considerado. Esta muestra indica que en el Senado predominaron los republicanos, pues tuvieron mayoría en 16 de los 22 congresos, mientras que en el House las mayorías se repartieron por mitades, con 11 congresos para cada partido. ${ }^{246}$

\begin{tabular}{c|c|c}
\hline Congreso & Mayoría en el Senado & Mayoría en el House \\
\hline $45^{\circ}(1877-1879)$ & Republicana & Demócrata \\
\hline $46^{\circ}(1879-1881)$ & Demócrata & Demócrata \\
$47^{\circ}(1881-1883)$ & Dividida & Republicana \\
$48^{\circ}(1883-1885)$ & Republicana & Demócrata \\
$49^{\circ}(1885-1887)$ & Republicana & Demócrata \\
$50^{\circ}(1887-1889)$ & Republicana & Demócrata \\
$51^{\circ}(1889-1891)$ & Republicana & Republicana \\
$52^{\circ}(1891-1893)$ & Republicana & Demócrata \\
$53^{\circ}(1893-1895)$ & Demócrata & Demócrata \\
$54^{\circ}(1895-1897)$ & Republicana & Republicana \\
$55^{\circ}(1897-1899)$ & Republicana & Republicana \\
$56^{\circ}(1899-1901)$ & Republicana & Republicana \\
$57^{\circ}(1901-1903)$ & Republicana & Republicana \\
$58^{\circ}(1903-1905)$ & Republicana & Republicana \\
$59^{\circ}(1905-1907)$ & Republicana & Republicana \\
$60^{\circ}(1907-1909)$ & Republicana & Republicana \\
$61^{\circ}(1909-1911)$ & Republicana & Republicana \\
$62^{\circ}(1911-1913)$ & Republicana & Demócrata \\
$63^{\circ}(1913-1915)$ & Demócrata & Demócrata \\
$64^{\circ}(1915-1917)$ & Demócrata & Demócrata \\
$65^{\circ}(1917-1919)$ & Demócrata & Demócrata \\
\hline & & \\
\hline
\end{tabular}

246 Un dato de color de este período es que en el 47 Congreso (1881-1883) el Senado estuvo dividido en dos mitades iguales, con 37 senadores cada partido y dos independientes: David Davis, de Illinois, que votaba con los demócratas, y William Mahone, de Virginia, que se inclinaba por los republicanos. Este empate, en definitiva, favorecía a los republicanos, pues Chester Arthur, el vicepresidente republicano, ejercía el casting vote votando a favor de su partido. Esta situación produjo una ardua disputa por el reparto de las comisiones al comienzo de la primera sesión en marzo de 1881 . 
Un segundo dato a tener en cuenta sobre este período es que la Casa Blanca, ocupada mayoritariamente por presidentes republicanos, no tuvo grandes figuras, salvo las de Theodore Roosevelt (1901-1909) y Woodrow Wilson (19131921). ${ }^{247}$ Sin la influencia de líderes fuertes en el Ejecutivo, el Congreso y los partidos emergieron políticamente, ejerciendo un poder que coincidía con lo que el propio Wilson, en su temprana juventud, predicaba en su obra Congressional Government, publicada originalmente en $1885,{ }^{248}$ en la que sostenía que la tarea principal de gobierno le corresponde al Congreso. ${ }^{249}$ Es probable que Wilson haya tenido oportunidad de meditar sobre estas afirmaciones años después, en 1919, siendo presidente, cuando un Senado hostil rechazó la aprobación del Tratado de Versailles, frustrando su propósito de incorporar a los Estados Unidos a la Liga de Naciones, tratado que el propio Wilson había ido en persona a defender en el recinto, haciendo un gesto extravagante que, ya en 1789, había resultado insatisfactorio incluso para Washington. ${ }^{250}$

\subsection{El crecimiento cuantitativo del Congreso}

Durante este período, el Congreso tuvo un importante incremento cuantitativo de sus miembros. El House, que en 1877 comenzó con 293 representantes, alcanzó en 1913 los 435, como consecuencia del aumento de la población registrada en cada Censo, número este que, como veremos luego, se mantiene fijo hasta el presente por imposición de la Permanent Apportionment Act of 1929. El Senado, por su lado, creció de 76 a 96 senadores en virtud de la incorpora-

247 En el Anexo VII (p. 440) trazo una semblanza de estos presidentes

248 He consultado la edición publicada por Okitos Press (Wilson, 2017).

249 Ya desde el prefacio de la obra Wilson (2017) dice que el Congreso es el poder predominante y central del sistema, y al formular sus conclusiones sostiene que este rápidamente se está convirtiendo en el cuerpo gobernante de la nación que posee el poder de legislar que lubrica el Gobierno. ("Congress is fast becoming the governing body of the nation, and yet the only power which it possesses in perfection is the power which is but a part of government, the power of legislation. Legislation is but the oil of government. It is that which lubricates its channels and speeds its wheels; that which lessens the friction and so eases the movement").

250 El 22 de agosto de 1789, acompañado por Henry Knox, su secretario de Guerra, Washington concurrió personalmente al Senado para urgir la firma de un tratado con los indigenas de la tribu Creek en el sur. Según el relato del senador William McClay de Pennsylvania, no solo el ruido de los carruajes que circulaba por la calle impedía escuchar bien a Washington, sino que los senadores, en lugar de aprobar inmediatamente el tratado, como Washington esperaba, lo enviaron a comisión para estudiarlo, un gesto que irritó al presidente. Finalmente, lo aprobaron la semana siguiente. A partir de entonces, todas las comunicaciones entre Washington y el Senado se hicieron por escrito. Vid. Guide to Congress (2015, p. 77). 
ción de 10 nuevos estados. ${ }^{251}$ En el cuadro siguiente se muestra esta evolución en cada una de las cámaras.

\begin{tabular}{c|c|c}
\hline Congreso & Senadores & Representantes \\
\hline $45^{\circ}(1877-1879)$ & 76 & 293 \\
$46^{\circ}(1879-1881)$ & 76 & 293 \\
$47^{\circ}(1881-1883)$ & 76 & 325 \\
$48^{\circ}(1883-1885)$ & 76 & 325 \\
$49^{\circ}(1885-1887)$ & 76 & 325 \\
$50^{\circ}(1887-1889)$ & 76 & 325 \\
$51^{\circ}(1889-1891)$ & 88 & 332 \\
$52^{\circ}(1891-1893)$ & 88 & 332 \\
$53^{\circ}(1893-1895)$ & 88 & 356 \\
$54^{\circ}(1895-1897)$ & 90 & 357 \\
$55^{\circ}(1897-1899)$ & 90 & 357 \\
$56^{\circ}(1899-1901)$ & 90 & 357 \\
$57^{\circ}(1901-1903)$ & 90 & 357 \\
$58^{\circ}(1903-1905)$ & 90 & 386 \\
$59^{\circ}(1905-1907)$ & 90 & 386 \\
$60^{\circ}(1907-1909)$ & 92 & 391 \\
$61^{\circ}(1909-1911)$ & 92 & 391 \\
$62^{\circ}(1911-1913)$ & 96 & 394 \\
$63^{\circ}(1913-1915)$ & 96 & 435 \\
$64^{\circ}(1915-1917)$ & $95^{\circ}(1917-1919)$ & 96 \\
$66^{\circ}(1919-1921)$ & 96 & \\
\hline
\end{tabular}

\subsection{Los party bosses en el Senado}

Luego de la Guerra Civil, entró al Senado una nueva camada de legisladores. Ninguno de ellos tenía la brillantez oratoria de Daniel Webster o Henry Clay,

251 En orden cronológico, los estados incorporados fueron: Montana (1889), North Dakota (1889), South Dakota (1889), Washington (1889), Idaho (1890), Wyoming (1890), Utah (1896), Oklahoma (1907), Arizona (1912) y New Mexico (1912). 
sino que eran políticos profesionales que habían emergido de las filas de sus partidos en cada uno de los estados y que llegaron a Washington luego de haber consolidado su poder en las respectivas estructuras partidarias, cuya disciplina interna y armonía estaban bien dispuestos a mantener y controlar.

Para estos hombres, el Senado era un escalón en su carrera política y se los veía como resultado del crecimiento del poder de los partidos, atribuido, en buena medida, a los trusts, es decir, a las empresas económicamente monopólicas que los apoyaban y se valían de ellos para preservar sus intereses por medio de fuertes lobbies. ${ }^{252}$ Como resultado de ello, el Senado perdió estima popular y se lo calificó como el "Club de los Millonarios" (Millionaires Club), una denominación que fue acuñada hacia $1890 .{ }^{253}$ Con el control del Senado por parte de los "jefes del partido" (party boses), la discusión parlamentaria descendió en calidad, pues las cuestiones ya llegaban acordadas al recinto y las sesiones carecían de brillo, transformándose en actos formales de aprobación de lo ya decidido previamente. ${ }^{254}$ Todo ello generó el ambiente propicio para gestar una reforma en el procedimiento de elección de los senadores, que ya había tenido, como vimos, una primera modificación -no muy exitosa- en la ley de 1866 y que se concretó finalmente con la Enmienda XVII, a la que me referiré más abajo.

Representantes típicos de esta disciplina partidaria fueron los senadores republicanos Orville H. Platt, de Connecticut, John C. Spooner, de Wisconsin, Nelson W. Aldrich, de Rhode Island, James McMillan, de Michigan, y William B. Allison, de Iowa. Este último, a lo largo de tres décadas en la banca (18811911), encontró la forma de consolidar su poder por medio del empleo del caucus, ${ }^{255}$ lo que le permitió influir decisivamente en el nombramiento de quienes eran afines a sus intereses en las comisiones legislativas. ${ }^{256}$ En las filas demócratas, el senador más influyente, como contraparte de Allison, fue Arthur

\section{Ver Rothman (1966).}

253 Ver Patrick et al. (2001, p. 411).

254 El senador republicano George F. Hoar, de Massachusetts, decía que ser senador sería encantador si no hubiera que asistir a las sesiones (como se citó en Rothman, 1966, p. 146).

255 Se entiende por caucus, cuyo nombre oficial en la actualidad es Legislative Service Organization, a la reunión u organización de un cierto número de legisladores con un propósito determinado. Tanto su origen histórico como etimológico son imprecisos. La palabra caucus, entendida como "club político", aparece en el diario de John Adams en 1763 y se dice que proviene de caucauasu, que entre los indígenas algonquin era una reunión del consejo tribal. Vid. Dickson y Clancy (1993, pp. 49-50).

256 Allison también controlaba el llamado Steering Committe de los republicanos en el Senado, es decir, la "comisión de dirección", que se encargaba de controlar la marcha de los proyectos legislativos. En el Senado, los integrantes de esta comisión eran designados por períodos bianuales desde 
P. Gorman, de Maryland, que tuvo también una larga trayectoria (1881-1899 y 1903-1906), aunque su influencia fue menor, dada la mayoría republicana que dominó el Senado durante este período.

\subsection{La práctica del filibuster en el Senado y la Cloture Rule}

En la jerga parlamentaria, el filibuster (filibustero) es la antigua práctica de entorpecer y tratar de evitar el proceso de discusión y sanción de una ley por medio de largos e innecesarios discursos que dilatan extraordinariamente las sesiones. ${ }^{257}$ Usualmente, es el recurso empleado por los legisladores de la minoría para obstruir los proyectos de la mayoría. ${ }^{258}$ Con ello se asocia a quienes lo practican con los piratas o bandidos que atacaban las naves comerciales, que tuvieron su auge en el siglo XVIII. ${ }^{259}$ En lenguaje sencillo, quien hace un filibuster "piratea" la sesión.

Si bien esta táctica ya había sido empleada en el Senado antes y durante la Guerra Civil, ${ }^{260}$ a partir de 1880 su uso fue mucho más intenso, favorecido por la antigua regla de que los discursos no tenían un tiempo limitado de duración. Ya a finales de la década de 1870, los republicanos la emplearon para obstruir los proyectos demócratas de retiro de las tropas federales en el sur y, en 1881, los demócratas se valieron del filibuster para impedir que el Senado se organizara hasta que renunciaran los senadores republicanos de New York Roscoe Conckling y Thomas C. Platt. Por tal motivo, el Senado estuvo virtualmente paralizado desde el 24 de marzo hasta el 16 de mayo de ese año. Un caso curioso fue el de Henry W. Blair, senador republicano por New Hampshire, que en 1890 presentó un proyecto de ley de subsidios a la educación y, entre el 26 de febrero y el 20 de marzo, se ocupó de dilatar su tratamiento en aras de lograr la mayoría para su aprobación, la cual finalmente no obtuvo. ${ }^{261}$ Fue

mediados de 1880 .

257 Tan antigua es que, en Roma, Catón el Joven la empleó en el Senado, hablando días y días para oponerse a las leyes de Julio César.

258 En el Congreso de los Estados Unidos, el récord lo tiene el entonces senador demócrata por South Carolina Strom Thurmond, quien, para impedir la sanción de la Civil Rights Act of 1957, habló durante 24 horas y 27 minutos en la sesión del 30 de agosto de 1957.

259 La palabra viene del holandés (vrijbuiter), que podría traducirse al inglés como freebooter.

260 Fue empleada en 1863 para intentar que Lincoln no fuera sancionado por la suspensión del hábeas corpus, y en 1865 el senador Charles Sumner de Massachusetts hizo uso de ella para impedir que Louisiana fuera reincorporada a la Unión.

261 El proyecto fue rechazado por un voto de 37-31 y el propio Blair votó en contra para tener la 
célebre también el filibuster de los demócratas contra el llamado Force Bill, que autorizaba la supervisión de las autoridades nacionales en las elecciones de los estados sureños para impedir que los afroamericanos fueran excluidos de votar. Luego de siete semanas de dilación, transcurridas entre el 2 de diciembre de 1890 y el 26 de enero de 1891, los republicanos intentaron sin éxito imponer una regla de cierre o clausura a los debates (cloture rule), pero no les fue posible. Finalmente, abandonaron el proyecto porque la parálisis del Senado estaba impidiendo la aprobación de otras leyes antes de que terminaran las sesiones del 51 Congreso. Dos años después, en 1893, también fue objeto de un largo filibuster la derogación de la Silver Purchase Act of 1890, que se prolongó entre el 29 de agosto y el 24 de octubre, ${ }^{262}$ provocando una fuerte crítica del senador republicano Henry Cabot Lodge, de Massachusetts, quien señaló la necesidad de establecer un cambio en el reglamento que impidiera estas demoras, pues un Senado paralizado no puede gobernar. ${ }^{263}$ Los ejemplos históricos podrían seguir, pero mencionaré solamente dos más. El primero de ellos figura entre los filibusters más prolongados: el del senador republicano Robert M. La Follette, de Wisconsin, ${ }^{264}$ producido en 1908 , que se extendió por 18 horas para impedir la sanción de un proyecto presentado por su propio partido ${ }^{265}$ relativo al Money Trust (el monopolio de los bancos). ${ }^{266}$ El segundo tuvo lugar en 1917, cuando el Senado obstruyó un proyecto del presidente Wilson para armar buques mercantes en preparación para la próxima intervención de los Estados Unidos en la Primera Guerra Mundial, provocando la ira del presidente. ${ }^{267}$

posibilidad de pedir la reconsideración del proyecto, lo que tampoco logró.

262 En esta ocasión se emplearon todas las técnicas posibles de dilación en una asamblea legislativa, entre ellas, el llamado roll-call vote, o recorded vote, que consiste en que el voto de cada legislador queda registrado con su nombre, a diferencia del ballot vote, que es secreto, pues se vota por medio de una boleta depositada en una urna sin indicación de quién lo emite.

263 Citado por Haynes (1938, pp. 398-399).

264 Famoso por su energía, se lo conocía como Fighting Bob (Roberto el Luchador).

265 Sus impulsores fueron el senador Aldrich, ya mencionado, y Edward B. Vreeland, representante de New York.

266 Empleando el filibuster, La Follette logró introducir en la ley una enmienda que penaba el envío de información bancaria inexacta al Gobierno. Ver Thelen (1976a, pp. 64-66).

267 "The Senate of the United States -dijo Wilson- is the only legislative body in the world which cannot act when its majority is ready for action. A little group of willful men, representing no opinion but their own, have rendered the great government of the United States helpless and contemptible" (Haynes, 1938, pp. 402-403).

Una vez más, Wilson debe de haberse arrepentido de lo que escribiera años antes como profesor universitario en Congressional Government, elogiando la posibilidad de hablar en el Senado abierta e irrestrictamente. Ver Wilson (2017, p. 70). 
Fue precisamente a raíz de este último filibuster que el Senado incorporó la Regla XXII, llamada Cloture Rule (del francés clôture: cierre, clausura). Según esta, los debates podían ser concluidos si lo votaba una mayoría de dos tercios de los senadores presentes. ${ }^{268}$

A diferencia del Senado, en el House el filibuster no se ha extendido como práctica. Si bien los hubo antiguamente, antes incluso que en el Senado, el mayor tamaño de la cámara obligó a establecer varias reglas tendientes a evitarlos. Así, por ejemplo, desde 1798 fue establecido que cada representante puede hablar una sola vez en cada debate y, en 1847 , se dispuso que las intervenciones relativas a enmiendas en los proyectos solo pueden durar cinco minutos.

\subsection{El caso Kilbourn v. Thompson y la revisión de las investigaciones del Congreso}

En 1881, la Corte Suprema resolvió el caso Kilbourn v. Thompson, ${ }^{269}$ que delimitó los alcances de los poderes de investigación del Congreso. Con motivo de la investigación de la quiebra Jay Cooke \& Company -una de las compañías financieras más importantes de ese momento-, ${ }^{270}$ producida por la crisis económica de 1873 (Panic of 1873), ${ }^{271}$ Hallet Kilbourn, un agente inmobiliario vinculado comercialmente con la compañía en quiebra, fue citado a declarar como testigo por la comisión investigadora establecida por el House. ${ }^{272} \mathrm{Si}$ bien Kilbourn se presentó ante la comisión investigadora, se negó a declarar y a producir la prueba que se le requirió. A raíz de esta negativa, fue arrestado por desacato (contempt) y penado con 45 días de prisión por orden del House. Impugnada judicialmente esta decisión, la Corte Suprema -por medio del voto del Justice Miller- sostuvo que el Congreso no estaba conduciendo una investigación de naturaleza legislativa, sino judicial, y que por lo tanto no era competente para ello ni para ordenar tampoco, en ese contexto, el arresto de

268 En la actualidad, según una reforma introducida en 1975, la Regla XXII dispone que la petición deben formularla dieciséis senadores y la mayoría para votarla se reduce a tres quintos.

269103 U.S. 168 (1881).

270 Fundada en 1861 por Jay Cooke, había crecido extraordinariamente colocando bonos del Gobierno durante la Guerra Civil.

271 Jay Cooke \& Company había invertido fuertemente en la construcción de la Northern Pacific Railway, pero quebró cuando no pudo colocar los bonos de la compañía a causa de la crisis financiera de 1873, cuyas causas en los Estados Unidos son más profundas, pero fue desatada por la Coinage Act of 1873 (17 Statutes at Large 424), que eliminó el bimetalismo plata/dólar y puso a los Estados Unidos en el caminos del gold standard, que fue oficialmente adoptado en 1900.

272 Uno de los acreedores en la quiebra era el Gobierno de los Estados Unidos, lo que justificaba la promoción de la investigación en el Congreso. 
un testigo renuente a declarar. ${ }^{273}$ Asimismo, citando una sentencia de la Corte Suprema de Massachusetts, ${ }^{274}$ sostuvo que las decisiones emitidas en el curso de una investigación del Congreso eran revisables judicialmente. ${ }^{275}$

\subsection{La centralización del poder del Speaker. Thomas B. Reed y Joseph G. Cannon}

Por espacio de dos décadas, entre 1890 y 1910, dos figuras prominentes del Partido Republicano, Thomas Brackett Reed y Joseph Gurney Cannon, lideraron el House en forma autoritaria como Speakers y generaron una gran centralización de poder en torno a su persona.

Ya mencioné que, durante la Guerra Civil y el período de la Reconstrucción, los Speakers no dominaron el House. Schuyler Colfax (1863-1869) y quienes lo

273 "[...] we are of opinion that the House of Representatives not only exceeded the limit of its own authority, but assumed a power which could only be properly exercised by another branch of the government, because it was in its nature clearly judicial (103 U.S. en p. 192) [...] We are of opinion, for these reasons, that the resolution of the House of Representatives authorizing the investigation was in excess of the power conferred on that body by the Constitution; that the committee, therefore, had no lawful authority to require Kilbourn to testify as a witness beyond what he voluntarily chose to tell; that the orders and resolutions of the House, and the warrant of the speaker, under which Kilbourn was imprisoned, are, in like manner, void for want of jurisdiction in that body, and that his imprisonment was without any lawful authority (103 U.S. en p. 196) [...] we do not concede that the Houses of Congress possess this general power of punishing for contempt. The cases in which they can do this are very limited, as we have already attempted to show. If they are proceeding in a matter beyond their legitimate cognizance, we are of opinion that this can be shown, and we cannot give our assent to the principle that, by the mere act of asserting a person to be guilty of a contempt, they thereby establish their right to fine and imprison him, beyond the power of any court or any other tribunal whatever to inquire into the grounds on which the order was made. This necessarily grows out of the nature of an authority which can only exist in a limited class of cases, or under special circumstances; otherwise the limitation is unavailing and the power omnipotent" (103 U.S. en p. 197).

274 Burnham v. Morrissey, 14 Gray 226 (1859).

275 "The house of representatives is not the final judge of its own power and privileges in cases in which the rights and liberties of the subject are concerned, but the legality of its action may be examined and determined by this court. That house is not the legislature, but only a part of it, and is therefore subject in its action to the laws, in common with all other bodies, officers, and tribunals within the Commonwealth. Especially is it competent and proper for this court to consider whether its proceedings are in conformity with the Constitution and laws, because, living under a written constitution, no branch or department of the government is supreme; and it is the province and duty of the judicial department to determine in cases regularly brought before them, whether the powers of any branch of the government, and even those of the legislature in the enactment of laws, have been exercised in conformity to the Constitution; and if they have not, to treat their acts as null and void. The house of representatives has the power under the Constitution to imprison for contempt; but the power is limited to cases expressly provided for by the Constitution, or to cases where the power is necessarily implied from those constitutional functions and duties, to the proper performance of which it is essential" (103 U.S. en p. 199). 
sucedieron -Theodore Pommeroy (1869), ,276 James G. Blaine (1869-1875), $277 \mathrm{Mi}$ chael Kerr (1875-1876), ${ }^{278}$ Samuel J. Randall (1876-1881), ${ }^{279}$ Warren Kiefer (18811883), ${ }^{280}$ y John Carlisle (1883-1889) - no ejercieron el control de la Cámara. ${ }^{281}$ Esta situación tuvo un giro importante en el 51 Congreso (1889-1891), cuando los republicanos retomaron el control del House y eligieron como Speaker a Thomas Brackett Reed, de Maine, quien ocuparía el cargo en tres oportunidades: 1889-1891, 1895-1897 (54º Congreso) y 1897-1899 (55 Congreso). ${ }^{282}$

Reed era un individuo alto y fornido, vestido siempre de negro, que tenía un temperamento fuerte, con el que rápidamente se hizo del control del House. ${ }^{283}$ Para ello, impuso de inmediato, casi por la fuerza, las llamadas Reed Rules sobre el cómputo del quorum -luego incorporadas en forma permanente- para evitar que la minoría pudiera obstruir las sesiones no dando el quorum necesario para votar. La ocasión para ello se presentó en enero de 1890, cuando John Dalzell, de Pennsylvania, propuso como cuestión de privilegio que fuera tratado el caso de la elección de Charles Brooks Smith, republicano de West Virginia, que estaba en disputa. Esto provocó la reacción negativa de Charles F. Crisp, de Georgia, líder de la oposición. Sometida la cuestión a votación por medio del roll-call vote, es decir, registrando los nombres de los que votaban en uno y otro sentido, ${ }^{284}$ votaron 161 en sentido afirmativo, solo 2 votaron por el no y 166 se abstuvieron. Reed decidió, entonces, que el quorum debía computarse contando también a los presentes que no habían votado y que la votación se había llevado a cabo correctamente. Planteada la revisión de esta decisión, la moción fue rechazada por mayoría. ${ }^{285}$

\footnotetext{
276 Republicano de New York.

277 Republicano de Maine.

278 Demócrata de Indiana.

279 Demócrata de Pennsylvania.

280 Republicano de Ohio.

281 Demócrata de Kentucky.
}

282 Había ingresado al House en el 45 Congreso (1877-1879) y luego fue reelecto como representante

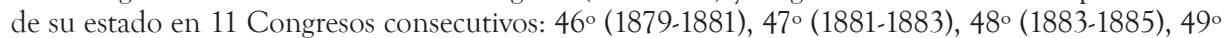
(1885-1887), 50॰ (1887-1889), 51。 (1889-1891), 52。 (1891-1893), 53。 (1893-1895), 54 (1895-1897), 55 (1897-1899) y 56 (1899-1901). Antes de ello, había sido miembro del House en Maine (18681869), senador estatal (1870) y Attorney General de Maine (1870-1872).

283 Desde Henry Clay, que dominó el House como Speaker en cinco Congresos (12 1811-1813; 13 1813-1814; 14 1815-1817; 15॰ 1817-1819 y 16 1819-1820), no se había visto a un líder semejante. La oposición rápidamente lo calificó de "tirano" y "zar".

284 Ver nota 262.

285 Justificó la decisión diciendo, en síntesis, que el objetivo del Congreso no era obstruir la legislación, 
Un mes más tarde, esta regla fue incorporada al reglamento del House por el Rules Committee y fue aprobada por el pleno por una mayoría de 161-144. Adicionalmente, en el nuevo reglamento se dispuso reducir el quorum para las sesiones de la Comisión del Pleno (Committee of the Whole House) de la mitad de los miembros a solo 100, lo que agilizó las sesiones, teniendo en cuenta el crecimiento constante del número de representantes. ${ }^{286}$ Se dispuso también que la presentación de un proyecto ya no requeriría la autorización del House (leave of the House), sino que era suficiente su presentación ante el Clerk. ${ }^{287}$ Bajo estas nuevas reglas, se le permitió al Speaker tener el control del House. Podía designar a todos los miembros de las comisiones, premiando con ello a sus adláteres y castigando a sus opositores, y presidía las dos comisiones más importantes: la de reglamento (Rules Committee) y la de presupuesto (Committee on Ways and Means and Appropiations).

Cuando en el 52॰ Congreso (1891-1893) los demócratas recobraron la mayoría en el House, derogaron las Reed Rules, pero, dándose cuenta de lo efectivas que eran para quien tuviera la mayoría, las restablecieron en el $53^{\circ}$ Congreso (1893-1895), en el que también fueron mayoría. En este período, Charles F. Crisp, como Speaker, hizo amplio uso de ellas, incluso en contra de Reed. Bajo estas reglas, durante este período, ambos partidos en el House actuaron con gran unidad interna. En el ala republicana, ello tuvo lugar, en parte, merced a que Reed, como Speaker en el 55 Congreso (1897-1899), designó como Whip (jefe de bloque) a James A. Tawney, de Minnesota, quien mantuvo el control en las votaciones, evitando que los caucus dentro del partido votaran divididos.

sino promoverla, y que la mayoría tenía el derecho de rechazar aquellas mociones, que aun estando permitidas por la práctica parlamentaria, eran dilatorias. "There is no possible way by which the orderly methods of parliamentary procedure can be used to stop legislation. The object of a parliamentary body is action, and not stoppage of action. Hence, if any member or set of members undertakes to oppose the orderly progress of business, even by the use of the ordinarily recognized parliamentary motions, it is the right of the majority to refuse to have those motions entertained, and to cause the public business to proceed" (como se citó en Guide to Congress, 2015, p. 53).

286 Ver Grant (2011).

287 Como resultado de ello, el número de proyectos presentados aumentó considerablemente. Hasta el 40॰ Congreso (1867-1869) esta cantidad nunca había excedido los 2000. En el 51 Congreso (1889-1891) fueron presentados 19000 proyectos, bien que, como anotaba Woodrow Wilson (2017), la mayoría de ellos era desechado. "The fate of bills committed is generally not uncertain. As a rule, a bill committed is a bill doomed. When it goes from the clerk's desk to a committee-room it crosses a parliamentary bridge of sighs to dim dungeons of silence whence it will never return. The means and time of its death are unknown, but its friends never see it again. Of course no Standing Committee is privileged to take upon itself the full powers of the House it represents, and formally and decisively reject a bill referred to it; its disapproval, if it disapproves, must be reported to the House in the form of a recommendation that the bill 'do no pass'” (p. 24). 
Además de la centralización del House en torno al Speaker, en los últimos años del siglo XIX tuvo lugar otro fenómeno -no tan visible- que también contribuyó a la unidad de las decisiones. Hasta la Guerra Civil, ser elegido representante no era considerado como una carrera política. La movilidad entre los legisladores era muy alta, al punto que, a fines de la década de 1870, más de la mitad de los entonces 293 representantes se renovaba en cada Congreso. Muchos de ellos solo eran elegidos por un término no mayor a dos períodos y no les interesaba demasiado su relación con el Speaker que los designaba en las comisiones, pues no tenían un alto interés en integrarlas. Hacia el final del siglo XIX, esta rotación fue moderándose, la reelección se hizo más frecuente y ocupar una banca en el House adquirió un carácter de mayor permanencia, convirtiéndose en una suerte de profesión. En 1899, por ejemplo, la cantidad de nuevos legisladores que ingresaron al 56 Congreso fue tan solo del 30\%, mientras que el promedio de duración en la banca se había incrementado a más de tres mandatos. Con ello, la actitud de los representantes hacia su puesto político cambió, la antigüedad cobró mayor importancia ${ }^{288}$ y adquirieron más interés en especializarse en ciertos temas y ocupar posiciones destacadas en las comisiones. Todo ello contribuyó, ciertamente, a cuestionar el centralismo del Speaker, quien ahora debía lidiar con políticos profesionales.

Reed renunció como Speaker en 1899 por sus desavenencias con el presidente McKinley sobre la guerra de Cuba y la anexión de Hawaii, y fue reemplazado en el 56 Congreso (1899-1901) por David Henderson, republicano de Iowa, que ejerció el cargo durante dos períodos sin mayor efectividad. En 1903, al comenzar el 58 Congreso (1903-1905), los republicanos eligieron Speaker a John G. Cannon (Uncle Joe), de Illinois, quien con sus 67 años era el mayor de todos los representantes y el más antiguo: ya tenía por entonces 28 años de servicio en el House. ${ }^{289}$ Siguiendo el ejemplo de Reed, Cannon se propuso manejar el House controlando de cerca la Comisión de Reglamento (Rules Committe) y la de Presupuesto (Ways and Means Committe). En esta última retuvo como chairman a Sereno E. Payne, de New York, que había sido designado por Henderson. Inicialmente le permitió a John Sharp Williams, líder de los demócratas, que hiciera las designaciones de sus partidarios en las comisiones, sujetas al veto el Speaker. Williams aprovechó esta oportunidad para unir a su partido y, en

288 La importancia de la antigüedad fue aumentando a medida que transcurría el siglo XX. En 1900, solamente 3 de los 391 representantes tenían acumulados más de 10 mandatos en el House; en 1971, ese número se había elevado a 87.

289 Había ingresado al House en 1873 y se había postulado sin éxito como Speaker en 1881, 1889 y 1899. 
1908, Cannon retomó la prerrogativa de hacer por sí mismo todas las designaciones, cuando James Beauchamp Clark (Champ Clark), de Missouri, sucedió a Williams como líder de la minoría.

Cannon era un conservador duro que se oponía y hacía todos los esfuerzos necesarios para bloquear la sanción de la legislación social y progresista que impulsaban, por entonces, Theodore Roosevelt desde la presidencia y la creciente ala liberal de su propio partido. Para mantener estrechas sus filas, el Speaker se encargaba de sancionar duramente a quienes no lo apoyaban en esta tarea. A raíz de ello, la palabra "canonismo" (cannonism) se convirtió en sinónimo de arbitrariedad en el uso del poder del Speaker para obstruir los proyectos de ley que no eran de su agrado. Comenzó entonces un foco de resistencia contra Cannon, que tuvo una primera asonada el 3 de marzo de 1909, a fines del 60 Congreso (1907-1909), cuando fue aprobada la llamada Calendar Wednesday Rule, según la cual todos los miércoles los presidentes de las comisiones, o quienes ellos designaran, podían informarle al pleno sobre los proyectos de ley que habían sido analizados en comisión, pero que no habían recibido aprobación del Rules Committee para ser debatidos. Días después, el 15 de marzo, al comienzo del 61 Congreso (1909-1911), un grupo de treinta representantes republicanos opositores a Cannon, liderados por George W. Norris, de Nebraska $^{290}$-aunque habían votado para reelegir al Speaker-, se aliaron con los demócratas para limitar su autoridad, bien que los resultados en esta primera oportunidad fueron magros. ${ }^{291}$ Una nueva embestida contra Cannon -esta vez exitosa- tuvo lugar al año siguiente, en marzo de 1910, cuando Norris insistió nuevamente en aprobar, con algunas reformas, la propuesta de Clark formulada el año anterior. ${ }^{292}$ Si bien Cannon se opuso férreamente a tratarla, esta vez fue derrotado por un voto decisivo y el House, finalmente, aprobó la propuesta

290 En ese momento, el House estaba compuesto por 219 republicanos y 172 demócratas.

291 La táctica para ello consistió en no continuar con la costumbre de aprobar el empleo de las reglas vigentes en el anterior Congreso, sino de establecer nuevas. A tal fin, Champ Clark, líder de los demócratas, propuso que el Speaker: (a) ya no hiciera las designaciones de los miembros de todas las comisiones, sino en solo cinco de ellas, de las cuales la única importante era la de Presupuesto; y (b) dejara de presidir la Comisión de Reglamento, cuyo tamaño debía ser triplicado, añadiéndose para ello 10 nuevos miembros. Esta propuesta dividió a los partidos, pues 28 republicanos votaron a favor y 22 demócratas -liderados por John J. Fitzgerald, de New York- en contra. Fue necesario entonces adoptar una solución intermedia, propuesta por Fitzgerald, que moderó muy tibiamente la autoridad del Speaker. La principal modificación consistió en establecer un calendario para el tratamiento de ciertas leyes de interés para algunos representantes, estableciendo dos días al mes designados específicamente a tal fin. Estas leyes podían ser tratadas sin requerirse para ello la aprobación del Speaker, pero debían ser sancionadas por unanimidad.

292 Ver nota 291. 
de Norris por una mayoría de 191-156. ${ }^{293}$ Despojado de su poder, Cannon ofreció su renuncia, pero no fue aceptada y continuó siendo Speaker hasta el final del 61 Congreso, en marzo de 1911. ${ }^{294}$ En el 62 Congreso (1911-1913), los demócratas recobraron la mayoría en el House y eligieron Speaker a Champ Clark, quien impulsó un nuevo reglamento que incorporó las reglas aprobadas en 1910. Entre ellas, se dispuso que los miembros de todas las comisiones ya no serían elegidos por el Speaker, sino por el House al comienzo de cada sesión.

Desde el 62 Congreso (1911-1913), hasta el 65 Congreso (1917-1919), los demócratas tuvieron mayoría en el House. Durante este período, el poder del Speaker declinó fuertemente. La figura dominante de los demócratas en el House, desde 1911 hasta 1915, no fue Champ Clark, el Speaker, sino Oscar W. Underwood, de Alabama, presidente de la Comisión de Presupuesto y líder de la mayoría. Las decisiones retornaron a los caucus de los partidos, y en el demócrata la autoridad de Underwood era indiscutible. ${ }^{295}$

\subsection{La Apportionment Act of 1911}

El 8 de agosto de 1911 fue sancionada la Apportionment Act of 1911, ${ }^{296}$ por medio de la cual se dispuso, siguiendo los resultados del 13 Censo llevado a cabo en 1910, que el número de representantes en el House aumentaría de 391 a 433, estableciéndose, asimismo, que ese número se incrementaría a 435 una vez que Arizona y New México fuera incorporados como estados. Dado que la

293 John M. Nelson, republicano de Wisconsin, expresó vivamente los sentimientos de sus colegas insurgentes denunciando la opresión y humillación que Cannon les había impuesto: "Have we not been punished by every means at the disposal of the powerful House organization? Members long chairmen of important committees, others holding high rank - all with records of faithful and efficient party service to their credit - have been ruthlessly removed, deposed, and humiliated before their constituents and the country because, forsooth, they would not cringe or crawl before the arbitrary power of the Speaker and his House machine [...]. We are fighting with our Democratic brethren for the common right of equal representation in this House, and for the right of way of progressive legislation in Congress" (Guide to Congress, 2015, p. 55).

294 Salvo durante el 63 Congreso (1913-1915), Cannon continuó siendo miembro del House hasta 1923.

295 George B. Galloway (1976) describió el poder de Underwood en estos términos: "As floor leader, Underwood was supreme, the Speaker a figurehead. The main cogs in the machine were the caucus, the floor leadership, the Rules Committee, the standing committees, and special rules. Oscar Underwood became the real leader of the House. He dominated the party caucus, influenced the rules and, as chairman of Ways and Means, chose the membership of the committees. Champ Clark was given the shadow, Underwood the substance, of power. As floor leader, he could ask and obtain recognition at any time to make motions, restrict debate or preclude amendments or both" (p. 136).

29637 Statutes at Large 13. 
ley se aplicaría a partir del 63 Congreso (1913-1915), el House ya contaba con 435 representantes cuando dicho Congreso fue inaugurado, en tanto Arizona y New México fueron convertidos en estados en 1912.

Conforme a esta ley, la distribución de representantes por cada estado era la siguiente:

\begin{tabular}{|c|c|c|}
\hline Alabama: 10 & Maryland: 6 & Oregon: 3 \\
\hline Arkansas: 7 & Massachusetts: 16 & Pennsylvania: 36 \\
\hline California: 11 & Michigan: 13 & Rhode Island: 3 \\
\hline Colorado: 4 & Minnesota: 10 & South Carolina: 7 \\
\hline Connecticut: 5 & Mississippi: 8 & South Dakota: 3 \\
\hline Delaware: 1 & Missouri: 16 & Tennessee: 10 \\
\hline Florida: 4 & Montana: 2 & Texas: 18 \\
\hline Georgia: 12 & Nebraska: 6 & Utah: 2 \\
\hline Idaho: 2 & Nevada: 1 & Vermont: 2 \\
\hline |llinois: 27 & New Hampshire: 2 & Virginia: 10 \\
\hline Indiana: 13 & New Jersey: 12 & Washington: 5 \\
\hline lowa: 11 & New York: 43 & West Virginia: 6 \\
\hline Kansas: 8 & North Carolina: 10 & Wisconsin: 11 \\
\hline Kentucky: 11 & North Dakota: 3 & Wyoming: 1 \\
\hline Louisiana: 8 & Ohio: 22 & \\
\hline Maine: 4 & Oklahoma: 8 & \\
\hline
\end{tabular}

A pesar de que una mayor cantidad de representantes parecería asegurar una mayor democracia, la sanción de esta ley produjo críticas basadas en que el aumento de representantes con cada censo debilitaba el sistema representativo establecido en la Constitución. Uno de los voceros de estas críticas fue Edgar 
D. Crumpacker, representante republicano de Indiana. ${ }^{297}$ Fue por ello que, como veremos más adelante, en 1929 se dictó la Permanent Apportionment Act, que fijó el número de representantes en 435, número que no ha variado hasta ahora, salvo por un breve período -entre 1959 y 1963 - en el que aumentó a 437 con la incorporación de Alaska y Hawaii como estados.

\subsection{La Enmienda XVII y la elección directa de los senadores}

Ya mencioné, al comentar la ley de 1866 sobre elección de los senadores, que el sistema de elección de estos, establecido en el artículo I, sección 3 de la Constitución, favorecía a los grupos de interés que controlaban las legislaturas estatales y producía, en ocasiones, un empate en la elección o bien una distorsión del proceso electoral. La ley de 1866 no fue efectiva para mejorar el sistema, de modo tal que, para cambiarlo sustancialmente eliminando la competencia de las legislaturas locales para elegir a los senadores, era necesaria una enmienda constitucional, que finalmente tuvo lugar en 1913 con la ratificación de la Enmienda XVII, que estableció la elección directa de los senadores. Antes de ella, en varios estados ya se habían sancionado leyes que, en forma indirecta, permitían la elección popular de los senadores. En 1912, sistemas de este tipo estaban vigentes en aproximadamente 29 estados. ${ }^{298}$

297 En su opinion: "Members are [...] supposed to reflect the opinion and to stand for the wishes of their constituents [...] If we make the ratio [of persons per Representative] too large the idea of representation becomes attenuated and less definite. The personal interest of the voter in his representative becomes less important to him, and we may lose something of the vital strength of our representative form of government". Ver: https://history.house.gov/HistoricalHighlight/Detail/35159? ret=True.

298 Hacia 1900, en los estados del sur empezó a hacerse la elección de senadores en las elecciones primarias. Por un lado, en Oregon, donde la manipulación política en la legislatura era muy grave, se sancionó en 1901 una ley por medio de la cual, al votar por los legisladores locales, los votantes podían indicar a los senadores de su preferencia. Si bien esta manifestación no era vinculante, ejercía una fuerte presión política, pues cada cámara, además, debía contar los votos populares y anunciar el nombre del candidato que había tenido el mayor número de sufragios. Luego se llevaba a cabo la elección de senador. No obstante, en la primera ocasión en la que la ley fue puesta en práctica, la legislatura eligió a un senador que no había obtenido un solo sufragio popular. Para evitar que ello volviera a ocurrir, en 1904 una nueva ley les permitió a los candidatos a cargos en la legislatura local que incluyeran en la presentación de sus candidaturas dos tipos de declaraciones. Por medio de la primera se obligaba a votar por el candidato a senador que recibiera mayor número de votos en la elección popular. Por medio de la segunda, declaraba que no estaba obligado por el voto popular. Obviamente, ningún legislador optaba por esta segunda declaración y ello favoreció en lo sucesivo una mayor transparencia, ya que en la siguiente elección la mayoría republicana tuvo que respetar la voluntad popular y designar a un senador demócrata que había obtenido el mayor número de sufragios populares. A partir de ese momento, otros estados adoptaron el sistema de Oregon, de modo que la elección indirecta prevista en 
Para resolver esta cuestión, en 1912 el Congreso sancionó la Enmienda XVII, que fue ratificada el 8 de abril de 1913 y entró en vigencia al mes siguiente. Su texto es el siguiente:

\begin{abstract}
El Senado de Estados Unidos estará compuesto por dos senadores de cada Estado, elegidos por el pueblo, por seis años; cada senador tendrá un voto. Los electores de cada Estado deberán tener las mismas calificaciones requeridas a los electores de la rama más numerosa de las Legislaturas estatales. Cuando se produzcan vacantes en la representación de cualquier Estado en el Senado, la autoridad ejecutiva de ese Estado convocará a elección para llenar las vacantes, sin perjuicio de que la Legislatura de cualquier Estado puede autorizar al Ejecutivo a hacer nombramientos temporarios hasta que el pueblo llene las vacantes por elección, en la forma dispuesta por la Legislatura. Esta enmienda no será interpretada de modo que afecte la elección o el mandato de un senador elegido antes de que entre en vigencia como parte válida de la Constitución. ${ }^{299}$
\end{abstract}

Poco después de haber sido ratificada la Enmienda XVII, un tribunal federal de Indiana estableció que si una persona posee las condiciones necesarias para votar por un senador, ese derecho no deriva solamente de la legislación local que regula la elección, sino de la Constitución federal misma. ${ }^{300}$

la Constitución fue perdiendo vigencia real. Como consecuencia de ello, el Senado empezó a nutrirse paulatinamente, con senadores surgidos de la elección popular, debilitando la posición de quienes pretendían mantener el sistema indirecto. Ver Haynes (1938, pp. 79-117).

299 "The Senate of the United States shall be composed of two Senators from each State, elected by the people thereof, for six years; and each Senator shall have one vote. The electors in each State shall have the qualifications requisite for electors of the most numerous branch of the State legislatures. When vacancies happen in the representation of any State in the Senate, the executive authority of each State shall issue writs of election to fill such vacancies: Provided that the legislature of any State may empower the executive thereof to make temporary appointments until the people fill the vacancies by election as the legislature may direct. This amendment shall not be so construed as to affect the election or term of any Senator chosen before it becomes valid as part of the Constitution".

300 "The right to vote for a member of Congress being a right secured by the Constitution, and laws of the United States, it is perfectly plain that the right to vote for a United States Senator, since the adoption of the seventeenth amendment to the United States Constitution and the passage by Congress of the act of June 4, 1914, is also a right secured by the Constitution and laws of the United States. If the right to vote for a Representative in Congress or a Senator of the United States is a right secured by the Constitution and laws of the United States, then it appears that the right and privilege to serve as a member of an election board where such Representative or Senator is to be elected is likewise a right or privilege secured by the Constitution and laws of the United States. If a man has a right to vote, he has a right to have his vote received and counted by the proper election officers; otherwise, the right to vote is but an empty right". United States v. Aczel, 219 F. 917 (U.S. District Court for the District of Indiana, 1915). 


\subsection{Jeannette Rankin, la primera mujer legisladora}

El 2 de abril de 1917 puede ser celebrado como una jornada de triunfo cívico para las mujeres. Ese día, Jeannette Rankin, republicana de Indiana, juró como representante en el House, convirtiéndose en la primera legisladora del Congreso de los Estados Unidos. ${ }^{301}$ Desde entonces y hasta el 117 ${ }^{\circ}$ Congreso (20212023), 378 mujeres han sido senadoras o representantes y, algunas de ellas, han ocupado bancas en ambas cámaras. ${ }^{302}$

\subsection{El presidente Woodrow Wilson y el Congreso}

Durante sus dos períodos como presidente (1913-1921), Woodrow Wilson revivió la antigua costumbre de Washington y Adams, luego abandonada por Jefferson y los mandatarios siguientes, de concurrir personalmente al Congreso con el objetivo de impulsar la legislación que le interesaba, trabajando en ello muy estrechamente con los líderes demócratas en ambas cámaras. Inicialmente, estos esfuerzos fueron exitosos en el orden interno, pues en el $63^{\circ}$ Congreso (1913-1915) Wilson logró que fueran sancionadas leyes importantes en materia impositiva, ${ }^{303}$ bancaria, ${ }^{304}$ antimonopólica ${ }^{305}$ y de regulación económica. ${ }^{306}$

En cambio, no tuvo igual suerte en materia internacional, en la que, ya desde el comienzo, enfrentó la oposición de su propio partido. Cham Clark, el Speaker, y Oscar W. Underwood, líder de la mayoría demócrata en el House, confrontaron con Wilson sobre su política respecto al peaje (toll) en el canal de Panamá, recién abierto por el propio Wilson, coronando de esa manera los

301 Nacida en 1880 y fallecida en 1973, Rankin fue toda su vida una activa trabajadora social, sufragista y pacifista. Se opuso tenazmente a la entrada de los Estados Unidos en ambas guerras mundiales y en la Guerra de Vietnam. Fue representante por su estado en el 65 Congreso (1917-1919) y en el 77 Congreso (1941-1943). Ver Lopach y Luckowski (2018).

302 De ese total, 337 (221 demócratas y 116 republicanas) han sido representantes, 41 (25 demócratas y 16 republicanas) han sido senadoras y 17 (11 demócratas y 6 republicanas) han estado en ambas cámaras. Si se suman las delegadas sin voto provenientes de los territorios (Guam, Samoa, Islas Vírgenes), del Distrito de Columbia y de Puerto Rico, el número llega a 395. Vid. Women in Congress: Statistics and Brief Overview (2021).

303 Revenue Act of 1913, 38 Statutes at Large 114, que impuso el income tax (impuesto a las ganancias) en el orden federal y redujo los derechos aduaneros.

304 Federal Reserve Act of 1913, 38 Statutes at Large 251, por medio de la cual se creó el banco central (Federal Reserve).

305 Clayton Antitrust Act of 1914, 38 Statutes at Large 730.

306 Federal Trade Commission Act of 1914, 15 USC §§ 41-58. 
esfuerzos comenzados por Theodore Roosevelt. ${ }^{307}$ También tuvo dificultades para declararle la guerra a Alemania en 1917 e imponer la conscripción obligatoria, en la que enfrentó la oposición de Claude Kitchin, de North Carolina, que había sucedido a Underwood como líder de la mayoría demócrata, bien que esta oposición fue luego superada por amplia mayoría. ${ }^{308}$ Pero su mayor derrota en política internacional tuvo lugar en noviembre de 1919 y en marzo de 1920, cuando el Senado, con mayoría republicana liderada por Henry Cabot Lodge, un antiguo rival de Wilson, ${ }^{309}$ rechazó la aprobación del Tratado de Versailles y el ingreso de los Estados Unidos a la Liga de Naciones, que el propio Wilson había impulsado con toda energía. Esta derrota, que afectó gravemente su salud, marcó el fin de su carrera política. ${ }^{310}$

\section{Un interregno republicano (1919-1933)}

\subsection{El dominio del Partido Republicano}

Desde 1919 hasta 1933, el dominio de la escena política por parte de los republicanos fue abrumador. No solo tuvieron mayoría en ambas cámaras en

307 Ver Baker (1966, pp. 279-293).

308 El único voto en el House en contra de que Estados Unidos entrara en la Primera Guerra Mundial fue el de Jeannette Rankin.

309 Por entonces, Henry Cabot Lodge tenía una larga trayectoria legislativa. Fue senador por Massachusetts por más de 30 años (1893-1924) y presidía la Comisión de Relaciones Exteriores del Senado.

310 Wilson había ido personalmente al Senado a entregar el Tratado y defenderlo en el mes de julio de 1919. Cuando entró al recinto, él mismo llevaba el documento bajo su brazo derecho. Pero, probablemente por su entusiasmo y sus ansias personales de liderar el nuevo orden mundial emergente de la "Gran Guerra", había cometido el error político de negociarlo y firmarlo sin consultar con los líderes republicanos, a quienes había ignorado abiertamente. Luego de su discurso, que duró unos 40 minutos, se encontró con una actitud hostil por parte de los senadores de la oposición. Entre sus opositores, además de Henry C. Lodge, estaban William Borah, de Idaho, Robert La Follette, de Wisconsin, y Hiram Johnson, de California, que integraban el grupo de los "Irreconciliables". Pero Wilson había jugado sus cartas a todo o nada, señalando la necesidad imperiosa de aprobar el Tratado ("The stage is set, the destiny disclosed. It has come about by no plan of our conceiving, but by the hand of God. We cannot turn back. The light streams on the path ahead, and nowhere else") y la respuesta que obtuvo en ese momento fue muy fría, apenas un aplauso de compromiso. Lodge y su grupo habían formulado 14 reservas al Tratado, que Wilson no estaba dispuesto a negociar. Entonces, inició en septiembre una campaña por casi todo el país en busca de apoyo, que lo agotó por completo. En octubre sufrió un derrame cerebral que lo dejó parcialmente paralizado y apenas pudo hacerse cargo del Gobierno. Las comunicaciones con sus asesores las hacía a través de su mujer, a quien se la empezó a llamar la "primera presidenta de los Estados Unidos". Con sus fuerzas muy debilitadas, Wilson no tuvo posibilidad alguna ya de continuar defendiendo el Tratado, que fue rechazado en las dos oportunidades que fue objeto de tratamiento: el 19 de noviembre de 1919 y el 19 de marzo de 1920. Ver Hazelgrove (2016). 
todos los congresos hasta $1931,{ }^{311}$ sino que los tres presidentes de este período, Warren G. Harding (1921-1923), Calvin Coolidge (1923-1929) y Herbert Hoover (1929-1933), fueron republicanos. La Corte Suprema, por su lado, estuvo integrada por una mayoría de jueces de tendencia netamente conservadora ${ }^{312}$ que se mantendría hasta 1937, cuando Franklin D. Roosevelt comenzó a rehacer la conformación del Tribunal, merced a las vacantes que se fueron produciendo. ${ }^{313}$ De todos modos, como veremos enseguida, los republicanos en el Congreso distaban mucho de constituir un bloque unificado; estaban divididos, entre otras cuestiones, por la política agraria, y si bien tenían formalmente la mayoría, esta era muy ajustada.

\subsection{Los presidentes y el Congreso}

Harding, Coolidge y Hoover tuvieron la posibilidad de gobernar con un Congreso mayoritariamente controlado por su partido, sin embargo, su relación con la rama legislativa no fue de las mejores, probablemente debido a que ninguno de ellos tenía gran talento ni tacto para la política y tampoco eran figuras influyentes dentro de su partido. Harding, oriundo de Ohio, había sido vicegobernador de su estado (1903-1905) y luego senador nacional (1915-1921), donde integró el grupo liderado por Henry C. Lodge, que rechazó el Tratado de Versailles. Inicialmente intentó establecer una buena relación con el Senado y, para ello, en 1921 concurrió personalmente para obtener el acuerdo para la designación de sus ministros. ${ }^{314}$ Ese mismo año también fue al Senado para urgir la sanción una ley de presupuesto equilibrada, pero este gesto provocó resultados adversos en ambas cámaras; los senadores le reprocharon haber querido interferir con el proceso legislativo y los representantes se queja-

311 Desde el 66 Congreso (1919-1921) hasta el 71 Congreso (1929-1931), los republicanos tuvieron mayoría en ambas cámaras. Recién en el 72 Congreso (1931-1933) los demócratas recuperaron la mayoría en el House.

312 El ala conservadora de la Corte estuvo integrada por Willis Van Devanter (1911-1937), James C. McReynolds (1914-1941); William H. Taft (1921-1930), George Sutherland (1922-1938), Pierce Butler (1923-1939) y Edward T. Sanford (1923-1930). En la minoría liberal se encontraban Oliver W. Holmes (1902-1932), Louis Brandeis (1916-1932) y Harlan Fiske Stone (1925-1946).

313 Durante sus cuatro mandatos, F. D. Roosevelt llegó a nombrar a ocho nuevos jueces en la Corte Suprema, todos ellos adherentes al New Deal: Hugo Lafayette Black (1937-1971), Stanley Reed (19381957), Felix Frankfurter (1939-1962), William O. Douglas (1939-1975), Frank Murphy (1940-1949), James F. Byrnes (1941-1942), Robert H. Jackson (1941-1954) y Wiley B. Rutledge (1943-1949).

314 Recordemos que en la Constitución de los Estados Unidos (artículo II, sección 2, cláusula 2), a diferencia de la nuestra, los ministros del Poder Ejecutivo se designan con acuerdo del Senado. 
ron porque los money bills (proyectos de leyes de contenido financiero) debían iniciarse en el House. Aquejado por los numerosos escándalos de corrupción de sus ministros, falleció de un paro cardíaco en 1923 antes de completar su período presidencial. ${ }^{315} \mathrm{Su}$ sucesor, Coolidge, ejerció un liderazgo aún menor. Era un individuo retraído y de pocas palabras, cuya mayor virtud -pasiva, por cierto- fue ser un moralista de costumbres austeras en medio de un período de gran prosperidad económica, en el cual el establishment no reparaba en lujos y gastos. ${ }^{316}$ Tampoco logró establecer una buena relación con el Senado, al punto que, en 1925, fue rechazado el acuerdo para la designación de Charles Beecher Warren como ministro de Justicia (Attorney General), ${ }^{317}$ algo que no ocurría desde 1868. Por último, Hoover, que había llegado a la Casa Blanca precedido de una distinguida actuación durante la Primera Guerra Mundial a cargo de la Food Administración (Administración de los Alimentos) fue golpeado inmediatamente por la crisis económica de 1929, que no supo ni pudo manejar e impidió su reelección. ${ }^{318}$

\subsection{El Steering Committe Republicano en el House}

Cuando los republicanos en el 66 Congreso (1919-1921) recobraron la mayoría en el House, el candidato para ser elegido Speaker era James R. Mann, de Illinois, que había sido líder de la minoría desde 1911. Pero Mann no gozaba de la simpatía de muchos de sus colegas, pues había objetado algunos de sus proyectos y además se temía que, considerando a Cannon su mentor político y amigo personal, pretendiera seguir los pasos de este y centralizara el poder del Speaker. Fue por ello que el partido decidió proponer a Frederick H. Gillett, de Massachusetts, para presidir el House. Molesto por ello, Mann se rehusó a ser el líder de la mayoría, función que asumió entonces Frank W. Mondell, de Wyoming.

315 Uno de los escándalos más conocidos fue el llamado Teapot Dome, protagonizado por Albert Fall, su secretario de Interior, quien entregó reservas petroleras nacionales percibiendo por ello fuertes sumas de dinero. Fall fue enjuiciado por ello y sentenciado a 10 años de prisión. También fue acusado de corrupción Harry Daugherty, su Attorney General (ministro de Justicia), pero el juicio político en su contra no prosperó. En similares escándalos se vieron envueltos Charles Forbes, director de la Oficina de Veteranos (Veterans Bureau), y su asistente, Charles Cramer. Ver Mee (2014).

316 Ver Sobel (2015).

317 Warren había sido embajador en Japón (1921-1923) y luego en México (1924).

318 Paradójicamente, Hoover había anunciado durante la campaña presidencial que los Estados Unidos estaban más cerca de triunfar sobre la pobreza de lo que cualquier otro país había estado alguna vez ("We in America today are nearer to the final triumph over poverty than ever before in the history of any land”). Ver Singer, 1976, p. 31). 
Asimismo, para descentralizar aún más el poder dentro del House, el líder de la mayoría dejó de presidir, por primera vez, la Comisión de Presupuesto (Ways and Means) y fue creado un Steering Committe, ${ }^{319}$ compuesto por cinco miembros, que no estaba integrado ni por el Speaker ni por el presidente de la Comisión de Reglamento (Rules Committee). Dado que esta composición reducida levantó críticas acerca de la falta de representatividad de la comisión en el 67 Congreso (1921-1923), la cantidad de sus integrantes fue ampliada a ocho y fueron invitados a participar de sus reuniones el Speaker y el presidente de la Comisión de reglamento. Durante estos años, el Steering Committee se reunió casi a diario y fue el principal órgano de conducción del partido desde 1919 hasta 1925.

\subsection{La división interna de los republicanos}

Pese a la prosperidad económica reinante en la década de 1920, el sector agrícola pasaba por serias dificultades. Ello trajo como consecuencia una crisis interna dentro del Partido Republicano, que se dividió en dos bloques regionales. Los del este disfrutaban de la bonanza y los del oeste (los republicanos insurgentes o progresistas), asentados en las grandes llanuras (Great Plains) y en las montañas (Rocky Mountains), menos favorecidos, presionaban por obtener la sanción de leyes que les otorgaran ayuda. Si bien los primeros tenían el upper hand (ventaja) en el Congreso, los insurgentes, apoyados por los demócratas, bloqueaban muchas de las iniciativas de los regular republicans, pero no tenían fuerza suficiente para impulsar sus propias iniciativas.

Mientras los republicanos tuvieron amplia mayoría, tal como ocurrió en el 67 ${ }^{\circ}$ Congreso (1921-1923), ${ }^{320}$ ello no presentó mayores problemas y les permitió a individuos como Philip P. Campbell, de Kansas, controlar con mano férrea la Comisión de Reglamento, de la que era presidente. ${ }^{321}$ Pero esta división se hizo crítica en el 68 Congreso (1923-1925), en el que los republicanos retuvieron la

319 Tal como mencioné antes (ver nota 256), el Steering Committee es una comisión creada por cada partido para dirigir y controlar la marcha de los proyectos de ley. En el Senado ya existía desde el siglo anterior.

320 En el House, los republicanos tenían 302 representantes contra solo 131 de los demócratas.

321 En una oportunidad en la que Campbell se opuso a un proyecto que había obtenido mayoría en la comisión, le dijo a sus colegas que se podían ir al infierno, que la comisión era él y que en él residía todo el poder de obstruir los proyectos ("You can go to [hell] [...] it makes no difference what a majority of you decide; if it meets with my disapproval, it shall not be done; I am the Committee; in me repose absolute obstructive powers") (como se citó en Riddick, 1949, p. 123). 
mayoría en ambas cámaras, pero con un muy escaso margen sobre los demócratas. ${ }^{322}$ Ello dio lugar a una batalla por la integración de las comisiones y por la designación del Speaker. Los republicanos insurgentes, liderados por Robert La Follette, de Wisconsin, junto con los dos senadores de Minnesota pertenecientes al Farmer-Labor Party, aceptaron integrar las comisiones, pero sin participar del caucus republicano. Munido de esta ventaja, La Follete intentó remover a Albert Cummins, de Iowa, de la Comisión de Comercio Interestatal (Interstate Commerce Commission), y luego de 32 votaciones empatadas los republicanos regulares apoyaron al demócrata Ellison C. Smith, de South Carolina, que resultó elegido pese a que pertenecía a la minoría. También fue ardua la elección del Speaker. En 1923 compitieron Frederick H. Gillett, por los republicanos regulares, ${ }^{323}$ Henry A. Cooper, de Wisconsin, por los republicanos progresistas, y Finis J. Garrett, de Tennessee, por los demócratas. Luego de ocho votaciones empatadas entre Gillett y Garrett, los republicanos progresistas fueron convencidos por Nicholas Longworth, de Ohio, para que votaran por Gillett con la promesa de flexibilizar las reglas de debate. ${ }^{324}$

Al año siguiente, en 1924, La Follette volvió a poner en crisis a los republicanos al presentarse como candidato presidencial independiente por el Progressive Party, un partido recién fundado con el apoyo de grupos sindicales y socialistas. ${ }^{325}$ Compitió con Calvin Coolidge y con el candidato demócrata, John W. Davis, pero obtuvo tan solo el 16\% de los votos. Coolidge triunfó ampliamente $^{326} \mathrm{y}$, en el 690 Congreso (1925-1927), en el que los republicanos recuperaron en el House 25 bancas, ${ }^{327}$ los insurgentes no fueron invitados a integrar ninguna comisión, ${ }^{328}$ especialmente porque se negaron a votar por $\mathrm{Ni}$ -

322 En el Senado, los republicanos contaban con el 54,2\%; y los demócratas, con el 43,8\%. El 2\% restante lo tenía el recientemente creado Farmer-Labor Party, que subsistió como partido independiente hasta la década de 1940, cuando fue absorbido por los demócratas. En el House, los republicanos tenían el 51,3\%; los demócratas, el 48\%; el Farmer-Labor, el 0,5\%; y los socialistas (Socialist Party of America), el 0,2\%.

323 Recordemos que había sido elegido Speaker en el 66 Congreso (1919-1921) y reelegido en el 67 Congreso (1921-1923).

324 En particular modificaron la llamada Rule of Discharge (regla de dispensa), aprobada inicialmente en 1910, reduciendo de 218 a 150 el número de votos necesarios para que la ley pudiera ser tratada en el recinto, aun habiendo sido rechazada en comisión.

325 Ver Thelen (1976b, en especial caps. viii y ix).

326 En votos populares obtuvo el 54\% y en el colegio electoral ganó en todos los estados del norte, menos en Wisconsin, donde triunfó La Follette.

327 De 222 bancas en el $68^{\circ}$ Congreso pasaron a tener 247 en el $69^{\circ}$ Congreso, con una mayoría del 57\%.

328 Asimismo, John M. Nelson y Florian Lampert, ambos de Wisconsin, fueron desplazados de la 
cholas Longworth como Speaker, apoyando en cambio a Henry A. Cooper, de Wisconsin. ${ }^{329}$ Siguiendo el ejemplo de Reed y Cannon, Longworth rápidamente inició la tarea de centralizar el poder del Speaker, lo que puso en práctica entre 1925 y 1931 con la ayuda de John Q. Tilson, de Connecticut, líder de la mayoría, y de Bertrand H. Snell, de New York, presidente de la Comisión de Reglamento (Rules Committe).

Hacia el final de este período, cuando los republicanos estaban más debilitados, la separación entre ambas líneas internas se hizo más crítica. En el 72。 Congreso (1931-1933), Herbert Hoover, sucesor de Coolidge, tuvo que lidiar con un House donde los republicanos insurgentes se aliaban con los demócratas, que habían recuperado la mayoría, ${ }^{330}$ y con un Senado casi empatado. ${ }^{331}$

\subsection{Escaso uso y poca efectividad de la Cloture Rule}

Durante este período, la Regla de Cierre o Clausura (Cloture Rule), adoptada por el Senado en 1917 para impedir el filibuster, fue poco utilizada y, cuando se la intentó emplear, tuvo poca efectividad. Fue invocada en once oportunidades (cinco de ellas en 1927) y solo resultó efectiva en cuatro de ellas. Pudo ser aplicada con éxito en 1919, cuando se votó el rechazo del Tratado de Versailles; en 1926, con motivo del tratamiento de un protocolo de la Corte Permanente de Justicia Internacional (World Court), creada por el Tratado de Versailles, a la que finalmente los Estados Unidos nunca adhirieron; y en dos oportunidades

presidencia de las comisiones de elecciones y de patentes, respectivamente.

329 Además de asegurarse su posición en las comisiones, los republicanos regulares se garantizaron que las leyes no aprobadas en comisión no pudieran ser llevadas fácilmente al recinto. Para ello, modificaron nuevamente la llamada Rule of Discharge, elevando otra vez de 150 a 218 el número de votos necesarios para poder tratar la ley en el recinto, luego de su rechazo en comisión.

330 Si bien los republicanos comenzaron este Congreso con una escasa mayoría de 217 representantes sobre 216 de los demócratas, ya en el final, merced a elecciones intermedias, la habían perdido. En 1933, al concluir el 72 Congreso, los demócratas tenían en el House 220 bancas, los republicanos 206, los Farmer-Labor 1 y había 8 bancas vacantes.

331 En el Senado, la mayoría republicana era ínfima. Sobre un total de 96 senadores, los republicanos tenían 48, los demócratas 46, los Farmer-Labor 1 y había 1 banca vacante. Con gran ingenuidad política, Hoover le pidió al senador republicano James Watson, de Indiana, líder de la mayoría republicana, que le permitiera a los demócratas tomar el control de las comisiones para concluir con todas las demoras y convertir ese sabotaje en un acto responsable (to convert their sabotage into responsibility) para poder trabajar más productivamente y no hacer demagogia con cada propuesta del presidente ("[to] deal more constructively with the Democratic leaders if they held full responsibility in both houses, than with an opposition in the Senate conspiring in the cloakrooms to use every proposal of mine for demagoguery"). Watson y sus colegas se negaron, por supuesto, pues no estaban dispuestos a entregarles el control de las comisiones a los demócratas. Ver Jones (1970, p. 144). 
en 1927, una de ellas con motivo de una ley que, entre otros aspectos, afectaba a los bancos que no eran miembros del sistema de la Reserva Federal ${ }^{332}$ y la otra sobre regulaciones de la llamada Prohibition (Ley Seca), establecida por la Enmienda XVIII.

Hubo también filibusters en casos tan sensibles y conflictivos por aquel entonces que se decidió no emplearla. En 1922, un grupo de senadores sureños montó un filibuster contra una ley que prohibía los linchamientos. Entre sus protagonistas se hallaba el poderoso senador demócrata Oscar Underwood, de Alabama, ${ }^{33}$ quien se encargó de dejar muy en claro que el Senado no volvería a sesionar hasta que el proyecto fuera retirado. ${ }^{334}$ La promesa se cumplió y el Senado estuvo paralizado hasta que el proyecto fue retirado sin haberse recurrido al Cloture Rule. ${ }^{335}$ Una actitud similar tuvo lugar en 1927, cuando se quiso poner fin al filibuster motivado por el proyecto de prolongar la tarea de la comisión presidida por el senador demócrata James A. Reed, de Missouri, que investigaba la presunta corrupción habida en la campaña de los senadores republicanos Frank L. Smith, de Illinois, y William S. Vare, de Pennsylvania. Si bien la iniciativa contaba con mayoría, un reducido grupo de senadores obstruyó el proyecto y la Cloture Rule no fue empleada. ${ }^{336}$

\subsection{El voto femenino. La Enmienda XIX}

Uno de los acontecimientos más importantes de este período tuvo lugar en marzo de 1919, cuando el Congreso sancionó la Enmienda XIX, ratificada poco

332 McFadden Act of 1927.

333 Recordemos que ya había liderado el House en años anteriores.

334 "It is perfectly apparent that you are not going to get an agreement to vote on [this bill] [...] I want to say right now to the Senate that if the majority party insist on this procedure they are not going to pass the bill, and they are not going to do any other business [...] [W] e are going to transact no other business until we have an understanding about this bill [...]We are willing to take the responsibility, and we are going to do it" Vid. Haynes (1938, p. 411).

335 Molesto con esta actitud, el senador Charles Curtis, de Kansas, jefe del bloque republicano, le pidió a Calvin Coolidge, por entonces presidente del Senado (era vicepresidente de Harding), que aplicara las Reed Rules, creadas por Thomas B. Reed como Speaker del House en el siglo anterior, pero Coolidge declinó hacerlo.

336 Cuando Calvin Coolidge fue electo presidente, en 1925, su vicepresidente, Charles G. Dawes, quien lejos de ser un aliado fue un opositor de Coolidge, denunció estas irregularidades y llevó a cabo una campaña nacional para imponer nuevas reglas que impidieran el filibuster. Sorpresivamente, se encontró con la oposición de la American Federation of Labor (AFL), en cuya opinión, la iniciativa de Dawes emanaba de las cámaras secretas de los intereses depredadores ("emanates fron the secret chambers of the predatory interests"). 
más de un año después, en agosto de 1920, por medio de la cual se les acordó el derecho de sufragio a las mujeres. ${ }^{337}$ La sanción de esta Enmienda fue la consagración de una prolongada lucha por extender el sufragio a todo el electorado y no solamente a unos pocos ciudadanos varones, que se inició prácticamente con la Independencia. ${ }^{338}$ En el ínterin, mujeres como Susan B. Anthony (18871922), coeditora de un extenso trabajo sobre la historia del sufragio femenino, fueron arrestadas y multadas por intentar ejercer su derecho. También fueron activas "sufragistas" Alice S. Paul, Lucy Burns ${ }^{339}$ y Carrie Chapman Catt. ${ }^{340}$

Antes de la Enmienda XIX, varias legislaturas estatales ya habían establecido el derecho al sufragio femenino. Wyoming les concedió a las mujeres el derecho de votar por funcionarios territoriales en 1869 y lo mantuvo en 1890, cuando el territorio fue convertido en estado. Colorado siguió este ejemplo en 1893, Utah en 1895 e Idaho en 1896. En 1914, once estados ya permitían el sufragio igualitario, y en 1917 las sufragistas triunfaron en New York, que era considerado un reducto opositor del este. Estas victorias fortificaron el movimiento nacional contra el cual se oponía, como argumento, que la legislación electoral debía ser decidida por cada estado sin interferencia del Gobierno federal. No obstante, en la elección de 1916 las plataformas de los dos partidos defendieron el sufragio femenino en contra de la opinión de Woodrow Wilson, cuya oposición desató una ola de violentas protestas, similares a las que estaban teniendo lugar también en el Reino Unido. A partir de allí, las cosas se precipitaron. En septiembre de 1917, la comisión del Senado para el sufragio femenino elevó un

337 El texto de la enmienda es el siguiente: "1. El derecho de sufragio de los ciudadanos de los Estados Unidos no será desconocido ni limitado por los Estados Unidos o por Estado alguno por razón de sexo. 2. El Congreso estará facultado para hacer cumplir este artículo por medio de leyes apropiadas" " 1 . The right of the citizens of the United States to vote shall not be denied or abridged by the United States or by any State on account of sex. 2. Congress shall have power to enforce this article by appropriate legislation").

338 Las condiciones religiosas para votar fueron abolidas gradualmente, al igual que las fundadas en el derecho de propiedad. Fueron eliminadas luego las de la raza y finalmente llegó el turno de las del sexo. Estas últimas podrían haber sido extirpadas cuando la Enmienda XV extendió el voto a los afroamericanos, pero no fue así. Los propagandistas del sufragio femenino intentaron en ese momento que el sexo fuera incluido entre los requisitos de raza y color, pero fracasaron. A partir de entonces comenzaron una campaña para incorporar tal requisito y lograron que la cuestión fuera introducida en el Senado en 1878 y reintroducida sesión por sesión hasta que fue ratificada la Enmienda XIX.

339 Juntas crearon, en 1916, el Partido Nacional de la Mujer (National Woman's Party), disuelto en 1930. Ambas integraron también el grupo de las llamadas Centinelas Silenciosas (Silent Sentinels), que acamparon frente a la Casa Blanca durante dos años -de 1917 a 1919- en demanda del voto femenino.

340 Fue presidenta de la National American Woman Suffrage Association y fundadora de la League of Women Voters y de la International Alliance of Women. 
informe favorable a la enmienda y, dos meses después, la comisión de justicia de la Cámara de Diputados emitió su auspicio. Wilson entendió que debía cambiar su posición y anunció su apoyo a la enmienda. Señaló que los ingleses estaban otorgando el voto femenino y que estaban reconociendo los patrióticos servicios de la mujer en la guerra, de modo que los Estados Unidos no podían hacer menos que seguir su ejemplo. Poco más tarde, en las elecciones de noviembre de 1918, tres estados más emanciparon por entero a la mujer y un número adicional de defensores del sufragio femenino fue elegido para el Senado y la Cámara de Representantes con el propósito de asegurar un exitoso final para la enmienda. Asimismo, en su mensaje anual al Congreso del 2 de diciembre de 1918, Wilson alegó que el mejor tributo que se les podía rendir a las mujeres era igualarlas a los hombres en cuanto a derechos políticos, ya que se habían mostrado iguales en todo cuanto habían encarado.

\subsection{Las dos primeras senadoras}

Acompañando la igualdad de hombres y mujeres ante el sufragio, se produjo en 1922 el ingreso de la primera senadora en el Congreso, aunque no creo que el caso de Rebecca Latimer Felton pueda computarse exactamente como un triunfo cabal de las sufragistas, pese a que era una antigua militante de ese movimiento. Su ingreso como senadora, cuando ya había cumplido 87 años -cargo que ocupó solo por un día- fue en, todo caso, parte de una estrategia electoral para beneficiar la candidatura de Thomas W. Hardwick.

En las elecciones para senadores de 1922, el candidato por Georgia era Hardwick, por entonces gobernador del estado, cuando el senador Thomas E. Watson, también de Georgia, murió inesperadamente. Para cubrir temporalmente esa vacante hasta el final del mandato de Watson, Hardwick eligió a Rebecca Felton, quien no competía en la elección y le permitía, además, granjearse el voto femenino. ${ }^{341}$ Asimismo, no se esperaba que el Congreso volviera a reunirse hasta después de las elecciones, de modo tal que era improbable que Felton prestara efectivamente juramento y ocupara la banca, siquiera por escasos días. La elección, sin embargo, no la ganó Hardwick, sino Walter F. George, quien, presionado por una campaña emprendida por las mujeres blancas de Georgia, en lugar de tomar posesión de su cargo en la siguiente reunión del Senado, permitió que Felton prestara juramento. De esta manera, ella se con-

341 Hardwick pretendía compensar con ello su oposición a la Enmienda XIX. 
virtió en la primera senadora -por un solo día- y la única mujer que ocuparía una banca en el Senado por Georgia por espacio de casi un siglo. ${ }^{342}$

La segunda senadora fue Hattie Ophelia Caraway, demócrata de Arkansas, elegida en 1932. También llegó al senado para ocupar temporalmente una vacante, en este caso, la de su marido, Thaddeus Horatius Caraway, fallecido en noviembre de 1931 durante el 72॰ Congreso (1931-1933). No obstante, a diferencia de su predecesora, no solo completó el mandato de su marido hasta 1933, sino que en 1932 fue electa para un período completo (1933-1939) y reelecta en 1938 para un segundo período (1939-1945). En la elección de 1944 compitió por un tercer período (1945-1951), pero fue vencida por J. William Fulbright. Caraway llevó adelante una intensa actividad apoyando el New Deal de Franklin D. Roosevelt y fue la primera mujer en presidir una comisión legislativa. ${ }^{343}$ Durante sus trece años como senadora, otras tres mujeres fueron senadoras también ${ }^{344}$

\subsection{La Corte Suprema fortifica el poder de las comisiones legislativas de investigación}

En 1922, bajo el Gobierno de Harding, estalló el llamado escándalo del Tea Pot Dome, producido como consecuencia de concesiones petroleras otorgadas por Albert B. Fall, secretario del Interior, a muy bajo precio y sin licitación pública en terrenos bajo jurisdicción de la Marina. ${ }^{345}$ Una de ellas estaba ubicada en la zona de Tea Pot Dome, Wyoming, y le fue otorgada a Mammoth Oil, una subsidiaria de la Sinclair Oil Corporation; las otras áreas, Elk Hills y Buena

342 Hasta 2020, el estado de Georgia no volvió a ser representado por una mujer senadora y nuevamente, en este caso, sucedió algo similar a lo ocurrido un siglo atrás. En 2020, durante el 116 ${ }^{\circ}$ Congreso (2019-2020), el senador republicano John Hardy Isakson renunció por razones de salud y el gobernador de Georgia, Brian Kemp, eligió para reemplazarlo a Kelly Lynn Loeffler, una ferviente republicana y católica, firme sostenedora de Donald Trump. Luego de completar el mandato, Loeffler intentó ser reelecta para el $117^{\circ}$ Congreso (2021-2023), pero fue vencida por el demócrata Raphael G. Warnock, afroamericano y pastor protestante.

343 Ver Hendricks (2013).

344 Ellas fueron: Rose McConnell Long, demócrata de Louisiana, Dixie Bibb Graves, demócrata de Alabama, y Gladys Pyle, republicana de South Dakota. La primera fue elegida en 1935 para completar el mandato de su marido, Huey Long, un político populista conocido como el Kingfish, que fue asesinado. La segunda fue elegida en 1937 por su propio marido, Bibb Graves, el gobernador de Alabama, para completar el mandato de Hugo Black, que había sido designado juez de la Corte Suprema. Y la tercera llegó al Senado por sus propios medios no para completar el mandato de otro senador, sino luego de ser electa en 1938 para ejercer un período completo (1939-1945), aunque renunció antes de haber cumplido el primer año.

345 Ver McCartney (2009). 
Vista Oil Fields, estaban en California y les fueron otorgadas a la Pan American Petroleum and Transport Company. La investigación del caso en el Senado, impulsada por el senador demócrata Thomas J. Walsh, de Montana, pudo probar finalmente, luego de varias dificultades, que Fall había recibido dinero a cambio del otorgamiento de las concesiones. ${ }^{346}$ En el curso de la investigación, Harry M. Daugherty, el Attorney General, intentó encubrir a Fall, y cuando su hermano, Mally Daugherty, se negó a testificar ante la comisión investigadora, fue ordenado su arresto. Daugherty interpuso un hábeas corpus que fue rechazado por la Corte Suprema en McGrain v. Daugherty, ${ }^{347}$ sosteniendo que el poder de investigar es una facultad implícita del Congreso, el cual debe contar con los medios necesarios para ser puesto en práctica. ${ }^{348}$ Dos años después, en Sinclair v. United States, ${ }^{349}$ otro caso vinculado también con el mismo escándalo, ${ }^{350}$ la Corte sostuvo que un testigo podía ser condenado por incurrir en falso testimonio (perjury) ante una comisión legislativa.

\subsection{La reorganización de las comisiones en el Senado}

Desde mediados del siglo XIX en adelante, la cantidad de comisiones permanentes (standing committees) en el Senado no había parado de crecer. Eran 25 en 1853, habían aumentado a 42 en 1889 y en el cuarto de siglo siguiente esa cifra continuó en ascenso. ${ }^{351}$ En 1884, 5 comisiones temporarias (select committees) se habían hecho permanentes, 3 más se habían agregado en 1896; en 1909 todas las comisiones temporarias fueron transformadas en permanentes y se crearon 9 más, a las que se les agregaron otras 3 en 1913. Como resultado de ello, hacia 1914 existían unas 74 comisiones permanentes, un número muy superior al de los senadores que integraban la mayoría. Prácticamente todos los senadores, aun

346 Fall fue penalmente enjuiciado y cumplió un año en prisión, convirtiéndose en el primer miembro del gabinete presidencial en correr esa suerte.

347273 U.S. 135 (1927).

348 " [...] the two houses of Congress, in their separate relations, possess not only such powers as are expressly granted to them by the Constitution, but such auxiliary powers as are necessary and appropriate to make the express powers effective, and the other that neither house is invested with "general" power to inquire into private affairs and compel disclosures [...] We are of opinion that the power of inquiry -with process to enforce it - is an essential and appropriate auxiliary to the legislative function" (273 U.S. en pp. 173 y 174).

349279 U.S. 263 (1929).

350 Harry Ford Sinclair, ejecutivo de la Sinclair Oil Corporation, era quien le había pagado a Fall por el otorgamiento de la concesión en California.

351 Ver Kravitz (1974, pp. 27-38). 
los recién incorporados, tenían la posibilidad de integrar una comisión y muchos de ellos podían aspirar a presidirlas, aun estando en la minoría. ${ }^{352}$ Una gran cantidad de ellas eran consideradas sinecure committees, es decir, no cumplían ninguna función legislativa específica, salvo la de proveer un espacio de trabajo y servicios a los senadores, ${ }^{353}$ en una época en la que el Senado no disponía todavía de espacio suficiente para sus oficinas administrativas. ${ }^{354}$ En 1920, cuando se tomó la decisión de reducir la cantidad de comisiones, el número de estas había llegado a 80 , algunas de las cuales era evidente que no tenía sentido alguno mantener. ${ }^{355} \mathrm{Se}$ decidió entonces eliminar 42 comisiones obsoletas, y en el 68 Congreso (19231925) el número total de comisiones permanentes ya estaba reducido a $34 .{ }^{356}$

\subsection{El nuevo régimen presupuestario}

Hasta 1920, el Gobierno federal no tenía un sistema centralizado para elaborar la ley de presupuesto. Cada departamento (ministerio) elaboraba su propio presupuesto y lo enviaba individualmente al House, como cámara de origen, donde intervenían unas ocho comisiones diferentes que analizaban estos proyectos de ley según su propia competencia. Algo similar ocurría en el Senado. El resultado era que no se sancionaba una ley de presupuesto unificada, sino muchas leyes diferentes y, en algunos casos, había más de una por cada departamento. Como

352 Al comenzar el 60 Congreso (1907-1909), el Partido Republicano, en mayoría, se asignó la presidencia de 61 comisiones y le otorgó 10 a los demócratas.

353 El senador La Follette recordaba que cuando fue designado presidente de la Comisión para Investigar el Estado la Rivera del río Potomac en Washington (Committee to Investigate the Condition of the Potomac River Front at Washington) descubrió que la comisión no se había reunido nunca ni se había presentado proyecto de ley alguno para ordenar la limpieza del río. Ver: https://www.senate. gov/artandhistory/history/minute/Senate_Eliminates_42_Committees.htm.

354 En 1908 fue construido el Russell Senate Office Building, primer edificio de oficinas del Senado. Luego fueron construidos dos más: el Dirksen Senate Office Building, en 1958, y el Hart Senate Office Building, en 1982.

355 Existía todavía la comisión de los reclamos de la Guerra de la Independencia (Revolutionary War), pese a que esta había concluido hacía ya 137 años.

356 En orden alfabético, estas comisiones eran las siguientes: Agriculture and Forestry; Appropriations; Audit and Control the Contingent Expenses of the Senate; Banking and Currency; Civil Service; Claims; Commerce; District of Columbia; Education and Labor; Enrolled Bills; Expenditures in Executive Departments; Finance; Foreign Relations; Immigration; Indian Affairs; Interoceanic Canals; Interstate Commerce; Irrigation and Reclamation; Judiciary; Library; Manufactures; Military Affairs; Mines and Mining; Naval Affairs; Patents; Pensions; Post Office and Post Roads; Printing; Privileges and Elections; Public Buildings and Grounds; Public Lands and Surveys; Rules y Territories and Insular Possessions. Había, a su vez, cinco select committees: Alien Property Custodian's Office; Internal Revenue Bureau; Senatorial Elections; Tariff Commission y War Finance Corporation Loans. 
tal, el sistema presupuestario existente era bastante caótico y generaba críticas. ${ }^{357}$ A fin de ordenar la cuestión, fue sancionada la Budget and Accounting Act of $1921,{ }^{358}$ que le ordenó al presidente centralizar la elaboración del presupuesto, especificando cómo y qué debía ser incluido en él disponiendo, asimismo, que el proyecto debía ser enviado al comienzo de cada sesión legislativas anual. ${ }^{359}$ La ley creó también la Oficina de Presupuesto en jurisdicción del Departamento el Tesoro (Ministerio de Economía) ${ }^{360}$ y la General Accounting Office, ${ }^{361}$ a cuyo cargo fue puesto el Comptroller General. ${ }^{362}$

357 Alvan T. Fuller, representante republicano de Massachusetts y luego gobernador de ese estado, decía en 1918 que no se les podia exigir a los empresarios que economizaran y fueran eficientes cuando el Congreso era costoso e ineficiente ("The President is asking our business men to economize and become more efficient while we continue to be the most inefficient and expensive barnacle that ever attached itself to the ship of state"). Ver Hasbrouck (1972, p. 15).

35842 Statutes at Large 20.

359 "Section 201. The President shall transmit to Congress on the first day of each regular session, the Budget, which shall set forth in summary and in detail : (a) Estimates of the expenditures and appropriations necessary in his judgment for the support of the Government for the ensuing fiscal year; except that the estimates for such year for the Legislative Branch of the Government and the Supreme Court of the United States shall be transmitted to the President on or before October 15th of each year, and shall be included by him in the Budget without revision; (b) His estimates of the receipts of the Government during the ensuing fiscal year, under (1) laws existing at the time the Budget is transmitted and also (2) under the revenue proposals, if any, contained in the Budget; (c) The expenditures and receipts of the Government during the last completed fiscal year; (d )Estimates of the expenditures and receipts of the Government during the fiscal year in progress; (e) The amount of annual, permanent, or other appropriations, including balances of appropriations for prior fiscal years, available for expenditure during the fiscal year in progress, as of November 1 of such year; (f) Balanced statements of (1) the condition of the Treasury at the end of the last completed fiscal year, (2) the estimated condition of the Treasury at the end of the fiscal year in progress, and (3) the estimated condition of the Treasury at the end of the ensuing fiscal year if the financial proposals contained in the Budget are adopted; (g) All essential facts regarding the bonded and other indebtedness of the Government; and (h) Such other financial statements and data as in his opinion are necessary or desirable in order to make known in all practicable detail the financial condition of the Government".

360 "Section 207. There is hereby created in the Treasury Department a Bureau to be known as the Bureau of the Budget. There shall be in the Bureau a Director and an Assistant Director, who shall be appointed by the President and receive salaries of $\$ 10,000$ and $\$ 7,500$ a year, respectively. The Assistant Director shall perform such duties as the Director may designate, and during the absence or incapacity of the Director or during a vacancy in the office of Director he shall act as Director. The Bureau, under such rules and regulations as the President may prescribe, shall prepare for him the Budget, the alternative Budget, and any supplemental or deficiency estimates, and to this end shall have authority to assemble, correlate, revise, reduce, or increase the estimates of the several departments or establishments".

361 "Section 301. There is created an establishment of the Government to be known as the General Accounting Office, which shall be independent of the executive departments and under the control and direction of the Comptroller General of the United States. The offices of Comptroller of the Treasury and Assistant Comptroller of the Treasury are abolished, to take effect July 1, 1921 [...]".

362 "Section 302. There shall be in the General Accounting Office a Comptroller General of the Unit- 


\subsection{El debate sobre el aumento y redistribución de las bancas en el House. La Permanent Apportionment Act of 1929}

Un debate arduo, que se extendió a lo largo de toda la década de 1920, fue el aumento y la redistribución (reapportionment) de las bancas en el House luego de cada censo. Tal como vimos anteriormente, la Apportionment Act of 1911, siguiendo los resultados del Censo de 1910, estableció que el número de representantes aumentaría de 391 a 435. Hasta ese momento, salvo en 1880, ningún estado había perdido una banca en el House ${ }^{363}$ pues luego de cada censo el número de representantes aumentaba proporcionalmente, precisamente para que ningún estado se viera privado de las bancas que ya poseía. ${ }^{364}$ Esta cuestión volvió a plantearse cuando el 14 Censo, llevado a cabo en 1920, puso de manifiesto que la población no solo había aumentado, sino que una buena cantidad de habitantes había migrado de las zonas rurales a los centros urbanos. Esto obligaba a tomar la decisión de continuar incrementando indefinidamente el número de representantes, o bien de congelarlo en 435 o en algún otro número. Si se decidía lo primero, la cantidad de bancas en esa oportunidad se elevaría a unas 483, por el contrario, si se mantenía su número en 435, 11 estados perderían bancas, las cuales serían redistribuidas en 8 de ellos.

Para evitar esta segunda solución, políticamente conflictiva, a comienzos de 1921, cuando estaba por terminar el 66 Congreso (1919-1921), la Comisión de Censo propuso aumentar los representantes a 483, beneficiando con ello a 25 estados a los cuales se les adjudicaban las nuevas bancas. La propuesta, sin embargo, fue rechazada en el House por una mayoría de 267-76. ${ }^{365}$ En su reemplazo, se dio media sanción a un proyecto que mantenía la cantidad de representantes en los 435 establecidos en 1911, pero se los redistribuía conforme el aumento y la migración poblacional registrada por el Censo de $1920 .^{366}$ Sin embargo, en marzo de 1921, al finalizar el 66 Congreso, el Senado no había aprobado aún esta modificación. Al mes siguiente, cuando se inició el 67 Congreso, la Comisión de Censo del House aprobó un nuevo proyecto,

ed States and an Assistant Comptroller appointed General of the United States, who shall be appointed by the President with the advice and consent of the Senate, and shall receive salaries [...]".

363 Únicamente Maine y New Hampshire habían perdido -una banca cada uno- en 1880.

364 Antes de ello, luego del Censo de 1890, el House había aumentado de 357 a 391.

365 Los argumentos para no aumentar el número de representantes fueron de dos órdenes. En primer lugar, se dijo que una cámara muy numerosa dificultaba los debates. Por el otro lado, se hizo pesar el costo económico de tener que modificar el tamaño del recinto.

366 Se restaban doce bancas a once estados y se las redistribuía entre aquellos que habían tenido mayor aumento poblacional. 
elevando a 460 el número de representantes ${ }^{367}$ pero en el pleno esta propuesta fue rechazada por una mayoría de 146-142 y la cuestión no volvió a ser tratada.

Hacia 1925, el problema no había sido resuelto y ya era claro, por entonces, que la migración de la población de las áreas rurales a las urbanas no había sido un fenómeno meramente temporario producido por la guerra, sino que se trataba de una redistribución permanente. Como resultado de este cambio, ciudades como Los Ángeles y Detroit, cuya población había aumentado sensiblemente, reclamaban una mayor representación. Todo ello generó un debate en el House acerca de si era constitucionalmente obligatorio o no redistribuir las bancas luego de cada Censo. La cuestión fue sometida a votación y, por mayoría de 265-87, se decidió que no lo era. ${ }^{368}$

A pesar de ello, en enero de 1927, Calvin Coolidge insistió en que era necesario sancionar una ley de redistribución de las bancas en el House. Si bien la Comisión de Censo rechazó esta petición, el presidente de la comisión, Edward Hart Fenn, republicano de Connecticut, intentó el 2 de marzo de 1927, un día antes de que concluyera el 69० Congreso (1925-1927), que se aprobara un proyecto de ley de su autoría, autorizando al secretario de Comercio a redistribuir las bancas sobre la base del Censo de 1930. En esa oportunidad, la propuesta fue rechazada por 197-183 votos. Reunido el 70 Congreso (1927-1929), el proyecto de Fenn -con modificaciones- fue sometido nuevamente a votación. Por 186-165 votos, se resolvió enviarlo a comisión y -con nuevas modificaciones- fue aprobado por voto cantado (voice vote) en enero de 1929, casi al final de dicho Congreso. Sin embargo, al mes siguiente, cuando debía ser tratado en el Senado, fue abandonado por sus propios promotores ante un filibuster, que amenazaron con llevar a cabo los senadores de los estados que perderían bancas en el House.

Cuando se reunió el 71 Congreso (1929-1931), habían pasado ya casi diez años desde el Censo de 1920 sin que la composición del House se modificara en función de los cambios poblaciones registrados por dicho censo, de modo tal que era acuciante darle una solución al problema. Herbert Hoover, que por

367 Ello implicaba que Maine y Missouri perdían una banca cada uno.

368 El problema fue planteado en abril de 1926 por Henry E. Barbour, representante republicano de California, en cuya opinión la distribución de las bancas luego de cada censo era constitucionalmente obligatoria. La posición contraria fue sostenida por Bertrand H. Snell, republicano de New York y presidente de la Comisión de Reglamento. Por su lado, Nicholas Longworth, el Speaker, a pesar de que tres de sus predecesores -Joseph W. Kiefer (1881-1883), Thomas B. Reed (1889-1891 y 1895-1899) y David B. Henderson (1899-1903)- habían aplicado la tesis de Barbour, sostuvo que esta era incorrecta y sometió el diferendo a votación. Por una mayoría de 265 a 87, el House decidió por la negativa. 
entonces se estrenaba como presidente, llamó a una sesión especial en abril de 1929 para ponerle fin a este largo conflicto y, en esa oportunidad, ambas cámaras actuaron muy velozmente, sancionando con escasos días de diferencia entre una y otra ${ }^{369}$ la llamada Permanent Apportionment Act of 1929, ${ }^{370}$ que, con las leves modificaciones introducidas en $1940,{ }^{371} 1941^{372}$ y $1996,{ }^{373}$ se mantiene vigente hasta el presente. ${ }^{374}$

Como toda ley que intenta resolver un problema difícil, su texto -bastante oscuro en la parte más importante- es el reflejo de este conflicto. Sus primeros 21 artículos están dedicados a la regulación del censo y recién en el artículo (sección) 22 aparece la cuestión de la composición del House. A este fin, el artículo 22(a) dispuso que, dentro de la primera semana después de concluida la segunda sesión regular del 71 ${ }^{\circ}$ Congreso (1929-1931), ${ }^{375}$ y en cada uno de los cinco congresos siguientes, ${ }^{376}$ el presidente debía informarle al Congreso el número de personas existentes en cada estado ${ }^{377}$ de acuerdo con los resultados del $15^{\circ}$ Censo, ${ }^{378} \mathrm{y}$ de los censos siguientes y de la cantidad de representantes a los que cada estado tuviera derecho, bajo la distribución por entonces existente, ${ }^{379}$ conforme el método que se describía en los incisos siguientes. ${ }^{380}$

Puede verse que esta ley mantuvo en 435 la cantidad de bancas establecida en 1911 sin imponer expresamente que esa cifra debía ser mantenida más allá de 1940, ${ }^{381}$ cuando se llevara a cabo el 16 Censo. Asimismo, estableció en forma

369 En el House fue aprobada el 11 de junio; y en el Senado, el 13 de junio. Hoover la promulgó el 18 de junio.

37046 Status at Large 21.

37154 Status at Large 162.

37255 Statutes at Large 761.

373110 Statutes at Large 1724.

3742 USC § 2 (a).

375 Es decir, a partir de diciembre de 1930.

376 Es decir, hasta la realización del siguiente censo, que tendría lugar en 1940.

377 Quedaban excluidos los indígenas no gravados con impuestos (indians not taxed).

378 Es decir, el Censo de 1930.

379 Es decir, la efectuada por la Ley de 1911.

380 "Section 22(a). On the first day, or within one week thereafter, of the second regular session of the Seventy-first Congress and of each fifth Congress thereafter, the President shall transmit to the Congress a statement showing the whole number of persons in each State, excluding Indians not taxed, as ascertained under the fifteenth and each subsequent decennial census of the population, and the number of Representatives to which each State would be entitled under an apportionment of the then existing number of Representatives made in each of the following manners: [...]".

381 De hecho, se ha mantenido en 435 hasta la actualidad. 
permanente el modo en el que esas bancas se distribuirían automáticamente de allí en adelante, cuidando que todos los estados, sin perjuicio de su población, tuvieran al menos un representante. Para llevar a cabo el reapportionment, la ley preveía tres métodos: (a) el empleado en el último censo; ${ }^{382}$ (b) el de las fracciones mayores; ${ }^{383}$ y (c) el de la igual proporción (equal proportion). ${ }^{384}$ Este último fue el adoptado finalmente en 1941 y es el que rige en la actualidad. ${ }^{385}$ Como resultado de la aplicación de esta ley, en el 73º Congreso (1933-1935), cuyos representantes fueron elegidos en 1932, se produjeron fuertes cambios en la composición del House. ${ }^{386}$

\subsection{La Enmienda XX}

Ya sobre el final de este período, más exactamente el 23 de enero de 1933, fue ratificada la Enmienda XX, que modificó el artículo I, sección 4, cláusula 2 del texto original, poniendo fin a la prolongada extensión que tenían hasta entonces las llamadas lame duck sessions, ${ }^{387}$ es decir, aquellas en las cuales el Congreso continuaba sesionando con sus antiguos miembros, por espacio de cuatro meses, pese a que ya habían sido elegidos los nuevos legisladores.

Esta anomalía tenía una cierta explicación por razones históricas, pero se

382 "Section 2(a)(1) By apportioning the then existing number of Representatives among the several States according to the respective numbers of the several States as ascertained under such census, by the method used in the last preceding apportionment, no State to receive less than one Member".

383 "Section 2(a)(2) By apportioning the then existing number of Representatives among the several States according to the respective numbers of the several States as ascertained under such census, by the method known as the method of major fractions, no State to receive less than one Member".

384 "Section 2(a)(3) By apportioning the then existing number of Representatives among the several States according to the respective numbers of the several States as ascertained under such census, by the method known as the method of equal proportions, no State to receive less than one Member".

385 Conforme a 2 USC § 2(a): "On the first day, or within one week thereafter, of the first regular session of the Eighty second Congress and of each fifth Congress thereafter, the President shall transmit to the Congress a statement showing the whole number of persons in each State, excluding Indians not taxed, as ascertained under the seventeenth and each subsequent decennial census of the population, and the number of Representatives to which each State would be entitled under an apportionment of the then existing number of Representatives by the method known as the method of equal proportions, no State to receive less than one Member".

386 Los cambios fueron los siguientes: 21 estados perdieron en total 27 bancas. De ellos, el más perjudicado fue Missouri, que perdió 3; Georgia, Iowa, Kentucky y Pennsylvania perdieron 2 cada uno. Entre los estados más beneficiados, el gran ganador fue California, que obtuvo 9 bancas adicionales, duplicando prácticamente su número (tenía 11 y llegó a 20), seguido de Michigan con 4, Texas con 3 y New Jersey y New York con 2 cada uno.

387 La expresión lame duck (literalmente, "pato rengo"), se aplica usualmente a aquellas personas que han perdido el poder. 
había convertido en un abuso por parte de aquellos legisladores que no eran reelegidos. Bajo la cláusula constitucional antes mencionada, el Congreso debía reunirse, al menos una vez al año, el primer lunes del mes de diciembre. ${ }^{388}$ Ahora bien, dado que el 1 ${ }^{\circ}$ Congreso (1789-1791) se reunió por primera vez el 4 de marzo de 1789, esta fecha fue tomada como inicio de las sesiones preparatorias; por su parte, las sesiones regulares comenzaban recién en diciembre, nueve meses después. Esta demora, justificable en el siglo XVIII, se fue tornando inadmisible con el correr del tiempo. Se le sumaba a ello que la elección de los senadores y diputados tiene lugar en los años pares, en el mes de noviembre, ${ }^{389}$ esto significaba, en la práctica, que un legislador elegido en noviembre recién tomaba posesión efectiva de la banca cuatro meses después, en marzo del año siguiente. Asimismo, las sesiones regulares recién comenzaban en diciembre de ese año, es decir, trece meses después de haber sido elegidos los nuevos legisladores. Durante ese período de cuatro meses (entre noviembre y marzo del año siguiente), tenían lugar las llamadas lame duck sessions, en las cuales no sesionaban los nuevos legisladores elegidos en la elección anterior, sino que lo hacían muchos de los que debían retirarse. Era frecuente, además, que estos aprovecharan la ocasión para entorpecer las sesiones por medio del filibuster.

Para terminar con esta anomalía, el senador republicano George W. Norris, de Nebraska, ${ }^{390}$ propuso en 1923 una enmienda constitucional para acortar el período que mediaba entre la elección de los legisladores y el inicio de un nuevo Congreso, estableciendo que las sesiones debían comenzar en enero en lugar de marzo. Pese a que la enmienda parecía ser bastante sencilla, en los hechos encontró una resistencia formidable en el House -donde los representantes que no eran reelegidos se veían perjudicados por ella- y su sanción se demoró casi una década.

En febrero de 1923, cuando ya estaba por finalizar el 67 Congreso (1921-

388 "Art. I, s. 4, cl. 2: The Congress shall assemble at least once in every Year, and such Meeting shall be on the first Monday in December, unless they shall by Law appoint a different Day".

389 En los Estados Unidos, el Election Day tiene lugar el martes siguiente al primer lunes del mes de noviembre de los años pares. Ese día, cada cuatro años, son elegidos el presidente y vicepresidente; y cada dos años, los senadores y representantes. Así fue establecido por una ley de 1845 para elegir al presidente y al vicepresidente (Presidential Election Day Act of 1845; 5 Statutes at Large 721), que se mantiene vigente en la actualidad en el 3 USC § 1: "The electors of President and Vice President shall be appointed, in each State, on the Tuesday next after the first Monday in November, in every fourth year succeeding every election of a President and Vice President”. Esta misma disposición fue adoptada también para los senadores (2 USC § 1) y para los representantes (2 USC § 7).

390 El mismo que, siendo miembro del House, había liderado la revuelta contra el Speaker Joseph Cannon en 1910. 
1923), fue aprobada por el Senado por un voto de 63-6. En el House fue aprobada por el Rules Committee, pero su presidente, el republicano Philip Campbell, de Kansas -un lame duck-, se encargó de impedir que llegara al recinto. Al año siguiente, durante el 68 Congreso (1923-1925), el Senado volvió a aprobarla por 63-7, pero el Rules Committee en el House la bloqueó; lo mismo ocurrió en 1926, luego de una votación favorable en el Senado de 72-3. Recién en 1928, durante el 70 Congreso (1927-1929), la Enmienda Norris pudo llegar al recinto del House luego de ser aprobada en el Senado - por cuarta vez- con un voto de 65-6. Si bien en esta ocasión en el House fue aprobada por 209-157 votos, estos no fueron suficientes para alcanzar la mayoría agravada de dos tercios que exige el artículo $\mathrm{V}$ de la Constitución para que una enmienda sea aprobada en el Congreso y pueda ser enviada a las legislaturas estatales para su ratificación. En el 71 Congreso (1929-1931), el Senado la aprobó nuevamente -una quinta vez- por 64-9, pero el House optó por una versión diferente por 290-93. Tampoco pudo ser sancionada en esa oportunidad porque ambas cámaras no lograron acordar el texto. ${ }^{391}$ La Enmienda finalmente pudo ser sancionada en el 72 Congreso (1931-1933), cuando los demócratas recobraron la mayoría en el House. A comienzos de 1932, el Senado la aprobó - por sexta vez- con una mayoría de 63-7 y el House hizo lo suyo con una mayoría 335-56.

Su ratificación en las legislaturas estatales no se demoró y la Enmienda Norris (Lame Duck Amendment) se convirtió en la Enmienda XX el 23 de febrero de $1933 .{ }^{392}$ Con ella fueron modificadas dos fechas importantes en el

391 Recordemos que en los Estados Unidos, en caso de desacuerdo entre el Senado y el House, no prevalece la cámara de origen, como ocurre en el sistema argentino, sino que se designa una comisión bicameral (conference committee) con el objeto de negociar el texto, que elabora el llamado conference report, el cual debe ser aprobado por ambas cámaras sin enmiendas. Esta solución no surge expresamente de la Constitución, pues el artículo I, sección 7, cláusula 2 solo establece que un proyecto, una vez aprobado por ambas cámaras, debe ser enviado al Poder Ejecutivo para que se convierta en ley ("Every Bill which shall have passed the House of Representatives and the Senate, shall, before it become a law, be presented to the President of the United States"). No obstante, es evidente que dicha cláusula no permite enviar al Poder Ejecutivo un proyecto sancionado solamente por una de las cámaras. No me detendré aquí en esta cuestión, pero puede ser consultada, entre otros lugares, en Congressional Research Service (2019). Puede verse también la obra de Bidegain (1950, pp. 626-632).

392 Su texto completo, en lo que aquí interesa, es el siguiente:

"Section 1. The terms of the President and Vice President shall end at noon on the 20th day of January, and the terms of Senators and Representatives at noon on the $3^{\text {rd }}$ day of January, of the years in which such terms would have ended if this article had not been ratified; and the terms of their successors shall then begin.

Section 2. The Congress shall assemble at least once in every year, and such meeting shall begin at noon on the $3 \mathrm{~d}$ day of January, unless they shall by law appoint a different day".

("Sección 1. Los períodos del Presidente y el Vicepresidente terminarán al medio día del veinte de 
calendario político de los Estados Unidos. La fecha de apertura de las sesiones del Congreso fue cambiada del primer lunes de diciembre al 3 de enero. ${ }^{393} \mathrm{Se}$ modificó también la fecha del Inauguration Day, es decir, el día en que toma posesión del cargo el presidente, que fue fijada el 20 de enero. ${ }^{394}$

\subsection{En marcha hacia la crisis}

En marzo de 1929, Herbert Hoover sucedió a Calvin Coolidge en la presidencia. El optimismo expresado por este último en su último mensaje al Congreso ${ }^{395}$ no permitía imaginar -al menos en un análisis superficial- lo que ocurriría menos de un año después. Sin embargo, la orgía especulativa a la que se habían entregado los norteamericanos en los años anteriores tuvo en las finanzas efectos devastadores que irrumpieron en la Bolsa de la Ciudad de New York el jueves 24 de octubre de aquel año y siguieron los días posteriores. ${ }^{396} \mathrm{~A}$ pesar de que muchos creyeron inicialmente que la ola podía ser detenida, ${ }^{397}$ lo cierto es que los nefastos efectos del Jueves Negro se prolongaron durante la década posterior, signada por la Gran Depresión. ${ }^{398}$ A partir de allí, toda la ad-

enero y los períodos de los senadores y representantes al medio día del tres de enero, de los años en que dichos períodos habrían terminado si este artículo no hubiera sido ratificado, y en ese momento principiarán los períodos de sus sucesores. Sección 2. El Congreso se reunirá, cuando menos, una vez cada año y dicho período de sesiones se iniciará al mediodía del tres de enero, a no ser que por medio de una ley fije una fecha diferente").

393 La primera sesión reunida en esa fecha tuvo lugar en 1934, durante el 73॰ Congreso (1935-1937).

394 Hasta ese momento, casi todos los presidentes habían asumido el 4 de marzo. El primer presidente en tomar posesión del cargo el 20 de enero fue Franklin D. Roosevelt, en 1937, al inaugurar su segundo mandato.

395 "Ninguno de los Congresos de los Estados Unidos hasta ahora reunidos para examinar el estado de la Unión -decía el mensaje- se ha encontrado ante una perspectiva tan favorable como la que aparece en los actuales momentos. En el terreno doméstico hay tranquilidad y satisfacción [...] y el más alto récord de años de prosperidad. En el campo exterior hay paz, y esa sinceridad nacida de la comprensión mutua”. El Presidente luego les dijo a los legisladores que ellos y el país podían considerar el presente con satisfacción y anticipar el futuro con optimismo. Ver Galbraith (1992, p. 30).

396 Según explica Galbraith (1992, p. 133), el peor día de la crisis fue el martes 29. Lo califica como la jornada más devastadora de la historia de la Bolsa de New York.

397 El propio Hoover alentó esta creencia diciendo que la crisis sería superada en 60 días (New York Times, 8 de marzo de 1930, como se citó en De Gregorio, 2005, p. 473).

398 Dice Galbraith (1992): "Luego del Gran Crac vino la Gran Depresión, que duró -con cambiante severidad- diez años. En 1933 el Producto Bruto Nacional (producción total de la economía) fue aproximadamente una tercera parte inferior al de 1929. Recién en 1937 el volumen físico de la producción alcanzó los niveles de 1929; pero inmediatamente volvieron a retroceder. Hasta 1941 el valor de la producción en dólares fue menor que el de 1929. Entre 1930 y 1940 solo en una ocasión -1937- bajó durante el año de ocho millones el número de desocupados. En 1933 había en Estados 
ministración de Hoover -quien no atinó a ponerle remedio a la crisis- quedó ensombrecida por los fantasmas del desempleo y la quiebra masiva de bancos y empresas. ${ }^{399}$ El propio presidente vio así demolido su prestigio -ganado como buen administrador durante la época de la guerra- y se convirtió en el símbolo del desastre, ${ }^{400}$ encerrado en su crédito económico-liberal que le impedía adoptar las medidas que recién fueron encaradas por su sucesor.

\section{Conclusión}

Tratándose de una reseña histórica parcial, que espero algún día poder completar hasta la actualidad, no es posible todavía arribar a conclusiones muy definitivas, si es que estas pueden hacerse sobre una institución que está en desarrollo constante.

En ausencia de ellas, diré tan solo que, sin perjuicio de la enorme influencia política ejercida por algunos presidentes notables como Washington, Lincoln y Wilson, el Congreso, durante el siglo y medio que abarca el período aquí considerado, logró emerger y afianzarse como una legislatura estable que nunca interrumpió sus actividades -ni siquiera en plena Guerra Civil-, convirtiéndose en el foro de discusión de los problemas nacionales más trascendentales, en cuyo debate, incluso, desafió a mandatarios poderosos como los mencionados.

No ha estado exento de la pasión ni de los defectos propios de toda institución de su tipo, pero ha contribuido con eficacia a equilibrar el balance poderes.

\section{Bibliografía}

Abraham, H. J. (1985). Justices and Presidents. A Political History of Appointments to the Supreme Court (2 ed.). Oxford University Press.

Angle, P. M. (Ed.). (1991). The Complete Lincoln-Douglas Debates of 1858. The University of Chicago Press.

Unidos casi trece millones de trabajadores sin empleo, es decir, uno por cada cuatro del total de la fuerza de trabajo del país. En 1938 una persona de cada cinco seguía todavía sin empleo” (p. 186).

399 En la primavera de 1930 había cuatro millones de desempleados, cifra que se triplicó en 1933, el peor año de la Depresión, en el que se registró una tasa de desempleo del $25 \%$.

400 Los miles de desempleados que se vieron forzados a abandonar sus hogares pasaron a vivir precariamente en viviendas de cartón y hojalata a las que se llamó hoovervilles. 
Anthony, S. B. (1887-1922). The History of Women Suffrage (Vols. 1-6). National American Suffrage Association.

Baker, George W. (Jr.). (1966). The Wilson Administration and Panama, 1913-1921. Journal of Inter-American Studies, 8(2), 279-293.

Beard, C. A. (1956). An Economic Interpretation of the Constitution of the United States. The Macmillan Co.

Belz, H. (Ed.). (2000). The Webster-Hayne Debate on the Nature of the Union. Selected Documents. Liberty Fund.

Bianchi, A. B. (2008). Historia Constitucional de los Estados Unidos (Tomo I). Cathedra Jurídica.

Bidegain, C. M. (1950). El Congreso de Estados Unidos de América. Derecho y Prácticas Legislativas. Depalma.

Bowen, C. D. (1966). Miracle at Philadelphia. The story of the Constitutional Convention May to September 1787. Little Brown \& Co.

Bueno de Mesquita, B. y Smith, A. (2016). The Spoils of War. Public Affairs Books.

Carey, G. W. (1989). The Federalist. Design for a Constitutional Republic. University of Illinois Press.

Carey, G. y McLean, J. (2001 [1818]). Gideon Edition. Liberty Fund.

Cheathem, M. R. (2018). Andrew Jackson and the Rise of the Democratic Party. University of Tennessee.

Chernow, R. (2005). Alexander Hamilton. Penguin Books.

Congressional Research Service. (21 de mayo de 2019). Conference Committee and Related Procedures: An Introduction. https://fas.org/sgp/crs/misc/96-708.pdf.

Davison, K. E. (1972). The Presidency of Rutherford B. Hayes. Greenwood Press.

De Gregorio, W. A. (2005). The Complete Book of U.S. Presidents (5a ed.). Wings Books.

Dickson, P. y Clancy, P. (Eds.). (1993). The Congress Dictionary. John Wiley and Sons, Inc.

Farrand, M. (1911a). The Records of the Federal Convention of 1787 (Vol. 1). Yale University Press. https://oll.libertyfund.org/title/farrand-the-records-of-the-federal-convention-of-17873vols.

Farrand, M. (1911b). The Records of the Federal Convention of 1787 (Vol. 2). Yale University Press. https://oll.libertyfund.org/title/farrand-the-records-of-the-federal-convention-of-17873vols.

Farrand, M. (1911c). The Records of the Federal Convention of 1787 (Vol. 3, Appendix F). Yale University Press. https://oll.libertyfund.org/title/farrand-the-records-of-the-federal-convention-of-1787-3vols.

Farrand, M. (1913). The Framing of the Constitution of the United States. Yale University Press.

Galbraith, J. K. (1992). The Great Crash 1929. Penguin Books.

Galloway, G. B. (1976). History of the House of Representatives (2a ed.). Thomas Y. Crowell.

Gaustad, E. S. (1968). The Great Awakening in New England. Quadrangle.

Gould, L. L. (1991). The Presidency of Theodore Roosevelt. University Press of Kansas.

Gould, L. L. (2003). Grand Old Party. A History of the Republicans. Random House.

Grant, J. (2011). Mr. Speaker!: The Life and Times of Thomas B. Reed, The Man Who Broke the Filibuster. Simon \& Schuster.

Guide to Congress. (2015). (7 ed.). Congressional Quarterly.

Hasbrouck, P. D. (1972). Party Government in The House of Representatives. Macmillan. 
Haynes, G. H. (1938). The Senate of the United States. Its History and Practice (Vol. 1). Houghton Mifflin Co.

Hazelgrove, W. (2016). Madam President: The Secret Presidency of Edith Wilson. Regnery History. Hecht, M. B. (1972). John Quincy Adams. A Personal History of an Independent Man. Macmillan. Hendricks, N. (2013). Senator Hattie Caraway: An Arkansas Legacy. The History Press.

Holt, M. F. (1999). The Rise and Fall of the American Whig Party: Jacksonian Politics and the Onset of the Civil War. Oxford University Press.

James Madison Writings. (1999). The Library of America, Literary Classics of the United States. Jeffers, P. A. (2000). An Honest President: The Life and Presidencies of Grover Cleveland. Morrow.

Johnson, P. (1997). A History of the American People. Harper Collins.

Jones, C. O. (1970). The Minority Party in Congress. Little Brown \& Co.

Kendrick, B. B. (1969 [1914]). The Journal of the Joint Committee of Fifteen on Reconstruction, 39th Congress, 1865-1867. Negro Universities Press.

Kravitz, W. (1974). Evolution of the Senate's Committee System. The Annals of the American Academy of Political and Social Science, 411(1), 27-38.

Link, A. S. (1954). Woodrow Wilson and the Progressive Era. Harper \& Brothers.

Link, A. S. (1966-1994). The Papers of Woodrow Wilson. Princeton University Press.

Link, A. S. (1982). Woodrow Wilson and a Revolutionary World. University of North Carolina Press.

Lopach, J. J. y Luckowski, J. A. (2018). Jeannette Rankin: A Political Woman. University Press of Colorado.

MacNeil, N. (2011). Forge of Democracy: The House of Representatives.

Mayo, B. (1937). Henry Clay. Spokesman of the New West. Houghton Mifflin.

McCartney, L. (2009). The Teapot Dome Scandal. Random House.

Mee, C. L. (Jr.). (2014). The Ohio Gang: The World of Warren G. Harding. M. Evans \& Company.

Meed, D. (2002). The Mexican War 1846-1848. Osprey Publishing Limited.

Miller, N. (1992). Theodore Roosevelt. A Life. William Morrow.

Morison, S. E., Commager, H. S. y Leuchtenburg, W. E. (1980). The Growth of the American Republic (7 a ed., Vol. I). Oxford University Press.

Patrick, J. J., Piuos, R. M. y Ritchie, D. A. (Eds.). (2001). The Oxford Guide to the United States Government. Oxford University Press.

Perret, G. (1997). Ulysses S. Grant: Soldier and President. Random House.

Purcell, L. E. (2001). Vice Presidents: A Biographical Dictionary. Checkmark Books.

Reeves, T. C. (1991). Gentleman Boss: The Life of Chester Alan Arthur. American Political Bibliography Press.

Riddick, F. M. (1949). The United States Congress. Organization and Procedures. National Capitol Publishers.

Rimini, R. V. (2006). The House. The History of the House of Representatives. Harper Collins.

Rothman, D. J. (1966). Politics and Power. The United States Senate (1861-1901). Harvard University Press.

Schiller, W. J., Stewart, C. y Xiong, B. (2013). U.S. Senate Elections before the 17th Amendment: Political Party Cohesion and Conflict 1871-1913. The Journal of Politics, 75(3), 835-847.

Schumpeter, J. A. (1971). Historia del análisis económico. Ariel.

Singer, A. (1976). Campaign Speeches of American Presidential candidates, 1928-1972. Ungar. 
Sobel, R. (2015). Coolidge: An American Enigma. Regnery History.

Socolofsky, H. y Spetter, A. B. (1987). The Presidency of Benjamin Harrison. University Press of Kansas.

Story, J. (1858). Commentaries on the Constitution of the United States (3a ed., libro 1). Little Brown $\&$ Co.

Thelen, D. P. (1976a). La Follette and the Insurgent Spirit. The University of Wisconsin Press.

Thelen, D. P. (1976b). Robert M. La Follette and the Insurgent Spirit. Little Brow \& Co.

Wilson, W. (2017 [1885]). Congressional Government. A Study in American Politics, Okitos Press.

Wineapple, B. (2020). The Impeachers: The Trial of Andrew Johnson and the Dream of a Just Nation. Random House.

Women in Congress: Statistics and Brief Overview (2021). Congressional Research Service. https:// fas.org/sgp/crs/misc/R43244.pdf.

\section{Anexo I}

Virginia, la más antigua de las colonias, fue fundada por la Virginia Stock Company of London, merced a una carta otorgada por Jacobo (James) I en 1606 y dio lugar a la fundación de Jamestown en 1607, el primer asentamiento inglés permanente en América. Maryland nació a raíz de la carta otorgada a George Calvert en 1632 por el rey Carlos I. Nacida como un refugio para ingleses católicos, su primer asentamiento tuvo lugar en St. Mary’s en 1634, luego llegaron oleadas de protestantes, lo que provocó conflictos entre ambos grupos.

Massachusetts tuvo su origen en el desembarco de los padres peregrinos que arribaron a las costas de Cape Code en 1620 y fundaron Plymouth ese mismo año. En 1629 fue fundada Charlestown y en 1630 desembarcaron allí John Winthrop y otros emprendedores de la Massachusetts Bay Company y fundaron la ciudad de Boston, entre otras.

Connecticut nació por medio de una carta real otorgada por Carlos II en 1662, que unificó los territorios colonizados por Thomas Hooker, que había fundado Hartford en 1636 y por otros puritanos que se habían establecido en Saybrook y New Haven en la misma época. Rhode Island nació como resultado de la disidencia de Roger Williams, un fervoroso adherente de la libertad religiosa, con el Gobierno de Winthrop y los puritanos. Rogers fundó Providence en 1636 y con la reunión de varios asentamientos poblados por librepensadores se federaron en Rhode Island hacia 1644. En 1663 obtuvieron una carta real propia.

New Hampshire fue fundada por varios grupos de puritanos y anglicanos que, entre 1623 y 1640 , se establecieron en tierras otorgadas por Carlos I a John Mason. Estos asentamientos fueron convertidos en colonia real en 1679.

En New York se instaló originalmente la Dutch West Indies Company, que fundó Albany en 1624 y Manhattan en 1626. En 1664, los ingleses se apoderaron de la colonia, expulsaron a los holandeses y la denominaron New York, debido a una concesión de esas tierras que Carlos II le había hecho a su hermano, el duque de York. En 1685, Jacobo II, el otrora duque de York, que había ascendido al trono como consecuencia de la muerte de su hermano, la convirtió en colonia real.

New Jersey se originó en 1665 por medio de una carta otorgada por el entonces duque de 
York (luego Jacobo II), que le otorgó tierras a lord John Berkeley y a George Calvert, quienes denominaron New Jersey a dicha área, dividiéndola en East Jersey y West Jersey. Ambos propietarios vendieron estas parcelas separadamente y volvieron a unirse en una sola colonia en 1702, que hasta 1738 estuvo bajo la autoridad del gobernador de New York.

Pennsylvania fue fundada por William Penn -un cuáquero- mediante una autorización otorgada por el duque de York en 1681. Penn atrajo a muchos de sus pobladores iniciales, tanto ingleses como europeos continentales, prometiéndoles la libertad religiosa y el otorgamiento de tierras, quienes en 1683 fundaron Germantown. Hasta la Revolución, en 1776, Pennsylvania fue una colonia particular.

Delaware fue colonizada originalmente por holandeses y suecos. Los primeros fundaron la ciudad de Lewes en 1631. En 1664, los ingleses tomaron posesión de estos territorios, que fueron incluidos en una concesión otorgada al duque de York, que se los vendió en 1682 a William Penn, pasándose a llamar los Lower Counties. Al igual que Pennsylvania, Delaware continuó siendo una colonia particular hasta 1776. El territorio que hoy ocupan North y South Carolina fue originalmente una extensión de tierras ubicada entre Virginia y Florida, otorgada en 1683 por Carlos II a sir John Colleton y al conde de Shaftesbury. Charleston, en la actual South Carolina, fue fundada en 1670.

South Carolina fue esencialmente una colonia de plantaciones y en North Carolina predominaron las granjas. Ambas se convirtieron en colonias reales en 1729. Georgia, finalmente, fue inicialmente un refugio para los deudores, fundado por James Edward Oglethorpe, un militar inglés y miembro del Parlamento que, junto con otro grupo de filántropos reformistas, intentaba aliviar con ello la dureza de la justicia británica para con los deudores morosos. Fundaron Savannah en 1733 y Georgia obtuvo el estatus de colonia real en 1752 (Guide to Congress, 2015, p. 4).

\section{Anexo II}

1. "[...] the articles of Confederation ought to be so corrected \& enlarged as to accomplish the objects proposed by their institution; namely: 'common defence, security of liberty and general welfare'.

2. [...] the rights of suffrage in the National Legislature ought to be proportioned to the Quotas of contribution, or to the number of free inhabitants, as the one or the other rule may seem best in different cases.

3. [...] the National Legislature ought to consist of two branches.

4. [...] the members of the first branch of the National Legislature ought to be elected by the people of the several States everyfor the term of; to be of the age of years at least, to receive liberal stipends by which they may be compensated for the devotion of their time to public service; to be ineligible to any office established by a particular State, or under the authority of the United States, except those beculiarly belonging to the functions of the first branch, during the term of service, and for the space ofafter its expiration; to be incapable of re-election for the space ofafter the expiration of their term of service, and to be subject to recall. 
5. [...] the members of the second branch of the National Legislature ought to be elected by those of the first, out of a proper number of persons nominated by the individual Legislatures, to be of the age ofyears at least; to hold their offices for a term sufficient to ensure their independency, to receive liberal stipends, by which they may be compensated for the devotion of their time to public service; [21] and to be ineligible to any office established by a particular State, or under the authority of the United States, except those peculiarly belonging to the functions of the second branch, during the term of service, and for the space ofafter the expiration thereof.

6. [...] each branch ought to possess the right of originating Acts; that the National Legislature ought to be impowered to enjoy the Legislative Rights vested in Congress by the Confederation $\&$ moreover to legislate in all cases to which the separate States are incompetent, or in which the harmony of the United States may be interrupted by the exercise of individual Legislation; to negative all laws passed by the several States, contravening in the opinion of the National Legislature the articles of Union; and to call forth the force of the Union against any member of the Union failing to fulfill its duty under the articles thereof.

7. [...] a National Executive be instituted; to be chosen by the National Legislature for the term of years, to receive punctually at stated times, a fixed compensation for the services rendered, in which no increase or diminution shall be made so as to affect the Magistracy, existing at the time of increase or diminution, and to be ineligible a second time; and that besides a general authority to execute the National laws, it ought to enjoy the Executive rights vested in Congress by the Confederation.

8. [...] the Executive and a convenient number of the National Judiciary, ought to compose a council of revision with authority to examine every act of the National Legislature before it shall operate, \& every act of a particular Legislature before a Negative thereon shall be final; and that the dissent of the said Council shall amount to a rejection, unless the Act of the National Legislature be again passed, or that of a particular Legislature be again negatived by of the members of each branch.

9. [...] a National Judiciary be established to consist of one or more supreme tribunals, and of inferior tribunals to be chosen by the National Legislature, to hold their offices during good behaviour; and to receive punctually at stated times fixed compensation for their services, in which no increase or diminution shall be made so as to affect the persons actually in office at the time of such increase or diminution. that the jurisdiction of the inferior tribunals shall be to hear \& determine in the first instance, and of the supreme tribunal to hear and determine in the dernier resort, all piracies $\&$ felonies on the high seas, captures from an enemy; cases in which foreigners or citizens of other States applying to such jurisdictions may be interested, or which respect the collection of the National revenue; impeachments of any National officers, and questions which may involve the national peace and harmony.

10. [...] provision ought to be made for the admission of States lawfully arising within the limits of the United States, whether from a voluntary junction of Government \& Territory or otherwise, with the consent of a number of voices in the National legislature less than the whole. 
11. [...] a Republican Government \& the territory of each State, except in the instance of a voluntary junction of Government \& territory, ought to be guaranteed by the United States to each State.

12. [...] provision ought to be made for the continuance of Congress and their authorities and privileges, until a given day after the reform of the articles of Union shall be adopted, and for the completion of all their engagements.

13. [...] provision ought to be made for the amendment of the Articles of Union whensoever it shall seem necessary, and that the assent of the National Legislature ought not to be required thereto.

14. [...] the Legislative Executive \& Judiciary powers within the several States ought to be bound by oath to support the articles of Union

15. [...] the amendments which shall be offered to the Confederation, by the Convention ought at a proper time, or times, after the approbation of Congress to be submitted to an assembly or assemblies of Representatives, recommended by the several Legislatures to be expressly chosen by the people, to consider \& decide thereon”. Vid. Farrand (1911a, pp. 20-22). También puede verse el texto del Plan en James Madison Writings (1999, pp. 89-91).

\section{Anexo III}

1. "[...] the articles of Confederation ought to be so revised, corrected and enlarged, as to render the federal Constitution adequate to the exigencies of Government, and the preservation of the Union.

2. [...] in addition to the powers vested in the United States in Congress, by the present existing articles of Confederation, they be authorized to pass acts for raising a revenue, by levying a duty or duties on all goods or merchandizes of foreign growth or manufacture, imported into any part of the United States, by Stamps on paper, vellum or parchment, by a postage on all letters or packages passing through the general post-Office, to be applied to such federal purposes as they shall deem proper and expedient; to make rules and regulations for the collection thereof; the same from time to time, to alter and amend in such manner as they shall think proper: to pass Acts for the regulation of trade and commerce as well with foreign nations as with each other: provided that all punishments, fines, forfeitures and penalties to be incurred for contravening such acts rules regulations shall be adjudged by the Common law Judiciary of the State in which any offence contrary to the true intent and meaning of such Acts rules and regulations shall have been committed or perpetrated, with liberty of commencing in the first instance all suits and prosecutions for that purpose in the superior Common law Judiciary in such State, subject nevertheless, for the correction of all errors, both in law and fact in rendering judgment, to an appeal to the Judiciary of the U. States

3. [...] whenever requisitions shall be necessary, instead of the rule for making requisitions mentioned in the articles of Confederation, the United States in Congress be authorized to make such requisitions in proportion to the whole number of white and other free citizens and 
inhabitants of every age sex condition including those bound to servitude for a term of years and three fifths of all other persons not comprehended in the foregoing description, except Indians not paying taxes; that if such requisitions be not complied with, in the time specified therein, to direct the collection thereof in the non complying States for that purpose to devise pass acts directing authorizing the same; provided that none of the powers hereby vested in the United States in Congress shall be exercised without the consent of at least States, in that proportion if the number of Confederated States should hereafter be increased or diminished.

4. [...] the United States in Congress be authorized to elect a federal Executive to consist of persons, to continue in office for the term of years, to receive punctually at stated times a fixed compensation for their services, in which no increase or diminution shall be made so as to affect the persons composing the Executive at the time of such increase or diminution, to be paid out of the federal treasury; to be incapable of holding any other office or appointment during their time of service for years thereafter; to be ineligible a second time, removable by Congress on application by a majority of the Executives of the several States; that the Executives besides their general authority to execute the federal acts ought to appoint all federal officers not otherwise provided for, and to direct all military operations; provided that none of the persons composing the federal Executive shall on any occasion take commission of any troops, so as personally to conduct any enterprise as General, or in other capacity.

5. [...] a federal Judiciary be established to consist of a supreme Tribunal the Judges of which to be appointed by the Executive, and to hold their offices during good behaviour, to receive punctually at stated times a fixed compensation for their services in which no increase or diminution shall be made, so as to affect the persons actually in office at the time of such increase or diminution; that the Judiciary so established shall have authority to hear and determine in the first instance on all impeachments of federal officers, by way of appeal in the dernier resort in all cases touching the rights of Ambassadors, in all cases of captures from an enemy, in all cases of piracies and felonies on the high seas, in all cases in which foreigners may be interested, in the construction of any treaty or treaties, or which may arise on any of the Acts for regulation of trade, or the collection of the federal Revenue: that none of the Judiciary shall during the time they remain in Office be capable of receiving or holding any other office or appointment during their time of service, or for thereafter.

6. [...] all Acts of the United States in Congress made by virtue in pursuance of the powers hereby and by the articles of confederation vested in them, all Treaties made ratified under the authority of the United States shall be the supreme law of the respective States so far forth as those Acts or Treaties shall relate to the said States or their Citizens, that the Judiciary of the several States shall be bound thereby in their decisions, anything in the respective laws of the Individual States to the contrary notwithsting; that if any State, or any body of men in any State shall oppose or prevent the carrying into execution such acts or treaties, the federal Executive shall be authorized to call forth ye power of the Confederated States, or so much thereof as may be necessary to enforce compel an obedience to such Acts, or an Observance of such Treaties.

7. [...] provision be made for the admission of new States into the Union. 
8. [...] the rule for naturalization ought to be the same in every State

9. [...] a Citizen of one State committing an offence in another State of the Union, shall be deemed guilty of the same offence as if it had been committed by a Citizen of the State in which the Offence was committed" (Farrand, 1911a, 242-245).

\section{Anexo IV}

"Resolved that in the original formation of the Legislature of the U.S. the first branch thereof shall consist of sixty-five members, of which number N. Hampshire shall send 3. Massts. 8. Rh. I. 1. Connt. 5. N. Y. 6. N. J. 4. Pena. 8. Del. 1. Maryd. 6. Virga. 10. N. C. 5. S. C. 5. Geo. 3. - But as the present situation of the States may probably alter in the number of their inhabitants, the Legislature of the U.S. shall be authorized from time to time to apportion the number of Reps.; and in case any of the States shall hereafter be divided, or enlarged by, addition of territory, or any two or more States united, or any new States created within the limits of the U. S. the Legislature of the U.S. shall possess authority to regulate the number of Reps, in any of the foregoing cases, upon the principle of their number of inhabitants, according to the provisions hereafter mentioned, namely - provided always that representation ought to be proportioned according to direct taxation; and in order to ascertain the alteration in the direct taxation, which may be required from time to time by the changes in the relative circumstances of the States. Resolved that a Census be taken within six years from the 1st. meeting of the Legislature of the U. S. and once within the term of every 10 years afterwards of all the inhabitants of the U. S. in the manner and according to the ratio recommended by Congress in their Resolution of April 18. 1783. and that the Legislature of the U. S. shall proportion the direct taxation accordingly. Resolved, that all bills for raising or appropriating money, and for fixing the salaries of officers of the Govt. of the U.S. shall originate in the first branch of the Legislature of the U. S. and shall not be altered or amended in $2 \mathrm{~d}$. branch: and that no money shall be drawn from the public Treasury, but in pursuance of appropriations to be originated in the 1 st branch. Resolved that in the $2 \mathrm{~d}$. branch of the Legislature of the U. S. each State shall have an equal vote" (Farrand, 1911a, pp. 13-14).

\section{Anexo V}

Conforme a lo establecido en el artículo VII, eran necesarias 9 ratificaciones para que la Constitución entrara en vigencia. El 6 de diciembre de 1787, dos meses después de firmada la Constitución, la convención de Delaware unánimemente ratificó la Constitución, convirtiéndose en el primero de los estados en hacerlo. Menos de una semana después, el 12 de diciembre, lo hizo Pennsylvania por mayoría de 46 a 23 votos y con gran oposición de los antifederalistas. El 22 de diciembre se sumó New Jersey y poco después, el 2 de enero de 1788, ratificó Georgia. El quinto estado fue Connecticut, que aprobó la Constitución con una mayoría de 128 votos contra 42. En sexto lugar vino Massachusetts, cuya convención se reunió el 9 de enero de 1788, y luego de un acalorado debate y negociaciones de variado tipo, en el que surgió además la necesidad 
de sancionar un Bill of Rights, se obtuvo la ratificación el 6 de febrero por una estrecha mayoría de 187 a 168. John Hancock había sido designado presidente de la Convención, pero se negó a ocupar su puesto hasta que le prometieron apoyo a su candidatura como vicepresidente en la elección nacional, que tendría lugar luego de ratificada la Constitución. Samuel Adams se opuso también hasta que se produjeron algunos acuerdos comerciales para la construcción de buques en los que se hallaba interesado. Siguieron Maryland, el 28 de abril, con una votación 63 a 11, en la que también se propuso un Bill of Rights, y en octavo lugar se produjo la ratificación de South Carolina, el 23 de mayo, con una mayoría de 149 a 46. El noveno estado fue New Hampshire, al que le corresponde el honor de haber dado su voto para la entrada en vigencia de la Constitución. Ello se produjo el 21 de junio por un voto de 57 a 46.

No obstante la entrada en vigencia formal, todavía estaban fuera cuatro estados que reunían el 40 por ciento de toda la población, entre ellos, Virginia -el más poderoso-, sin cuya aprobación no podía hablarse de éxito. Ello tuvo lugar el 23 de junio en una votación dividida 89 a 79, en la cual quedó planteada también la necesidad de incorporar un Bill of Rights. Quedaban todavía New York, North Carolina y Rhode Island, cuyos votos a esa altura ya se daban por descontados. En New York, sin embargo, el debate fue intenso entre el gobernador Clinton, alineado con los antifederalistas, y Alexander Hamilton y John Jay, a favor de la ratificación. El 26 de julio se produjo la ratificación por un escaso margen de 30 a 27 y con gestos de agitación por los antifederalistas, quienes en Albany, capital del estado, llegaron a quemar un ejemplar de la Constitución. Luego ratificó North Carolina el 21 noviembre de 1789. El último de los trece estados originales en ratificar la Constitución fue Rhode Island, que lo hizo en mayo de 1790 mediante una convención convocada ese mismo año.

Ya con anterioridad, el 13 de septiembre de 1788, el Congreso de la Confederación había declarado que la Constitución estaba debidamente ratificada y habían dado comienzo los preparativos para la elección del presidente. Se fijó el primer miércoles de enero de 1789 para la designación de los electores y el primer miércoles de febrero para la elección del presidente. Se estableció, asimismo, que el período presidencial comenzaría el miércoles 4 de marzo. No obstante, recién el 30 de abril de ese año dio comienzo el período presidencial de George Washington. Se decidió también que New York sería la ciudad capital del nuevo Gobierno. Ver, entre muchos otros, Morison et al., (1980, pp. 257-261) y Bowen (1966, pp. 267-310).

\section{Anexo VI}

Brevemente mencionados, los hechos que dieron lugar a la Guerra Civil fueron los siguientes.

Hacia fines de la década de 1850, los estados del sur podían sentirse satisfechos con los resultados obtenidos en el reparto de la esclavitud. Con la Ley Kansas-Nebraska habían abierto una puerta para expandirla hacia el norte y la Corte Suprema -en el caso Strader v. Graham, 51 U.S. 395 (1851) y más especialmente en Dred Scott v. Sandford, 60 U.S. 393 (1859)- había hecho sentir su espíritu sureño.

Sin embargo, en 1860 ocurrió un hecho que desencadenó la tormenta y rompió con este 
frágil esquema. Finalizaba la opaca presidencia de James Buchanan (1857-1861), que no se presentó para una nueva candidatura, y la elección ofrecía un frente político complejo para los esclavistas, pues el Partido Demócrata se dividió en tres facciones, cada una con su candidato. Stephen Douglas, de Illinois, fue nominado por los norteños; John C. Breckinridge, de Kentucky, resultó electo por los sureños; y un grupo remanente que había formado el Constitutional Union Party eligió a John Bell, de Tennessee.

Todos ellos competían con Lincoln, propuesto por el recientemente formado Partido Republicano, quien había saltado a la primera plana política luego de sus debates con Douglas. Si bien en su campaña Lincoln había sido bastante moderado, pues no proponía eliminarla allí donde existía sino tan solo controlar su expansión, los estados del sur igualmente lo veían como una amenaza. Tanto era el temor de que la esclavitud sufriera alguna mengua que South Carolina anunció su propósito de segregarse si Lincoln ganaba. Y así fue. Lincoln ganó la elección con una mayoría del 40 por ciento sobre el segundo, que resultó ser Douglas con el 29 por ciento.

South Carolina entonces cumplió su promesa y el 20 de diciembre de 1860 sancionó su Ordenanza de Secesión. Inmediatamente, este movimiento se esparció como un reguero de pólvora. La siguieron Mississippi (9 de enero de 1861), Florida (10 de enero), Alabama (11 de enero), Georgia (19 de enero), Louisiana (26 de enero), Texas (26 de febrero), Arkansas (6 de mayo), North Carolina (20 de mayo), Virginia (23 de mayo), Tennessee (8 de junio), Missouri (31 de octubre) y Kentucky (20 de noviembre).

Así, un año después de la elección de Lincoln, trece estados habían decidido segregarse formalmente de la Unión y ya formaban un nuevo estado soberano bajo su propia constitución. Sin perder tiempo, los primeros estados segregados comenzaron por elegir un nuevo presidente. La elección recayó en Jefferson Davis, primer y único presidente que tuvo la Confederación. Menos de un mes después, el 11 de marzo de 1861, representantes de los estados de South Carolina, Georgia, Florida, Alabama, Mississippi, Louisiana y Texas sancionaron la Constitución de los Estados Confederados. Su texto no era esencialmente distinto al de la Constitución de 1787, salvo las disposiciones referidas a la esclavitud, que le prohibían expresamente al Congreso dictar leyes que menoscabaran el derecho de propiedad sobre esclavos negros.

Esta situación, ciertamente, no podía mantenerse por mucho tiempo sin caer en una contienda armada. Las hostilidades comenzaron el 11 de abril de 1861, cuando las tropas confederadas exigieron la rendición del Fort Sumpter -una instalación militar del Gobierno federal ubicada en la bahía de Charleston, en South Carolina, la cual, mal defendida, fue tomada por los sureños-, y concluyeron cuatro años después, en abril de 1865 -con un saldo de más de 600000 muertos-, cuando el general Lee se rindió ante el general Grant en Appomattox.

\section{Anexo VII}

Luego del fortalecimiento de los poderes presidenciales durante la Guerra Civil, el mando político del Poder Ejecutivo decayó a niveles que solo se recuperarían hacia el fin del siglo XIX con presidentes fuertes como Theodore Roosevelt y Woodrow Wilson. Así, durante las últimas 
tres décadas del siglo XIX, los ocupantes de la Casa Blanca -dominada preponderantemente por el Partido Republicano- distaron de ser personalidades brillantes.

Ulysses S. Grant (1869-1877), un coloso en el campo de batalla de la Guerra Civil, fue en cambio un presidente mediocre que, obligado a enfrentar los problemas de la Reconstrucción y el ajuste económico, no supo elegir a los asesores apropiados y evitar la corrupción. Apoyándose en la maquinaria republicana, no pudo acabar con el sistema que otorgaba los cargos federales como recompensa a la lealtad política. Además, su inexperiencia en asuntos económicos y su ambición lo convirtieron en fácil presa de aventureros sin escrúpulos. Asimismo, animado por la incorporación final de todos los estados a la Unión, intentó llevar a cabo la reforma del Congreso, pero a la larga no supo mantenerla. Defendió también los derechos de los esclavos libres, pero no pudo evitar la reaparición del racismo en casi todos los estados sureños. En 1872, los disidentes reformistas de su partido organizaron el Liberal Republican Party y eligieron a Horace Greeley como candidato presidencial. Aunque Grant fue reelegido, su segunda administración se vio afectada por diversos casos de soborno y corrupción, en los que se vieron involucrados el vicepresidente, Schuyler Colfax, y el secretario de Guerra, William W. Belknap, entre otros. Todo esto contribuyó al fracaso de su Gobierno, a lo que se le unió la depresión económica de 1873, que dio como resultado una enorme cantidad de desempleados y la pérdida de la mayoría en la Cámara de Representantes, que pasó a estar presidida por los demócratas. Solo tuvo algunos éxitos en política exterior. Sufrió un revés inicial en el Senado, que no aprobó su plan de comprar la isla de Santo Domingo. Sin embargo, Hamilton Fish -como secretario de Estado- pudo zanjar las dificultades existentes con Gran Bretaña tras la firma del Tratado de Washington (1871) y mantuvo la neutralidad de Estados Unidos durante la guerra de los Diez Años que enfrentó a España y Cuba por la independencia de esta. Sobre la vida de Grant puede verse Perret (1997).

Su sucesor, Rutherford B. Hayes (1877-1881), llegó a la presidencia debilitado por la tumultuosa elección de 1866 a la que ya me referí y se vio envuelto también en los problemas de la Reconstrucción, en la necesidad de restaurar el poder de la presidencia y combatir la corrupción política esparcida bajo su antecesor. Bien intencionado en sus objetivos y honesto en su proceder, Hayes se propuso restaurar el poder que la presidencia había perdido con sus dos antecesores (Andrew Johnson y Ulysses Grant), apaciguar a los estados del sur y conformar a sus opositores demócratas, lo que generó un conflicto con su propio partido. Distribuyó cargos entre demócratas sudistas moderados y retiró las últimas tropas federales de los estados del sur. Como medio para combatir la corrupción administrativa, les prohibió a los funcionarios públicos intervenir en campañas políticas y manejar donativos. Esta decisión lo puso en conflicto con el senador Roscoe Conkling, líder republicano que manejaba la aduana de New York como un feudo personal. Al frente de ella se hallaba Chester Arthur, futuro presidente, que fue removido. En política monetaria, Hayes apoyó los esfuerzos de su secretario del Tesoro, John Sherman, para reconvertir los billetes de dólares emitidos durante la Guerra Civil estadounidense en oro. Debió enfrentar también graves disturbios laborales producidos en 1877, los cuales fueron reprimidos con tropas federales y produjeron muertos y heridos. Prefirió no 
presentarse a la reelección y en 1881 se retiró a Fremont (Ohio), donde murió el 17 de enero de 1893. Véase Davison (1972).

A Hayes lo sucedió James A. Garfield (1881), protagonista de una breve presidencia interrumpida por su asesinato, ocurrido a los pocos meses de asumir. Su muerte colocó en el sillón presidencial al vicepresidente, Chester A. Arthur (1881-1885), un personaje directamente asociado a la corrupción política neoyorquina. Elegante en el vestir y dedicado a sus negocios y a la vida cómoda, Arthur prometía lo peor. De todos modos, su desempeño no fue tan malo como se esperaba. Fue hábil en el manejo de sus decisiones. Apoyó tanto la persecución de la corrupción política para castigar a figuras menores como la ley de reforma del servicio civil en la Administración (Pendleton Act) propuesta por los demócratas, luego de perder la elección de 1882. Su imagen, sin embargo, se dañó mucho cuando propuso para la Corte Suprema a su antiguo jefe político, Roscoe Conkling, un viejo líder republicano que había manipulado la corrupción política en New York. Pese a que su pliego fue aprobado por el Senado, Conckling declinó la nominación y prefirió continuar con el lucrativo ejercicio de la profesión de abogado. Véase Reeves (1991).

Luego de Arthur, la presidencia fue ocupada por un demócrata, Grover Cleveland, quien ejerció dos mandatos no consecutivos (1885-1889 y 1893-1897), en medio de los cuales la Casa Blanca fue ocupada otra vez por un republicano, Benjamin Harrison (1889-1893). Cleveland había obtenido reputación de honesto como gobernador de New York y durante sus dos ejercicios intentó restablecer, sin mayor éxito, la autoridad del Ejecutivo. Como consecuencia de ello, sus relaciones con el Congreso no se caracterizaron por la armonía, sino por las constantes fricciones entre los dos poderes, de lo cual da testimonio la gran cantidad de proyectos de ley del Congreso vetados. Véase Jeffers (2000). Harrison -que derrotó a Cleveland en la elección de 1893 y, a su vez, fue derrotado por este en la de 1897 - venía de una familia con una larga tradición cívica, pero agregó poco a su estirpe. Era nieto del presidente William Henry Harrison, que ocupó la Casa Blanca muy brevemente en 1840, pues murió al mes siguiente de haberse hecho cargo, y bisnieto de Benjamin Harrison, signatario de la Declaración de la Independencia. Véase Socolofsky y Spetter (1987).

Esta debilidad ejecutiva, que ya parecía crónica, comenzó a revertirse con William McKinley (1897-1901), bajo cuya presidencia los Estados Unidos libraron con España una breve y exitosa guerra (1898), que les dio como legado el dominio sobre Cuba y Filipinas. Merced a este conflicto, McKinley pudo ejercer los poderes de guerra y contar con el apoyo del Congreso y de la opinión pública en la conducción de la contienda. También se produjo una expansión territorial con la anexión de Hawaii como territorio.

Su asesinato -segundo en la historia norteamericana- dio acceso a Theodore Roosevelt (1901-1909), su vicepresidente. A diferencia de sus predecesores, Roosevelt poseía una vigorosa personalidad que le permitió ejercer una influencia marcada sobre el Congreso. Muy activo tanto en la política exterior como en la doméstica, luchó por controlar el poder de los grandes grupos económicos, fue un precursor en la conservación de los recursos naturales y obtuvo en 1906 el Premio Nobel de la Paz por su mediación en el tratado de paz que concluyó la guerra 
ruso-japonesa. Bajo su administración, además, se iniciaron las obras de construcción del Canal de Panamá. Véanse, entre otros, Miller (1992); Gould (1991).

Su sucesor y heredero político, William Howard Taft (1909-1913), no estaba dotado en cambio del mismo genio. Tuvo, sin embargo, una actuación importante en la aplicación de la legislación antimonopólica, pero su principal objetivo no era la Casa Blanca, sino la presidencia de la Corte Suprema, destino al que finalmente llegó en 1921 de la mano del presidente Warren G. Harding. Naturalmente, en el camino perdió la posibilidad de ser reelegido. Al cabo de su mandato había perdido el apoyo de Roosevelt, su mentor, quien formó una rama disidente entre los republicanos con la cual compitió sin éxito en la carrera presidencial de 1912, junto con el propio Taft y Woodrow Wilson, quien resultó finalmente el ganador.

Así, un nuevo turno en el poder se abrió para el Partido Demócrata. Taft le entregó la presidencia a Wilson (1913-1921), quien se convertiría en uno de los mandatarios más destacados de su país. Este le dio un nuevo empuje a la presidencia y contribuyó a la formación del moderno concepto sobre esta institución. Como profesor universitario, era un estudioso teórico del problema y ya lo había expuesto en dos obras: Congressional Government (1885) y Constitutional Government in the United States (1908). También había propuesto un cambio en las reglas de juego económico a favor de los más débiles en una obra titulada The New Freedom, publicada el mismo año que se hizo cargo de la presidencia. La obra tenía además un subtítulo sugerente: Un llamado a la emancipación de las generosas energías de un pueblo (A call for the emancipation of the generous energies of a people). Llegó al Gobierno en una época de paz y prosperidad, en la cual las condiciones políticas resultaron favorables para el desarrollo de sus ideas sobre el presidente como líder de la acción legislativa, que en la práctica ejerció. Fue el primero de los jefes del Ejecutivo que desarrolló sistemáticamente los poderes legislativos de su función y su influencia quedó marcada en la legislación sobre tarifas, reforma bancaria y represión de los trusts. Luego, la entrada de Estados Unidos en la Primera Guerra Mundial le daría una oportunidad aún más favorable para convertirse en el símbolo de la unidad nacional y depositario de grandes facultades delegadas por el Congreso. De todos modos, el fin de su vida política se vería ensombrecido por la derrota que la oposición republicana le impuso en el Senado al negarse a ratificar el Tratado de Versalles y, con ello, a ingresar en la Sociedad de Naciones, una de sus creaciones más preciadas. El principal biógrafo de Woodrow Wilson es Arthur S. Link, autor de The Papers of Woodrow Wilson (1966-1994), Woodrow Wilson and the Progressive Era (1954) y Woodrow Wilson and a Revolutionary World (1982). 
